University of Louisville

ThinkIR: The University of Louisville's Institutional Repository

Electronic Theses and Dissertations

$5-2021$

\title{
Focal concerns and case advancement in sexual assault cases: a systematic review and meta-analysis.
}

David Stuart Lapsey Jr

University of Louisville

Follow this and additional works at: https://ir.library.louisville.edu/etd

Part of the Courts Commons

\section{Recommended Citation}

Lapsey, David Stuart Jr, "Focal concerns and case advancement in sexual assault cases: a systematic review and meta-analysis." (2021). Electronic Theses and Dissertations. Paper 3631.

https://doi.org/10.18297/etd/3631

This Doctoral Dissertation is brought to you for free and open access by ThinkIR: The University of Louisville's Institutional Repository. It has been accepted for inclusion in Electronic Theses and Dissertations by an authorized administrator of ThinkIR: The University of Louisville's Institutional Repository. This title appears here courtesy of the author, who has retained all other copyrights. For more information, please contact thinkir@louisville.edu. 
FOCAL CONCERNS AND CASE ADVANCEMENT IN SEXUAL ASSAULT CASES:

A SYSTEMATIC REVIEW AND META-ANALYSIS

\author{
By \\ David Stuart Lapsey Jr \\ B.A., Indiana University Southeast, 2015 \\ M.A., University of Lousville, 2017
A Dissertation
Submitted to the Faculty of the
College of Arts and Sciences of the University of Louisville in Partial Fullfillment of the Requirements
for the Degree of \\ Doctor of Philosophy \\ In Criminal Justice \\ Department of Criminal Justice \\ University of Lousville \\ Louisville, Kentucky
}

May 2021 

FOCAL CONCERNS AND CASE ADVANCEMENT IN SEXUAL ASSAULT CASES:

A SYSTEMATIC REVIEW AND META-ANALYSIS

\author{
By \\ David Stuart Lapsey Jr \\ B.A., Indiana University Southeast, 2015 \\ M.A., University of Lousville, 2017 \\ A dissertation approved on \\ April 23 ${ }^{\text {rd }}, 2021$ \\ by the following dissertation committee \\ Dr. Bradley A. Campbell \\ Dr. Gennaro F. Vito \\ Dr. Benjamin W. Fisher \\ Dr. Eryn N. O’Neal
}




\section{DEDICATION}

I am grateful to my family and friends who helped me throughout my academic career, and cannot thank them enough. That said, I would like to dedicate my dissertation and acknowledge some of the many people who helped me during this long journey. First, I want to dedicate this dissertation to my wife, Taylor Lapsey, who has given me endless love and support. She has been my primary motivation throughout this process, and I am very lucky to have married such a wonder person. Next, I would like to acknowledge others who have given me great support and guidance. Specifically, my dad, David Lapsey Sr, who instilled in me hard work and a drive for success at a early age, and inspired me to continue my education and never quit. Additionally, my family members, including my brothers, mom, and in-laws gave me the inspiration and support needed to complete this project. I would also like to thank my friends for always being there during the eleven years required to complete this degree, and making sure I had plenty of fun during the process. You guys know who you are. I would like to give a big shoutout to the professors at UofL and my committee members for teaching me everthing I know and helping make this happen. I am especially thank Dr. Bradley Campbell, who I have worked with since I was a Master's, and who always offers me guidance and advice. I greatly appreciate the time he spent coaching me these years, and will always be grateful for the opportunities he has provided, and helping make this happen. Finally, I would like to thank my cohort and officemates. I am lucky to have shared my experiences with such excellent people. 


\section{ABSTRACT \\ FOCAL CONCERNS AND CASE ADVANCEMENT IN SEXUAL ASSAULT CASES: \\ A SYSTEMATIC REVIEW AND META-ANALYSIS \\ David Stuart Lapsey Jr}

April $23^{\text {rd }}, 2021$

Scholars have frequently used focal concerns to explain case advancement suspect identification, case clearance, and arrest and charge decisions - in sexual assault cases. Indeed, focal concerns has been popularly used to explain prosecutor decision-making and, more recently, it has increasingly been used to explain police decision-making in sexual assault cases. As such, a systematic review and meta-analysis is needed to synthesize and evaluate existing literature. In this study, meta-analysis is used to estimate the overall size, strength, and direction of focal concerns variables on case advancement in sexual assault cases by using police officers' decision to arrest and prosecutors' decision to charge. This evaluation will follow protocols recommended by the Campbell Collaboration of Systematic Reviews to conduct an exhaustive literature search and use meta-analytic techniques to estimate effect sizes. Results from this study will hopefully help inform policy and training by determining factors associated sexual assault case advancement. 


\section{TABLE OF CONTENTS}

\section{PAGE}

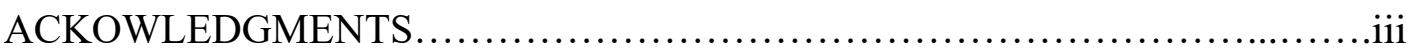

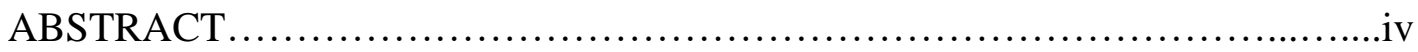

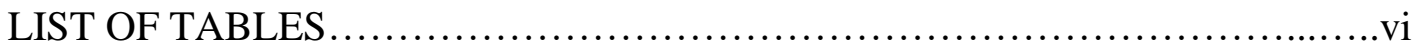

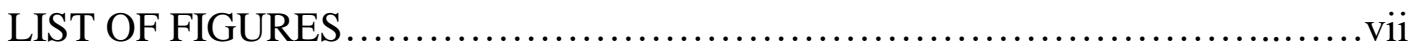

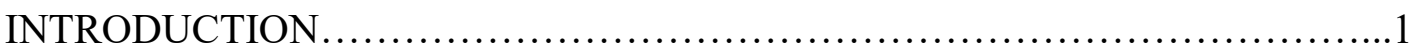

LITERATURE REVIEW ................................................ 9

Rape Myth Acceptance and Sexual Assault Case Advancement..................10

Police and Prosecutor's Decisions in Sexual Assault Cases.......................13

Victim and Case Characteristics and Police Decision-Making...................14

Victim and Case Characteristics and Prosecutor Decision-Making...............24

Focal Concerns and Practitioner Decision-Making ............................35

Focal Concerns and Practitioner Decision-Making in Sexual Assault Cases......40

The Current Study and the Need for a Systematic Review and Meta-Analysis...43

Meta-Analysis....................................................... 45

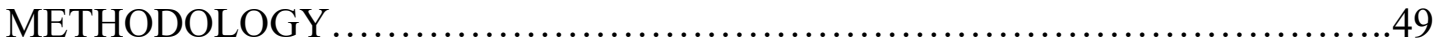

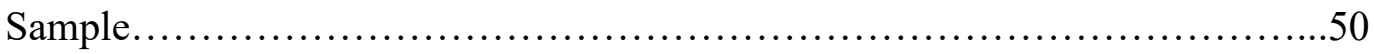

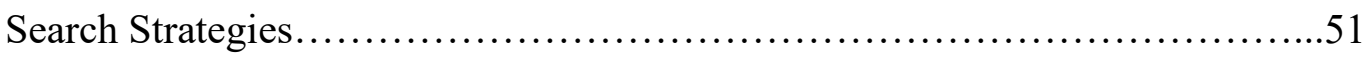

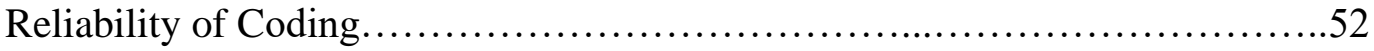

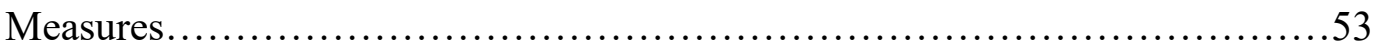




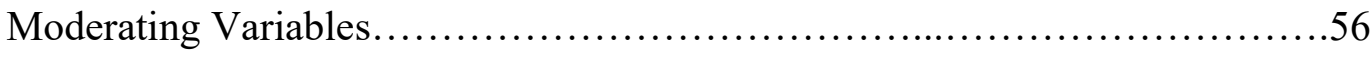

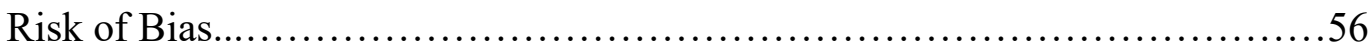

Statistical Dependence Across Studies........................................59

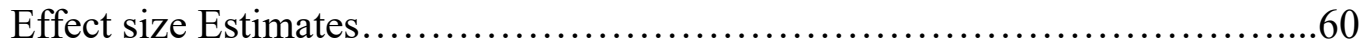

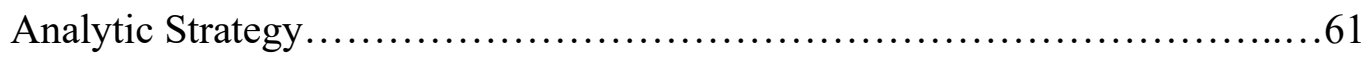

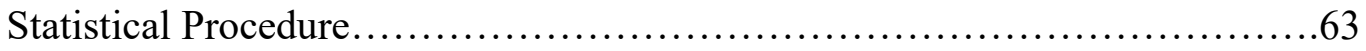

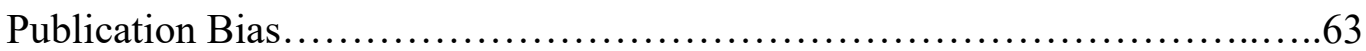

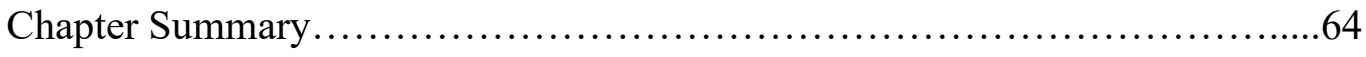

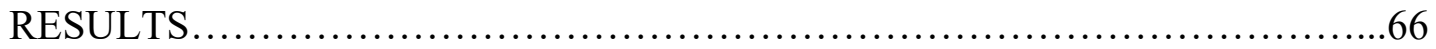

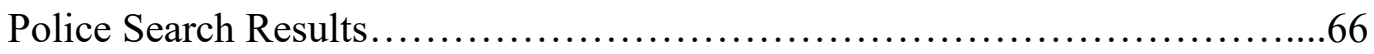

Police Study Sampe Characteristics......................................68

Police Meta-Analysis Results........................................... 70

Police Study Sample Publication Bias.......................................79

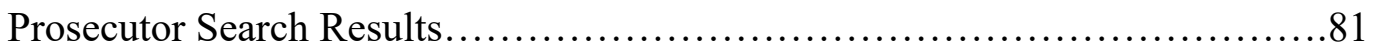

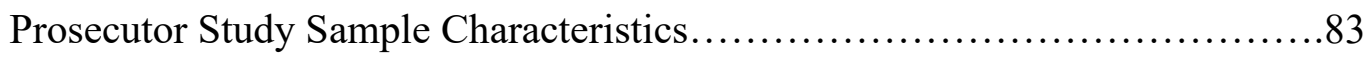

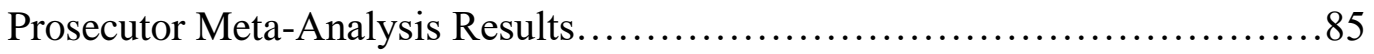

Prosecutor Study Sample Publication Bias..................................93

Police and Prosecutor Meta-Analysis Results.................................96

Police and Prosecutor Study Sample Publiaction Bias..........................105

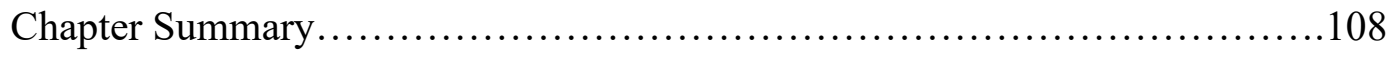

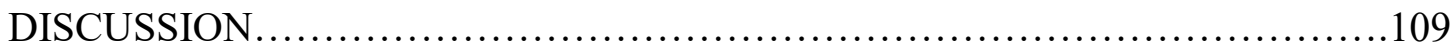

Summary of Current Findings............................................ 112

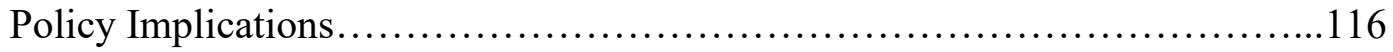


Limitations.................................................... 120

Future Research and Directions........................................ 121

REFERENCES..................................................... 123

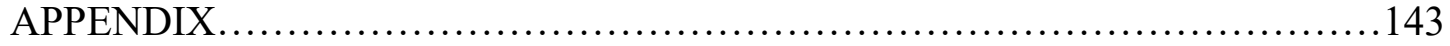

CURRICULUM VITA..................................................... 147 


\section{LIST OF TABLES}

TABLE

PAGE

1. Summary of studies on police decision-making.............................19

2. Summary of studies on prosecutor decision-making .......................29

3. Focal concerns definitions and measurements............................58

4. Police study characteristics.........................................69

5. Multivariate meta-analysis of focal concern estimates for arrest...............72

6. Multivariate meta-analysis for arrest moderated by sample year...............76

7. Multivariate meta-analysis for arrest moderated by sample size...............78

8. Prosecutor study characteristics ........................................ 84

9. Multivariate meta-analysis of focal concern estimates for charging.............86

10. Multivariate meta-analysis for charging moderated by sample year.............90

11. Multivariate meta-analysis for charging moderated by sample size............92

12. Multivariate meta-analysis of focal concern estimates for case advancement.....98

13. Multivariate meta-analysis for case advancement moderated by sample year....102

14. Multivariate meta-analysis for case advancement moderated by sample size.....104 


\section{LIST OF FIGURES}

FIGURE

PAGE

1. Search strategy and results for police studies...........................67

2. Meta-regression plot and $\log$ odds ratio for arrest......................... 74

3. Funnel plot for arrest decision-making ................................ 80

4. Search strategy and results for prosecutor studies.........................82

5. Meta-regression plot and log odds ratio for charging $\ldots \ldots \ldots \ldots \ldots \ldots \ldots \ldots . \ldots 8$

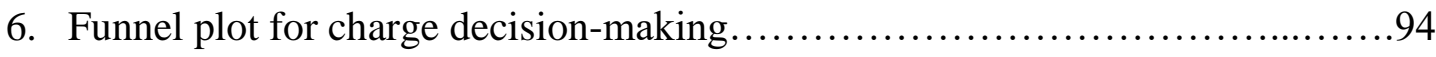

7. Trim-and-fill procedure for charge decision-making $\ldots \ldots \ldots \ldots \ldots \ldots \ldots \ldots \ldots 95$

8. Meta-regression plot and $\log$ odds ratio for case advancement................ 100

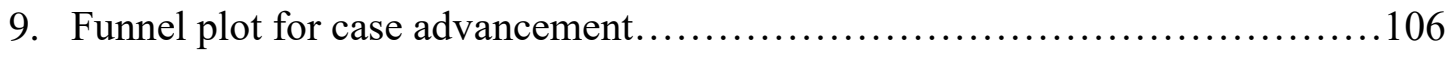

10. Trim-and-fill procedure for case advancement.......................... 107 


\section{CHAPTER 1 \\ INTRODUCTION}

Historically, sexual assault victims have been treated poorly by criminal justice practitioners (Brownmiller, 1975; R. Campbell et al., 2001; Frohman, 1991), and sexual assault cases suffer from high levels of case attrition (Frazier \& Haney, 1996; Gregory \& Lees, 1996). For instance, Morabito and colleagues (2019b) found that only $17.5 \%$ of sexual assault reports resulted in arrest, $72 \%$ of arrests resulted in charges filed, and $12.5 \%$ of total reports resulted in a conviction. Indeed, survivors are often met with skepticism and maltreatment when reporting victimization and throughout the criminal justice process (Estrich, 1987; Frohman, 1991; Maier, 2008). These harms experienced by survivors during the criminal justice process have been termed "secondary victimization" (R. Campbell et al., 2001; Maier, 2008), which has shown to reduce victim engagement with police and prosecutors (R. Campbell, 2008; Frohman, 1991), and can increase long-term post-assault trauma experienced by survivors (Campbell et al., 2001). Additionally, negative perceptions of victims can prevent practitioners from advancing a case and pursuing criminal charges (Galton, 1975; Kelley \& Campbell, 2013; Martin \& Powell, 1994). Finally, when victims are treated poorly by practitioners, it can contribute to the onset of long-term consequences for victims including post-traumatic stress disorder (PTSD), elevated rates of substance abuse, and greater risk of future victimization (R. Campbell, 2012; Marx et al., 2008; Ullman \& Filipas, 2011). 
One contributor to this secondary victimization is police officers' and prosecutors' adherence to rape myths, or stereotypes and misconceptions regarding what practitioners perceive as a "real rape" (Brownmiller, 1975; Estrich, 1987; Lonsway, 2010). Estrich (1987) described practitioners' perception of "real rape" as an offense that included an offender using force during the assault, a victim sustaining injuries, and assaults committed by strangers. If characteristics fail to meet police or prosecutors' expectation of "real rape", then practitioners may blame the victim, question their credibility and the veracity of the allegations, and subsequently the odds of case advancement are diminished (Bouffard, 2000; Campbell, 2008; Estrich, 1987; Jordan, 2004; Lafree, 1981).

For decades, practitioners and advocates have called for improved responses to sexual assault cases (Feilds, 1978), which has moved scholars to conduct studies aimed at identifying correlates of decision-making (Bouffard, 2000; Kestetter, 1990; Kingsworth et al., 1999; Lafree, 1981). Research on this topic has focused primarily on case characteristics (e.g., physical evidence, availability of witnesses, victim injury, suspect weapon use), victim characteristics (e.g., victim-offender relationship, victim race, victim resistance, prompt report of victimization to police), and officers' judgements about victim credibility to determine which characteristics affect case advancement and attrition (Alderden \& Ullman, 2012b; Beichner \& Spohn, 2005; Beichner \& Spohn, 2012; B. Campbell et al., 2015; Kaiser et al., 2017; Morabito et al., 2019a; O’Neal et al., 2019; Scott \& Beaman, 2004; Spohn et al., 2001; Spohn \& Tellis, 2019;).

Findings from this line of research have produced mixed results for both police and prosecutors and report similar factors that impact decision-making. Indeed, studies 
have found physical evidence (Beichner \& Spohn, 2005; Kaiser et al., 2017; Morabito et al., 2019b; Spohn \& Holleran, 2001), witness(es) to the assault (eg., fresh complaint and eye witnesses) (Beichner \& Spohn, 2005; Kaiser et al., 2017; Kingsnorth et al., 1999; Morabito et al., 2019b; Spohn \& Tellis, 2019; O’Neal et al., 2019), victim injury (Frazier \& Haney, 1996; Kerstetter, 1990; Kingsnorth et al., 1999; Morabito et al., 2019b; Spohn \& Tellis, 2019; Venema et al., 2019; Wentz \& Keimig, 2019), and suspect weapon use (Kerstetter, 1990; LaFree, 1981; Morabito et al., 2019b; Spohn et al., 2001; Spohn \& Tellis, 2019; Venema et al., 2019) were significantly correlated with higher likelihood of case advancement. However, some have found physical evidence (O’Neal et al., 2019; Spears \& Spohn, 1997; Spohn et al., 2001), witness(es) to the assault (Alderden \& Ullman, 2012a; Spears \& Spohn, 1997; Wentz, 2019), victim injury (Alderden \& Ullman, 2012; Scott \& Beaman, 2004; Wood et al., 2011), and suspect weapon use (Frazier \& Haney, 1996; Kaiser et al., 2017; Scott \& Beaman, 2004; Ylang \& Holtfreter, 2019) were not significantly correlated with case advancement.

Regarding victim characteristics, studies have found intimate partner relationships (Alderden \& Ullman, 2012b; Kaiser et al., 2017; Morabito et al., 2019b; Spohn et al., 2001), non-stranger relationships (Alderden \& Ullman, 2012b; Morabito et al., 2019b), victim race (e.g, Black, Hispanic, White), (Morabito et al., 2019b; Spohn \& Horney, 1993; Spohn \& Spears, 1996; Venema et al., 2019), victims who physically and/or verbally resisted their assailant (Alderden \& Ullman, 2012ab; Kerstetter, 1990; Morabito et al., 2019; Spohn \& Spears, 1996), and prompt reporting of victimization to police (Beichner \& Spohn, 2005; Kaiser et al., 2017; LaFree, 1981; Morabito et al., 2019b; Spohn \& Tellis, 2019; O’Neal et al., 2019) were significantly correlated with increased 
odds of case advancement. Yet, others did not detect a significant relationship between intimate partner relationships (O’Neal et al., 2019; Spohn \& Tellis, 2019), non-stranger relationships (Beichner \& Spohn, 2005; Kaiser et al., 2017; O’Neal et al., 2019; Spohn \& Tellis, 2019), victim resistance (Kaiser et al., 2017; Scott \& Beaman, 2004; Spears \& Spohn, 1997; Spohn et al., 2001; Spohn \& Holleran, 2001; Spohn \& Tellis, 2019; O’Neal et al., 2019), prompt victim report of victimization to police (Holleran et al., 2010; Tasca et al., 2013; Spears \& Spohn, 1997; Spohn \& Holleran, 2001), and victim race (Bouffard, 2000; Frazier \& Haney, 1996; Kaiser et al., 2017; Spears \& Spohn, 1997; Spohn \& Tellis, 2019) with case advancement.

In addition, scholars have studied practitioner perceptions of victim credibility, an extralegal variable that are variables practitioners should not consider legally relevant rather legal variables that should be legal factors considered in decision-making. Extralegal variables include variables prosecutors and police associated with misconceptions about victims that are not supposed to be considered when making decisions about case outcomes (i.e., actions and behaviors displayed before, during, and after victimization) (B. Campbell et al., 2015; Frohman, 1991), and report mixed findings regarding its impact on practitioner decision-making. For instance, some found when practitioners questioned a victim's credibility (e.g., victim alcohol use prior or during the assault, questions about victim character/reputation, risk taking behavior) the odds of case advancement significantly decreased (Alderden \& Ullman, 2012b; Beichner \& Spohn, 2005, 2012; Kaiser et al., 2017; Morabito et al., 2019a; Spears \& Spohn, 1997). Additionally, some found when practitioners questioned a victim's credibility odds of case advancement significantly decreased (Alderden \& Ullman, 2012a), and others found 
an nonsignificant correlation between victim credibility and case advancement (Holleran et al., 2010; Morabito et al., 2019a; O’Neal et al., 2019; Spohn \& Tellis, 2019).

To explain correlates of practitioner decision-making at multiple stages scholars have relied on the focal concerns perspective (Hartley et al., 2007). Originally developed to explain judicial decisions and sentencing disparities, focal concerns suggests that judges make decisions based on three concepts: (a) the blameworthiness of the offender, (b) the perceived dangerousness of the offender or the need to protect the community, and (c) practical and resources constrains faced by the criminal justice system (Steffensmeier et al., 1998). Additionally, Steffensmeier and colleagues (1998) suggested judges are forced to make decisions with limited time and resources, as well as limited knowledge about an offender's prior criminal history. Thus, judges rely on a "perceptual shorthand" based on extra-legal variables (e.g., offender race, age, gender) to determine their responsibility for the offense and future dangerousness posed by the offender (Steffensmeier et al., 1998). Similar to judges, scholars have found police and prosecutors make decisions based on their perceived likelihood of case advancement. For instance, police make decisions based on whether they believe a prosecutor will accept charges, whereas prosecutors assess a case's "convictability" (e.g., likelihood of conviction) and whether they believe a jury would find the offender guilty at trial (B. Campbell, 2015; Spohn et al., 2014; Tillyer \& Hartley., 2010). If police believe a prosecutor will decline charges or prosecutors believe a juror will find the offender not guilty, then case advancement is unlikely.

The focal concerns framework has been used explain prosecutor decisions in sexual assault cases for dating back to 2001 (Beichner \& Spohn, 2005, 2012; O’Neal \& 
Spohn, 2017; Spohn et al., 2001) and more recently to explain police decision-making (O’Neal \& Spohn, 2017; Spohn \& Tellis, 2019). To explain decision-making in sexual assault cases scholars have used common correlates associated with focal concerns variables (Kaiser et al., 2017; Spohn \& Tellis, 2019; Venema et al., 2019; Wentz 2019, Ylang \& Holtfreter, 2019). Specifically, scholars have used focal concerns to explain sexual assault investigative outcomes and understand how suspect blameworthiness (e.g., victim injury, victim resistance), protection of the community (e.g., suspect used weapon), practical constraints (e.g., physical evidence, witness(es), and perceptual shorthand (e.g., victim-offender relationship, victim credibility) influence practitioner decisions (O’Neal \& Spohn, 2017; Spohn \& Tellis, 2019).

Although many studies use common correlates that measure focal concerns, O'Neal and Spohn (2017) were the first to formally operationalize and measure focal concerns concepts in sexual assault cases. First, they defined offender blameworthiness as offense specific harm to the victim and/or practitioner perception of whether the victim resisted their attacker. Second, protection of the community represents the severity of the assault or the heinousness of the offender's actions. It follows that, if a suspect used a weapon, then the case would be perceived as more heinous and necessitate a greater need to protect the community. Third, practical constraints are factors beyond the control of police and prosecutors, which include physical evidence left during a crime or witnesses corroborating the assault. Fourth, perceptual shorthand are generally extralegal variables practitioners should disregard, often include misconceptions about rape and rape victims, and usually fit with rape myth acceptance. O'Neal and Spohn (2017) provided more standardized measurement of focal concerns to promote consistency across studies and 
thus a path to improve study replication, generalizability, effect size estimate precision, and understanding the relationships between focal concerns and case advancement in sexual assault cases. Though most studies have not specifically operationalized variables into focal concerns concepts, many studies have used measures that tap into O'Neal and Spohn's definitions to explain practitioner decision-making in sex crimes cases (see Kaiser et al., 2015; Spohn \& Tellis, 2019; Venema et al., 2019; Wentz, 2019; Ylang \& Holtfreter, 2019). However, no systematic review has been conducted to evaluate the applicability of the focal concerns perspective to explain case advancement, and there has been no systematic review to determine which characteristics are most important to case advancement.

The literature previously discussed provides an overview on how case characteristics, victim characteristics, and victim credibility influence practitioner decision-making in sexual assault cases. Because of the mixed results detected across studies regarding police and prosecutor decision-making in sexual assault cases, a systematic review and meta-analysis are needed to understand which focal concerns are most important to practitioner decision-making (Cullen, 2005) and how applicable focal concerns is to police and prosecutor decision-making in sexual assault cases. As a result, I aim to differentiate the most important correlates of arrest and charging to inform evidence-based policy. The findings will be useful to inform training for police and prosectors about rape myths and misconceptions, evidence processing, maintaining victim engagement, and interview techniques that can minimize revictimization and potentially increase case advancement and improve system responses to victims of sexual 
assault. Thus, this study seeks to contribute to the sexual assault case processing literature in five primary ways:

1. Produce a systematic meta-analytic literature review of studies assessing correlates of police and prosecutor decision-making in sexual assault cases,

2. Estimate the magnitude and direction of victim and case characteristics on arrest and charge decision-making,

3. Examine whether the effects of victim and case characteristics differ between police and prosecutor decision-making,

4. Combine police and prosecutor decision-making to determine which victim and case characteristics are most important to case advancement, and

5. Assess the applicability of focal concerns to understand case advancement among studies that examined both police and prosecutor decisions in sexual assault cases. 


\section{CHAPTER 2}

\section{LITERATURE REVIEW}

Chapter two reviews the body of literature on police and prosecutor decisionmaking in sexual assault cases, as well as the influence of victim, suspect and case characteristics on the decision-making process. The chapter begins by examining research on rape myths, or stereotypes about rape cases and victims often held by criminal justice practitioners, and how case and victim characteristics can falsely shape practitioners" views and expectations of "real rape" and their perceptions of victim credibility. The chapter then moves into a discussion about the impact of rape myths and practitioner perceptions of victim credibility on police and prosecutor decision-making in sexual assault cases. Next, this chapter reviews findings from research that examined the effects of victim and case characteristics on decision-making through the lens of the focal concerns framework and underscores significant correlates of arrest and charge decisions.

In the end of this chapter, I discuss scholarship on the focal concerns perspective by reviewing the impact of focal concerns concepts on police and prosecutor decisionmaking (e.g., arrest and initial charge) in sexual assault cases. This review focuses on practitioner decisions to arrest, charge, and ultimately advance a case to the next stage in the justice system.

Finally, the chapter moves to a discussion on meta-analysis, and ways in which meta-analysis can address gaps in the research on criminal justice processing of sexual assault cases. Specifically, the chapter stresses the need to "take stock" of the 
applicability of focal concerns to explain case advancement decisions (e.g., arrest and charge decisions) in sexual assault cases. I also explain meta-analytic techniques, their use in criminal justice research, and the ability of meta-analysis to take stock in a large body of research.

\section{Rape Myth Acceptance and Sexual Assault Case Advancement}

For decades, victims of sexual assault have been treated poorly and are met with skepticism by criminal justice practitioners (Brownmiller, 1975; Campbell et al., 2001;

Frohman, 1991), and sexual cases are unlikely to result in arrest or prosecution (Frazier \& Haney, 1996; Gregory \& Lees, 1996). Indeed, studies found that less than $20 \%$ of reported sexual assaults were cleared by arrest (Morabito et al., 2019a; R. Campbell et al., 2014), and that between 18 - $61 \%$ of arrests lead to prosecution (Alderden \& Ullman, 2012b). Research finds these decisions are correlated with practitioners' perceptions and attitudes towards victims, where victims often interact with police and prosecutors who question the veracity of victim allegations (Estrich, 1987). Consequently, practitioners often fail to further process cases or advise the victim to end their pursuit of charges (Galton, 1975; Kelley \& Campbell, 2013; Martin \& Powell, 1994).

These false perceptions and misconceptions - or rape myths - were characterized by Estrich (1987) as perceptions of a "real rape." Specifically, Estrich described that police and prosecutor stereotypes of rape victims often shift blame from suspects towards victims, and that practitioners often believe "true" sexual assaults are ones in which (a) assaults are committed by strangers, (b) victims physically fight back, and (c) victims sustain visible injuries from the attack. Research demonstrates that many police and prosecutors accept this problematic view of sexual assault and follow these false or 
stereotypical characteristics of sexual victimization when making decsions about case advancement (Brownmiller, 1975; Burt, 1980; Estrich, 1987; Lisak et al., 2010; Lonsway, 2010). Thus, if victim allegations do not fit with these stereotypes, then practitioners often question the authenticity of victim allegations (LaFree, 1981). Indeed, studies find practitioners often have predetermined - and false expectations surrounding sexual assault victims. Often these expectations are guided by rape myths, where practitioners expect the offender to use force, the victim to resist the attacker, and the victim to be attacked by a stranger, but are also influenced by factors such as whether the victim consumed alcohol or if police believed the victim had a questionable character or reputation (Beichner \& Spohn, 2012; Bouffard, 2000; R. Campbell, 2008; Estrich, 1987; Kerstetter, 1990; Kingsnorth et al., 1999; Spohn \& Horney, 1993).

Some research finds rape myths and stereotypes also contribute to practitioners' judgements about victim credibility, which studies find is a predictor of practitioner decision-making and case advancement (Beichner \& Spohn, 2005; Spohn et al., 2001; Spohn et al., 2014). Substantial evidence exists to establish a correlation between victim credibility and case advancement (Alderden \& Ullman, 2012a; Beichner \& Spohn, 2005; B. Campbell et al., 2015). Researchers have examined the link between victim credibility and police and/or prosecutorial decision-making (Beichner \& Spohn, 2014; Spohn et al., 2001; Alderden \& Ullman, 2012a; B. Campbell et al., 2015). Victim credibility incorporates factors that impact the believability of victims (Frohman, 1991). Specifically, research shows that practitioner perceptions of a victim's moral character (e.g., history of arrest, substance abuse), alcohol use before or during the assault, and 
engagement in what practitioners perceived as risk taking behavior before the assault (e.g., prostitution, hitchhiking), can all impact victim credibility (Alderden \& Ullman, 2012b; Kaiser et al., 2017; Morabito et al., 2019a; Scott \& Beaman, 2004; Spohn \& Tellis, 2019; O’Neal et al., 2019).

Studies find that practitioner adherence to rape myths plays a role in practitioner decisions to advance cases, as evidence suggests a robust correlation between victim credibility and decisions to arrest or charge in sexual assault cases. For example, studies find that when a suspect used - or threatened to use - a weapon during the attack (Morabito et al., 2019b; Spohn \& Tellis, 2019), the victim verbally or physically resisted (Alderden \& Ullman, 2012ab; Morabito et al., 2019b), or when a victim sustained an injury (Morabito et al., 2019b; Spohn \& Tellis, 2019; Venema et al., 2019) the odds of arrest were substantially increased. Conversely, when police officers take issue with issue with a victim's credibility (e.g., noted a discrepancy in statement, questions about the victim's character/reputation, victim's criminal history) the odds of arrest significantly decrease (Alderden \& Ullman, 2012b; Kaiser et al., 2017; Morabito et al., 2019a).

Scholars have used similar variables to examine prosecutor's decision to charge the second stage of case advancement. Sexual assault cases have higher odds of prosecution when the offender used a weapon (Burt, 1980; Frazier \& Haney, 1996; McGregor et al., 2002), a victim was injured during the attack (Burt, 1980; Frazier \& Haney, 1996; McGregor et al., 2002), or the victim resisted the attacker (Spohn et al., 2001; Spohn \& Horney, 1993; Spohn \& Spears, 1997). Additionally, cases had decreased odds of arrest when prosecutors questioned victim credibility (e.g., victim alcohol use prior or during the assault, questions about victim character/reputation, risk taking 
behavior) (Beichner \& Spohn, 2005; Beichner \& Spohn, 2012; Spears \& Spohn, 1997). In short, research has demonstrated that rape myths often explain police and prosecutor decision-making in sexual assault cases, and the concept of victim credibility is significantly linked to case advancement at both the arrest and charging stages. Accepting these myths are problematic as they often lead to practitioners misinterpreting victim behaviors and faulty decision-making, specifically the belief that "real' victims are emotionally expressive (e.g., crying, visibly distraught) fight back against and sustain injuries during the attack (B. Campbell et al., 2015; R. Campbell 2018). Literature on the neurobiology of trauma counters these rape myths and showed severe trauma has natural adverse effects on memory that hinders the ability to immediately and consistently recount details of victimization (R. Campbell, 2012; Marx et al., 2008). Additionally, although some experience "fight" or "flight" responses to trauma during victimization, research on tonic immobility found some victims subconsciously "freeze" during traumatic events. Severe trauma can trigger a neurobiological response that immobilizes victims and prevents victims from physically stopping the offender, which could explain why many survivors may not resist or suffer visible injuries resulting from the sexual asssault (R. Campbell, 2012; Heidt et al., 2005; Marx et al., 2008).

\section{Police and Prosecutor's Decisions in Sexual Assault Cases}

Prior research has shown that police and prosecutors have broad discretion when making decisions about which cases do - and do not - move forward in the criminal justice process (Frohmann, 1991; Kerstetter, 1990). Because of police officers' role in arrest decision-making, scholars often refer to police as the "gatekeepers" to the criminal justice system, and prosecutor's decision to charge has been referred to as the "gateway 
to justice" (Kerstetter, 1990; Spohn \& Tellis, 2014). Meaning, police use their discretion to establish whether a crime has been committed and then to make an arrest, and prosecutors use their discretion to determine whether to reject or accept initial charges brought by police. In this way, police and prosecutors act as the first and second formal decisions in the criminal justice system. The following sections review studies that have examined correlates of police and prosecutor decision-making.

\section{Victim and Case Characteristics and Police Decision-making}

Police officers' pivotal role as the "gatekeepers" to the criminal justice system, means that they are initial decision-makers in process and determine whether to file a report, make an arrest, or present a case for pre-arrest prosecutorial review. When making decisions to arrest, police weigh a host of victim and case characteristics. Police consider case characteristics such as physical evidence, witness(es), physical injuries, and suspect weapon use to assist in the decision-making process. As previously mentioned, police also rely on "extralegal variables" that stem from their perceptions and stereotypes surrounding "real" sexual assault cases and credible assault victims. These variables often include both victim and case characteristics, such as victim/offender demographics, victim alcohol/substance use, prompt victim report of victimization to police, victim resistance, and victim credibility. As such, to inform the body of literature regarding sexual assault case advancement, scholars have studied the impact of these correlates on police decision-making (Bouffard, 2000; LaFree, 1981; Kaiser et al., 2017), with studies published as early as 1981 (LaFree, 1981). To assess the effects of these variables on decisions to arrest, scholars have relied on samples of sexual assault reports to code for relevant variables correlated with police decision-making (e.g., victim and suspect 
demographics, victim-offender relationship, criminal histories, drug/substance use, evidence availability, weapon used, prompt victim report of victimization to police, victim injury, victim verbal and physical resistance, suspect use of force) (Alderden \& Ullman, 2012ab; Beichner \& Spohn, 2005; Spohn et al., 2001).

Studies examining the relationship between these variables and arrest decisions have produced mixed findings. These mixed findings could be due to different samples (e.g., jurisdictional differences, sample year(s), sample size), measurement differences, or the inclusion of different independent and control variables across studies. In terms of case characteristics, some studies found that the availability of physical evidence (Kaiser et al., 2017; Morabito et al., 2019b), witness(es) to the assault (Kaiser et al., 2017; Morabito et al., 2019b; Spohn \& Tellis, 2019; O’Neal et al., 2019), victim injury (Morabito et al., 2019b; Spohn \& Tellis, 2019; Venema et al., 2019), and suspect weapon use (Morabito et al., 2019b; Spohn \& Tellis, 2019; Venema et al., 2019) were significantly and positively correlated to arrest decision-making. Yet, others found that availability of physical evidence (O'Neal et al., 2019), witness(es) to the assault (Alderden \& Ullman, 2012a; Wentz, 2019), victim injury (Alderden \& Ullman, 2012a; Scott \& Beaman, 2004), and suspect weapon use (Kaiser et al., 2017; Scott \& Beaman, 2004; Ylang \& Holtfreter, 2019) were not significantly correlated with decisions to arrest. A cursory search of literature found studies have been largely consistent concerning the directionality of each effect size, however findings differed on the strength of the relationship between several variables and arrest. For instance, some 
found physical evidence had a very small ${ }^{1}$ to large effect on arrest with odds ratios ranging between 1.43 (Smith, 2005) and 27.11 (Tasca et al., 2013). Results for witness(es) availability had very small to small effects on arrest and odds ratios ranged between 1.17 (Morabito et al., (2019b) and 2.14 (Venema et al., 2019). In regard to victim injury, studies have reported very small to small effects and effect sizes with odds ratios ranging from 1.02 (Kaiser et al., 2017) and 1.84 (Ylang \& Holtfreter, 2019). Similarly, results for suspect weapon use ranged from very small to medium effects on odds of arrest with odds ratios ranging from 1.01 (Ylang \& Holtfreter, 2019) and 2.66 (Scott \& Beaman, 2004).

Studies have also reported mixed findings regarding the impact of victim characteristics on arrest decision-making. For instance, some found intimate partner relationships (Alderden \& Ullman, 2012b; Kaiser et al., 2017; Morabito et al., 2019), non-stranger relationships (Alderden \& Ullman, 2012b; Morabito et al., 2019b), victim race (Morabito et al., 2019; Venema et al., 2019), victim resistance (Alderden \& Ullman, 2012ab; Morabito et al., 2019), and prompt victim reporting of allegations to police (Kaiser et al., 2017; Morabito et al., 2019b; Spohn \& Tellis, 2019; O’Neal et al., 2019) were significantly and positively correlated to arrest decision-making. Additionally, measures of victim credibility (Alderden \& Ullman, 2012b; Kaiser et al., 2017; Morabito et al., 2019b) and victim alcohol consumption (O’Neal et al., 2019; Venema et al., 2019) have been shown to significantly reduce the odds of arrest. Still, others have found insignificant correlations between intimate partner relationships (O’Neal et al., 2019;

\footnotetext{
${ }^{1}$ Effect sizes were described as very small, small, medium, and large using recommendations by Cohen (1988).
} 
Spohn \& Tellis, 2019), non-stranger relationships (Kaiser et al., 2017; O’Neal et al., 2019; Spohn \& Tellis, 2019), victim resistance (Kaiser et al., 2017; Scott \& Beaman, 2004; Spohn \& Tellis, 2019; O’Neal et al., 2019), prompt victim report of victimization to police (Tasca et al., 2013), suspect race (Alderden \& Ullman, 2012a; Kaiser et al., 2017), victim race (Kaiser et al., 2017; Spohn \& Tellis, 2019), victim credibility (Kaiser et al., 2017; Morabito et al., 2019; O’Neal et al., 2019; Spohn \& Tellis, 2019), and victim alcohol consumption (Scott \& Beaman, 2004; Wentz \& Keimig, 2019) to odds of arrest.

Studies produced mixed results concerning both the directionality and strength of effects for the impact of victim related variables on arrest. For instance, some found intimate partner relationships to have very small to large effects on arrest with odds ratios ranging from 1.02 (Wentz, 2019) and 7.1 (Scott \& Beaman, 2004). Victim resistance was found to have very small to small effects with odds ratios ranging from 1.01 (Kaiser et al., 2017) and 1.75 (Scott \& Beaman, 2004). Most studies found prompt report was positively correlated with arrest and had very small to small effects with odds ratios ranging between 1.25 (Venema et al., 2019) and 1.9 (Kaiser et al., 2017), although one study found a large negative correlation with an odds ratio of .10 (Tasca et al., 2013). In regard to victim race, the relationship between non-white victims and arrest had very small to small effects on arrest and odds ratios ranged from 1.11 (Kaiser et al., 2017) and 1.7 (Ylang \& Holtfretter, 2019). Finally, research found victim credibility was both negatively correlated and positively correlated with arrest and effect sizes ranged from small to large. For example, some studies have shown that victim credibility decreased the likelihood of arrest and had very small to small effects on arrest with odds ratios ranging from .59 (Venema et al., 2019) and .81 (Smith, 2005). Conversely, others found 
that victim credibility variables had very small to small effcts on arrest arrest with odds ratios ranging from 1.13 (Tasca et al., 2013) to 2.25 (Alderden \& Ullman, 2012ab). Results showed victim alcohol consumption was negatively correlated with arrest and had very small to small to robust effects and odds ratios ranged from .49 (Ylang \& Holtfretter, 2019) and .81 (Smith, 2005).

As Table 1 demonstrates, the body of research is mixed regarding which correlates are most important to police decision-making in sexual assaults cases. However, studies appear to show that officers and prosecutors do weigh a host of victim and case characteristics when determining to arrest. Although evidence suggest officers rely heavily on case related factors (e.g., witness(es), physical evidence) when processing a case, evidence also suggests officers also rely on stereotypes and myths that influence perceptions about the case and victim's credibility (e.g., victim resistance, victim alcohol consumption, victim moral character/reputation). Moreover, Martin and Powell (1994) reported police are more likely to process cases in which they believe the case is "winnable" and the prosecutor will file charges. As found with prosecutors (Albonetti, 1986), police use extralegal variables to make decisions in the absences of legally relevant factors to eliminate potential uncertainty during arrest decision-making and increase the likelihood prosecutors accept charges. For instance, qualitative research shows investigators use factors such as victim behavior, moral character, substance abuse, and statement consistency when assessing victim credibility, which substantially influence officers' decisions to arrest or present a case to prosecutors (B. Campbell et al., 2015; Spohn \& Tellis, 2014). 
Table 1. Summary of studies on police decision-making

\begin{tabular}{|c|c|c|c|c|}
\hline Study & Sample & Case Outcomes & $\begin{array}{c}\text { Significant Arrest } \\
\text { Predictors }\end{array}$ & $\begin{array}{c}\text { Nonsignificant } \\
\text { Arrest Predictors }\end{array}$ \\
\hline $\begin{array}{l}\text { Alderden \& } \\
\text { Ullman } \\
(2012 \mathrm{a})\end{array}$ & $\begin{array}{c}\text { Large } \\
\text { midwestern } \\
\text { PD, } 2003\end{array}$ & $\begin{array}{l}\text { Arrest, founded, } \\
\text { present to } \\
\text { prosecutor, } \\
\text { charged }\end{array}$ & $\begin{array}{l}\text { Discrepancy } \\
\text { noted, resistance } \\
\text { noted, victim } \\
\text { unwilling to } \\
\text { cooperate }\end{array}$ & $\begin{array}{l}\text { Suspect race, } \\
\text { witness present, } \\
\text { rape kit collected, } \\
\text { discrepancy, } \\
\text { victim injured }\end{array}$ \\
\hline $\begin{array}{l}\text { Alderden \& } \\
\text { Ullman } \\
(2012 \mathrm{~b})\end{array}$ & $\begin{array}{c}\text { Large } \\
\text { midwestern } \\
\text { PD, } 2003\end{array}$ & Arrest & $\begin{array}{l}\text { Detective gender, } \\
\text { resistance, rape } \\
\text { kit collected, } \\
\text { victim character, } \\
\text { nonstranger, } \\
\text { intimate partner }\end{array}$ & \\
\hline $\begin{array}{l}\text { Bouffard } \\
(2000)\end{array}$ & $\begin{array}{l}\text { Urban/Sub } \\
\text { urban, } \\
2005\end{array}$ & $\begin{array}{l}\text { Arrest, closed } \\
\text { victim } \\
\text { unwilling to } \\
\text { cooperate, } \\
\text { prosecutor } \\
\text { declined, open, } \\
\text { unfounded }\end{array}$ & $\begin{array}{c}\text { Physical } \\
\text { description scale, } \\
\text { prior relationship, } \\
\text { sexual assault } \\
\text { exam, } \\
\text { credibility/serious } \\
\text { ness }\end{array}$ & $\begin{array}{c}\text { White } \\
\text { victim/African } \\
\text { American } \\
\text { suspect, legal } \\
\text { definition of rape, } \\
\text { victim's age }\end{array}$ \\
\hline $\begin{array}{l}\text { Kaiser et al. } \\
(2017)\end{array}$ & $\begin{array}{l}\text { LAPD/LA } \\
\text { SD, } 2008\end{array}$ & $\begin{array}{l}\text { Arrest, victim } \\
\text { cooperation at } \\
\text { reporting, } \\
\text { cooperation at } \\
\text { investigation, } \\
\text { cooperation at } \\
\text { arrest }\end{array}$ & $\begin{array}{l}\text { Attempted rape, } \\
\text { sexual battery, } \\
\text { more than one } \\
\text { victim, credibility } \\
\text { questioned, } \\
\text { number of victim } \\
\text { interviews, } \\
\text { suspect intimate } \\
\text { partner, evidence } \\
\text { strength, number } \\
\text { of witnesses, } \\
\text { suspect fled, } \\
\text { prompt reporting, } \\
\text { suspect ID'd by } \\
\text { victim }\end{array}$ & $\begin{array}{l}\text { Victim injury, } \\
\text { other sex offense, } \\
\text { weapon used, } \\
\text { threat made, more } \\
\text { than one suspect, } \\
\text { victim risk taking, } \\
\text { character issues, } \\
\text { suspect } \\
\text { nonstranger, } \\
\text { crime not } \\
\text { reported by } \\
\text { victim, victim } \\
\text { resistance, victim } \\
\text { or suspect black } \\
\text { and Hispanic, } \\
\text { victim and } \\
\text { suspect age }\end{array}$ \\
\hline $\begin{array}{l}\text { Morabito et } \\
\text { al. } \\
(2019 b)\end{array}$ & $\begin{array}{l}\text { Urban, } \\
\text { suburban, } \\
\text { \& rural, } \\
\text { 2008-2010 }\end{array}$ & $\begin{array}{l}\text { Arrest, unfound, } \\
\text { exceptional } \\
\text { clearance, } \\
\text { charges filed, }\end{array}$ & $\begin{array}{l}\text { Black victim, } \\
\text { nonstranger, } \\
\text { intimate partner, } \\
\text { questions about } \\
\text { moral character/ } \\
\text { reputation, }\end{array}$ & $\begin{array}{c}\text { Victim age, } \\
\text { Hispanic/other } \\
\text { victim, risk- } \\
\text { taking behavior, } \\
\text { suspect physically } \\
\text { assaulted victim, }\end{array}$ \\
\hline
\end{tabular}


Table 1. (continued). Summary of studies on police decision-making

\begin{tabular}{|c|c|c|c|c|}
\hline Study & Sample & Case Outcomes & $\begin{array}{c}\text { Significant Arrest } \\
\text { Predictors }\end{array}$ & $\begin{array}{l}\text { Nonsignificant } \\
\text { Arrest Predictors }\end{array}$ \\
\hline & & $\begin{array}{c}\text { guilty } \\
\text { conviction }\end{array}$ & $\begin{array}{l}\text { victim mental } \\
\text { illness, motive to } \\
\text { lie, victim doesn't } \\
\text { recall being } \\
\text { assaulted, suspect } \\
\text { used weapon, } \\
\text { victim injured, } \\
\text { verbal and } \\
\text { physical } \\
\text { resistance, prompt } \\
\text { report, } \\
\text { witness(es), } \\
\text { victim } \\
\text { cooperation in } \\
\text { investigation, } \\
\text { physical evidence }\end{array}$ & $\begin{array}{c}\text { verbal resistance, } \\
\text { physical } \\
\text { resistance }\end{array}$ \\
\hline $\begin{array}{l}\text { O’Neal et } \\
\text { al. } \\
(2019)\end{array}$ & $\begin{array}{l}\text { LAPD/LA } \\
\text { SD, } 2008\end{array}$ & Arrest & $\begin{array}{c}\text { Suspect } \\
\text { black/victim } \\
\text { Hispanic, victim } \\
\text { consumed } \\
\text { alcohol, suspect } \\
\text { interviewed, } \\
\text { victim } \\
\text { cooperated, } \\
\text { witness(es), } \\
\text { prompt report, } \\
\text { victim physically } \\
\text { assaulted }\end{array}$ & $\begin{array}{c}\text { Suspect } \\
\text { black/victim } \\
\text { white, suspect } \\
\text { black/victim } \\
\text { Hispanic, suspect } \\
\text { black/ victim } \\
\text { white, suspect } \\
\text { Hispanic/victim } \\
\text { black, suspect } \\
\text { Hispanic/victim } \\
\text { Hispanic, suspect } \\
\text { Hispanic/victim } \\
\text { white, suspect } \\
\text { white/victim } \\
\text { white, suspect } \\
\text { white/victim } \\
\text { black, suspect } \\
\text { white/victim } \\
\text { Hispanic, intimate } \\
\text { partner, } \\
\text { nonstranger, } \\
\text { victim age, } \\
\text { suspect age, } \\
\text { victim credibility, } \\
\text { physical evidence } \\
\text { collected, }\end{array}$ \\
\hline
\end{tabular}


Table 1. (continued). Summary of studies on police decision-making

\begin{tabular}{|c|c|c|c|c|}
\hline Study & Sample & Case Outcomes & $\begin{array}{c}\text { Significant Arrest } \\
\text { Predictors }\end{array}$ & $\begin{array}{c}\text { Nonsignificant } \\
\text { Arrest Predictors }\end{array}$ \\
\hline $\begin{array}{l}\text { Scott \& } \\
\text { Beaman } \\
(2004)\end{array}$ & $\begin{array}{l}\text { Western } \\
\text { Canada, } \\
1996\end{array}$ & Arrest & $\begin{array}{c}\text { Suspect } \\
\text { drug/alcohol use, } \\
\text { intimate partner, } \\
\text { completed sexual } \\
\text { assault }\end{array}$ & $\begin{array}{l}\text { aggravated sexual } \\
\text { assault, victim } \\
\text { resistance } \\
\text { Suspect age, } \\
\text { victim age, } \\
\text { suspect race, } \\
\text { victim } \\
\text { drug/alcohol use, } \\
\text { nonstranger, } \\
\text { weapon used, } \\
\text { victim injury, } \\
\text { victim resistance }\end{array}$ \\
\hline $\begin{array}{l}\text { Smith } \\
\text { (2005) }\end{array}$ & $\begin{array}{l}\text { Maryland, } \\
2002-2003\end{array}$ & Arrest & $\begin{array}{l}\text { Evidence scale, } \\
\text { number of } \\
\text { suspects, suspect- } \\
\text { victim } \\
\text { relationship }\end{array}$ & $\begin{array}{l}\text { victim resistance, } \\
\text { force, non-white } \\
\text { suspect/non-white } \\
\text { victim, non-white } \\
\text { suspect/white } \\
\text { victim, white } \\
\text { suspect/non-white } \\
\text { victim, victim } \\
\text { alcohol/drugs, } \\
\text { victim age, } \\
\text { suspect age, } \\
\text { suspect } \\
\text { alcohol/drugs, } \\
\text { victim residence }\end{array}$ \\
\hline $\begin{array}{l}\text { Spohn \& } \\
\text { Tellis } \\
\text { (2019) }\end{array}$ & $\begin{array}{l}\text { LAPD/LA } \\
\text { SD, } 2008\end{array}$ & $\begin{array}{l}\text { Arrest, clearest } \\
\text { by arrest, case } \\
\text { presented to the } \\
\text { DA for charge } \\
\text { evaluation prior } \\
\text { to arrest, case } \\
\text { presented to DA } \\
\text { after arrest and } \\
\text { DA filed } \\
\text { charges, case } \\
\text { presented to DA } \\
\text { before or after } \\
\text { arrest and DA } \\
\text { filed charges }\end{array}$ & $\begin{array}{l}\text { Most serious } \\
\text { charge is rape, } \\
\text { suspect physically } \\
\text { assaulted victim, } \\
\text { suspect used a } \\
\text { weapon, victim } \\
\text { injured, reported } \\
\text { within one hour, } \\
\text { number of } \\
\text { witnesses, victim } \\
\text { cooperated, } \\
\text { physical evidence }\end{array}$ & $\begin{array}{l}\text { Victim less than } \\
\text { 18, victim black, } \\
\text { victim Hispanic, } \\
\text { nonstranger, } \\
\text { intimate partner, } \\
\text { risky behavior, } \\
\text { questions about } \\
\text { character/reputati } \\
\text { on, mental } \\
\text { illness/mental } \\
\text { health issues, } \\
\text { motive to lie, } \\
\text { verbal resistance, } \\
\text { physical } \\
\text { resistance, both } \\
\text { verbal and }\end{array}$ \\
\hline
\end{tabular}


Table 1. (continued). Summary of studies on police decision-making

\begin{tabular}{|c|c|c|c|c|}
\hline Study & Sample & Case Outcomes & $\begin{array}{c}\text { Significant Arrest } \\
\text { Predictors }\end{array}$ & $\begin{array}{l}\text { Nonsignificant } \\
\text { Arrest Predictors }\end{array}$ \\
\hline & & & & $\begin{array}{l}\text { physical } \\
\text { resistance }\end{array}$ \\
\hline $\begin{array}{l}\text { Tasca et al. } \\
\text { (2013) }\end{array}$ & $\begin{array}{c}\text { Arizona } \\
\text { City, } 2003\end{array}$ & $\begin{array}{c}\text { Suspect } \\
\text { identified, arrest }\end{array}$ & $\begin{array}{l}\text { Strangers, } \\
\text { forensic evidence } \\
\text { available, victim } \\
\text { made prompt } \\
\text { report, victim } \\
\text { lacked credibility, }\end{array}$ & $\begin{array}{c}\text { Victim history of } \\
\text { drug use }\end{array}$ \\
\hline $\begin{array}{l}\text { Venema } \\
\text { et al. } \\
\text { (2019) }\end{array}$ & $\begin{array}{c}\text { Midwester } \\
\text { n PD, } \\
1999-2014\end{array}$ & $\begin{array}{l}\text { Unfounded, } \\
\text { cleared, } \\
\text { exceptionally } \\
\text { cleared, arrest, } \\
\text { exceptional } \\
\text { cleared: refused } \\
\text { to prosecute }\end{array}$ & $\begin{array}{l}\text { Reported within } \\
\text { 72hrs, detective } \\
\text { male, detective } \\
\text { age, victim } \\
\text { Hispanic, victim } \\
\text { drinking, victim } \\
\text { injury, weapon } \\
\text { use, witness, } \\
\text { acquaintance, } \\
\text { romantic partner }\end{array}$ & \\
\hline $\begin{array}{l}\text { Wentz } \\
(2019)\end{array}$ & $\begin{array}{l}\text { Midwester } \\
\text { n PD, } \\
2000-2010\end{array}$ & $\begin{array}{c}\text { Congruent } \\
\text { charging } \\
\text { decisions, arrest }\end{array}$ & $\begin{array}{l}\text { Suspect age, } \\
\text { physical/forensic } \\
\text { evidence, rape kit, } \\
\text { victim injured, } \\
\text { suspect used } \\
\text { weapon, reported } \\
\text { within } 24 \mathrm{hrs,}\end{array}$ & $\begin{array}{l}\text { Victim age, } \\
\text { suspect white, } \\
\text { witness present, } \\
\text { victim physically } \\
\text { resisted, risky } \\
\text { behavior, intimate } \\
\text { partner, } \\
\text { acquaintance }\end{array}$ \\
\hline $\begin{array}{l}\text { Wentz \& } \\
\text { Keimig } \\
\text { (2019) }\end{array}$ & $\begin{array}{l}\text { Midwester } \\
\text { n PD, } \\
2000-2010\end{array}$ & $\begin{array}{l}\text { Arrest, forward } \\
\text { case to } \\
\text { prosecution }\end{array}$ & $\begin{array}{c}\text { Victim } \\
\text { cooperation, } \\
\text { evidence, weapon } \\
\text { use, victim injury, } \\
\text { time to report }\end{array}$ & $\begin{array}{l}\text { Victim alcohol } \\
\text { use, relationship }\end{array}$ \\
\hline $\begin{array}{l}\text { Ylang \& } \\
\text { Holtfreter } \\
(2019)\end{array}$ & $\begin{array}{l}\text { LAPD/LA } \\
\text { SD, 1982- } \\
\quad 2012\end{array}$ & Arrest, & $\begin{array}{l}\text { Offender stranger, } \\
\text { victim suffered } \\
\text { violence, victim } \\
\text { used } \\
\text { alcohol/drugs }\end{array}$ & $\begin{array}{l}\text { Victim age, } \\
\text { victim white, } \\
\text { offender non- } \\
\text { white, offender } \\
\text { age, offender } \\
\text { non-white, white } \\
\text { offender/white } \\
\text { victim, non-white } \\
\text { offender/non- } \\
\text { white }\end{array}$ \\
\hline
\end{tabular}


Table 1. (continued). Summary of studies on police decision-making

\begin{tabular}{|c|c|c|c|c|}
\hline Study & Sample & Case Outcomes & $\begin{array}{c}\text { Significant Arrest } \\
\text { Predictors } \\
\end{array}$ & $\begin{array}{c}\text { Nonsignificant } \\
\text { Arrest Predictors }\end{array}$ \\
\hline & & & & $\begin{array}{l}\text { victim, non-white } \\
\text { offender/white } \\
\text { victim, multiple } \\
\text { offenders, SAK } \\
\text { submitted for } \\
\text { testing, weapon } \\
\text { used in assault, } \\
\text { victim had sex } \\
\text { post-assault }\end{array}$ \\
\hline
\end{tabular}




\section{Victim and Case Characteristics and Prosecutor Decision-making}

Because prosecutors determine whether a case enters the courts, the decision to charge has been termed the "gateway to justice" (Kerstetter, 1990). Like police,

prosecutors evaluate a host of victim and case characteristics during the decision-making process (Albonetti, 1986; Spohn et al., 2001). To make sense of these decisions, Frohmann (1997) developed the downstream orientation framework which argued prosecutors consider characteristics to determine the "convictability" of a case and by taking into account how jurors and the defense attorneys may respond to a case. In line with the downstream orientation of justice, prosecutors will advance cases when they believe a guilty verdict at trial is likely, whereas cases they consider weak or unlikely to win are dropped. Perceptions of case convictability are guided by the presence of case characteristics such as physical evidence, witness(es), physical injuries, and suspect weapon use when making their decisions. In addition, prosecutors are influenced by victim characteristics, such as victim/offender demographics, victim alcohol/substance use, prompt victim report of victimization to police, and victim resistance, and perceived victim credibility. To understand how prosecutors screen cases to improve the odds of case advancement, scholars have examined the correlation between these characteristics and charge decision-making (Albonetti, 1986; Frohmann, 1991, 1997). To research this area, scholars rely on samples of sexual assault reports to review case files and code for prosecutor decision-making correlates (e.g., victim and suspect demographics, victimoffender relationship, criminal histories, drug/substance use, evidence availability, weapon used, prompt victim report of victimization to police, victim injury, victim verbal and physical resistance, suspect use of force). 
Similar to police decision-making studies of which case, victim, and suspect characteristics influence prosecutor decisions to charge have also produced mixed results. As previously mentioned, mixed findings could potentially be artifacts of different samples (e.g., geographics location, sample year(s), sample size), measurement differences, or different predictors or control variables used in statistical models. For case characteristics, studies have found physical evidence (Beichner \& Spohn, 2005; Spohn \& Holleran, 2001), witness(es) to the assault (Beichner \& Spohn, 2005; Kingsnorth et al., 1999), victim injury (Frazier \& Haney, 1996; Kerstetter, 1990; Kingsnorth et al., 1999; Wentz \& Keimig, 2019), and suspect weapon use (Kerstetter, 1990; LaFree, 1981; Spohn et al., 2001) significantly increase odds a prosecutor will accept charges. However, others have found physical evidence (Spears \& Spohn, 1997; Spohn et al., 2001), witness(es) to the assault (Spears \& Spohn, 1997; Spohn \& Spears, 1996), victim injury (Spears \& Spohn, 1997; Spohn \& Holleran, 2001), and suspect weapon use (Spears \& Spohn, 1997; Spohn \& Holleran, 2001) were unrelated to decisions to levy charges.

Studies produced largely similar results on the directionality of effect sizes, however there were substantive differences regarding the strength of their impact on charging. Studies found physical evidence had very small to small effects on charging and odds ratios ranged from 1.0 (Spohn et al., 2001) and 2.4 (Spohn \& Holleran, 2001). Results showed witness(es) availability had very small to large effects on charging and odds ratios ranged from 1.15 (Spohn \& Spears, 1996) and 9.43 (Wentz \& Keimig, 2019). Victim injury had very small to large effects and odds ratios ranged from 1.15 (Wentz \& Keimig, 2019) and 8.81 (Alderden \& Ullman, 2012a). Many studies found suspect weapon use had a very small to large positive correlation to arrest and odds ratios ranged 
from 1.3 (Kingsworth et al., 1999) and 5.78 (Holleran et al., 2010), although Spears and Spohn (1997) reported a very small negative correlation to arrest and an odds ratio of .73.

In respect to victim characteristics, findings also appear mixed across studies. For instance, some researchers find intimate partner relationships (Spohn et al., 2001), nonstranger relationships (Beichner \& Spohn, 2005), victim race (Spohn \& Horney, 1993; Spohn \& Spears, 1996), victim resistance (Kerstetter, 1990; Spohn \& Spears, 1996), and prompt victim report of victimization to police (Beichner \& Spohn, 2005; LaFree, 1981,) are significantly and positively correlated to odds of charging. In addition, measures of victim credibility (Beichner \& Spohn, 2005; Spohn et al., 2001; Spears \& Spohn, 1997; Spohn \& Spears, 1996) and victim alcohol consumption (Chandler \& Torney, 1981; Kerstetter, 1990) have been shown to significantly reduce the odds of charge. Conversely, others have found stranger cases are more likely to be charged (Kerstetter, 1990; Weninger, 1978), while victim race (Bouffard, 2000; Frazier \& Haney, 1996; Spears \& Spohn, 1997), victim resistance (Spohn et al., 2001; Spohn \& Holleran, 2001; Spears \& Spohn, 1997), prompt victim report of victimization to police (Holleran et al., 2010; Spears \& Spohn, 1997; Spohn \& Holleran, 2001), and measures of victim credibility (Holleran et al., 2010; Spears \& Spohn, 1997) are insignificantly related to odds of charging.

Research showed intimate partner relationships have small to large effects and odds ratios ranged from 1.09 (Holleran et al., 2010) and 7.28 (Spohn et al., 2001). Nonstranger relationships had both a very small negative effect and a very small positive effect on charging and odds ratios ranged from .76 (Spears \& Spohn, 1997) and 1.42 (Spohn \& Spears, 1996). Studies found that non-white victims were negatively correlated 
with charging, had very small to small effects, and odds ratios ranged from .53 (Spears \& Spohn, 1997) and .75 (Spohn et al., 2001). Studies showed victim resistance had very small to small effects on charging and odds ratios ranged from .57 (Spohn et al., 2001) and .95 (Spohn \& Holleran, 2001). Many studies showed prompt report time had small to medium effects and increased odds of arrest with odds ratios ranging from 1.49 (Spohn \& Holleran, 2001) and 3.06 (Kingsworth et al., 1999), although a single study reported a very small negative correlation with arrest and odds ratio of .73 (Holleran et al., 2010). Results showed measures of victim credibility had very small to large effects on charging and odds ratios ranged from 1.27 (Beichner \& Spohn, 2005) and 8.81 (Holleran et al., 2010). Victim alcohol use had small to medium effects on charging and odds rations ranged from .38 (Wentz \& Keimig, 2019) and .57 (Spohn \& Beichner, 2012).

As Table 2 shows, this line of research has mixed findings concerning variables significantly related to the odds a case will result in prosecutors accepting charges. Results show case characteristics play a role in prosecutor decision-making (e.g., physical evidence, witness(es), weapon use) and that victim characteristics and extralegal variables are correlated to charging decisions. Indeed, results showed measures associated with stereotypes and rape myths (victim credibility, victim resistance, victim reputation/moral character) influenced prosecutor's decision to charge. Evidence suggests prosecutors assess characteristics indicative of a "winnable" or convictable case when weighing their decision to charge (Albonetti, 1986; Spohn \& Holleran, 2001; Sphn et al., 2001). Thus, prosecutors often use extralegal factors help reduce uncertainty during the decision-making process (Albonetti, 1986) - especially with little evidence - and influence potential case advancement. These findings align with Frohmann's (1991) 
conclusion that prosecutors accept cases they view as winnable and reject difficult cases to maintain high convictions and a strong record. 
Table $^{2}$ 2. Summary of studies on prosecutor decision-making

\begin{tabular}{|c|c|c|c|c|}
\hline Study & Sample & $\begin{array}{c}\text { Case } \\
\text { Outcome } \\
\text { s }\end{array}$ & $\begin{array}{c}\text { Significant } \\
\text { Charge Predictors }\end{array}$ & $\begin{array}{c}\text { Insignificant Charging } \\
\text { Predictors }\end{array}$ \\
\hline $\begin{array}{l}\text { Beichner } \\
{ }^{3} \& \text { Spohn } \\
(2005)\end{array}$ & $\begin{array}{c}\text { Kansas } \\
\text { City, } \\
\text { Missouri } \\
(1996-98) \& \\
\text { Miami } \\
\text { Dade, FL } \\
\text { (1997) }\end{array}$ & Charge & $\begin{array}{l}\text { Risk-taking, } \\
\text { moral character, } \\
\text { prompt report, } \\
\text { suspect age, } \\
\text { victim injury, } \\
\text { physical } \\
\text { evidence, witness }\end{array}$ & $\begin{array}{l}\text { White suspect/white } \\
\text { victim, black } \\
\text { suspect/black victim, } \\
\text { victim age, } \\
\text { Acquaintance/relative, } \\
\text { IP, suspect used } \\
\text { gun/knife }\end{array}$ \\
\hline $\begin{array}{l}\text { Frazier \& } \\
\text { Haney } \\
(1996)\end{array}$ & $\begin{array}{c}\text { Midwestern } \\
\text { Metropolita } \\
\text { n (1990- } \\
1994)\end{array}$ & $\begin{array}{l}\text { Suspects } \\
\text { questione } \\
\text { d, } \\
\text { charged }\end{array}$ & Injuries, threats & $\begin{array}{l}\text { Witness, verbal } \\
\text { resistance, physical } \\
\text { resistance, victim } \\
\text { alcohol/drug, } \\
\text { acquaintance rape, } \\
\text { weapon, penetration, } \\
\text { gang rape, white } \\
\text { victim, white assailant }\end{array}$ \\
\hline $\begin{array}{l}\text { Holleran } \\
\text { et al. } \\
(2010)\end{array}$ & $\begin{array}{c}\text { Kansas } \\
\text { City, MI } \\
\text { (1996-98), } \\
\text { Philadelphia } \\
\text {, PA (1997) }\end{array}$ & Charge & $\begin{array}{c}\text { Kansas City: } \\
\text { Physical } \\
\text { evidence, } \\
\text { intimate partner, } \\
\text { Acquaintance, } \\
\text { suspect used } \\
\text { gun/knife, victim } \\
\text { major injuries, } \\
\text { risky behavior; } \\
\text { Philadelphia: } \\
\text { physical } \\
\text { evidence, } \\
\text { Acquaintance, } \\
\text { multiple } \\
\text { offenders }\end{array}$ & $\begin{array}{l}\text { Kansas City: multiple } \\
\text { offenders, Moral } \\
\text { character, victim } \\
\text { resisted, prompt report, } \\
\text { victim age, suspect age, } \\
\text { victim white, suspect } \\
\text { white; Philadelphia: } \\
\text { intimate partner, suspect } \\
\text { used gun/knife, victim } \\
\text { major injuries, risky } \\
\text { behavior, moral } \\
\text { character, victim } \\
\text { resisted, prompt report, } \\
\text { victim age, suspect age, } \\
\text { victim white, suspect } \\
\text { white, prior felony } \\
\text { convictions }\end{array}$ \\
\hline $\begin{array}{l}\text { Kingswor } \\
\text { th et al. } \\
(1999)\end{array}$ & $\begin{array}{l}\text { Sacramento } \\
\text { County, CA } \\
(1992-94)\end{array}$ & Charge & $\begin{array}{l}\text { Victim injury, } \\
\text { incriminating } \\
\text { remarks, suspect } \\
\text { arrest(s), report } \\
\text { less }\end{array}$ & $\begin{array}{l}\text { Gun/knife used, } \\
\text { nonstranger, suspect } \\
\text { prior felonies, } \\
\text { accomplices, negative }\end{array}$ \\
\hline
\end{tabular}

${ }^{2}$ Lafree (1989) used an interval variable for the dependent variable charge, which used a seriousness score that excluded charge rejected.

${ }^{3}$ Pooled from both jurisdictions. 
Table 2. (continued). Summary of studies on prosecutor decision-making

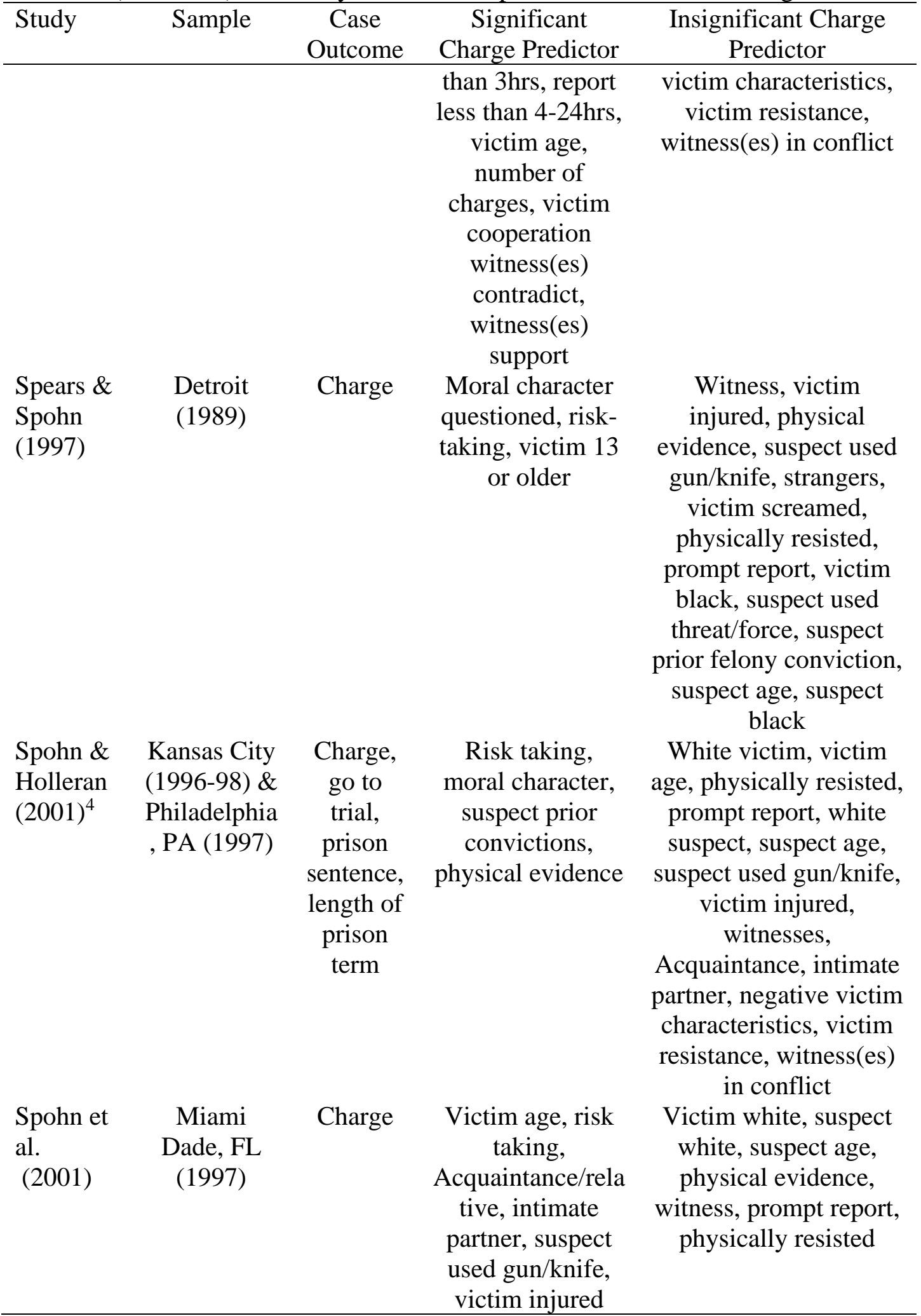

${ }^{4}$ Pooled from both jurisdictions 
Table 2. (continued). Summary of studies on prosecutor decision-making

\begin{tabular}{|c|c|c|c|c|}
\hline Study & Sample & $\begin{array}{c}\text { Case } \\
\text { Outcome }\end{array}$ & $\begin{array}{c}\text { Significant } \\
\text { Charge Predictors }\end{array}$ & $\begin{array}{l}\text { Insignificant Charge } \\
\text { Predictors }\end{array}$ \\
\hline $\begin{array}{l}\text { Spohn \& } \\
\text { Spears } \\
\text { (1996) }\end{array}$ & $\begin{array}{c}\text { Detroit } \\
(1970-84)\end{array}$ & $\begin{array}{c}\text { All } \\
\text { charges } \\
\text { dismissed } \\
, \\
\text { convicted } \\
, \\
\text { incarcerat } \\
\text { ed, } \\
\text { sentence } \\
\text { length }\end{array}$ & $\begin{array}{c}\text { Black } \\
\text { offender/black } \\
\text { victim, white } \\
\text { offender/white } \\
\text { victim, risk } \\
\text { taking, screamed } \\
\text { during attack, } \\
\text { mean no. of } \\
\text { charges, }\end{array}$ & $\begin{array}{l}\text { Offender age, prior } \\
\text { felony convictions, } \\
\text { victim age, strangers, } \\
\text { prior sexual } \\
\text { relationship, physically } \\
\text { resisted, prompt report, } \\
\text { charge with forcible } \\
\text { rape, vaginal } \\
\text { penetration, more than } \\
\text { one offender, more } \\
\text { than one victim, } \\
\text { offender used } \\
\text { gun/knife, victim } \\
\text { injured, witness, } \\
\text { physical evidence }\end{array}$ \\
\hline $\begin{array}{l}\text { Spohn \& } \\
\text { Tellis } \\
\text { (2019) }\end{array}$ & $\begin{array}{c}\text { LAPD/LAS } \\
\text { D (2008) }\end{array}$ & $\begin{array}{c}\text { Arrest, } \\
\text { clearest } \\
\text { by arrest, } \\
\text { case } \\
\text { presented } \\
\text { to the DA } \\
\text { for } \\
\text { charge } \\
\text { evaluatio } \\
\text { n prior to } \\
\text { arrest, } \\
\text { case } \\
\text { presented } \\
\text { to DA } \\
\text { after } \\
\text { arrest and } \\
\text { DA filed } \\
\text { charges, } \\
\text { case } \\
\text { presented } \\
\text { to DA } \\
\text { before or } \\
\text { after } \\
\text { arrest and } \\
\text { DA filed } \\
\text { charges }\end{array}$ & $\begin{array}{l}\text { Victim less than } \\
18, \text { risky } \\
\text { behavior, motive } \\
\text { to lie, most } \\
\text { serious charge is } \\
\text { rape, suspect used } \\
\text { a weapon, victim } \\
\text { reported within } \\
\text { one hour, victim } \\
\text { willing to } \\
\text { cooperate }\end{array}$ & $\begin{array}{l}\text { Victim black, victim } \\
\text { Hispanic, nonstranger, } \\
\text { intimate partner, } \\
\text { questions about moral } \\
\text { character, mental } \\
\text { illness/mental health } \\
\text { issue, suspect } \\
\text { physically assaulted } \\
\text { victim, victim injured, } \\
\text { verbal resistance, } \\
\text { physical resistance, } \\
\text { verbal and physical } \\
\text { resistance, number of } \\
\text { witness, physical } \\
\text { evidence }\end{array}$ \\
\hline
\end{tabular}


Table 2. (continued). Summary of studies on prosecutor decision-making

\begin{tabular}{|c|c|c|c|c|}
\hline Study & Sample & $\begin{array}{c}\text { Case } \\
\text { outcome }\end{array}$ & $\begin{array}{c}\text { Significant } \\
\text { Charge Predictors }\end{array}$ & $\begin{array}{l}\text { Insignificant Charge } \\
\text { Predictors }\end{array}$ \\
\hline $\begin{array}{l}\text { Wood } \\
\text { et al. } \\
(2011)\end{array}$ & $\begin{array}{c}\text { Alaska State } \\
\text { Troopers } \\
(2003-2004)\end{array}$ & $\begin{array}{c}\text { Refer } \\
\text { case for } \\
\text { prosecuti } \\
\text { on, } \\
\text { accept } \\
\text { case for } \\
\text { prosecuti } \\
\text { on }\end{array}$ & $\begin{array}{l}\text { Paraprofessional } \\
\text { responder, } \\
\text { cooperative } \\
\text { victim, reported } \\
\text { within } 24 \mathrm{hrs,}\end{array}$ & $\begin{array}{c}\text { Isolated location, } \\
\text { Alaska Native victim, } \\
\text { witnesses, victim } \\
\text { injury, aggravated } \\
\text { offense, intimate } \\
\text { partner relationship, } \\
\text { victim/drug alcohol use }\end{array}$ \\
\hline
\end{tabular}




\section{Focal Concerns and Practitioner Decision-making}

Despite decades of research on case advancement and attrition in sexual assault cases, and although most criminal justice research on police arrest decision-making and prosecutor charge decision-making has not used theory to guide analyses, some have used the sexual stratification hypothesis and rape culture framework to expain decisionmaking (see Kelley et al., 2000; Spears \& Spohn, 1996; O’Neal et al., 2015). The sexual stratification hypothesis stems from conflict theory and has been applied to the decisionmaking process and responses to victimization to explain racial and ethnic disparities (Tellis \& Spohn, 2008) and the influence of victim-offender relationship (Bachman, 1998; O’Neal et al., 2019). The sexual stratification hypothesis argues those in power control sexual access based on race and ethnicity (Tellis \& Spohn, 2008). It follows, Black and Hispanic men who sexually assault White women are seen by the dominant groups - White men - as distrupting and the power heirachy. Additionally, some researchers have used the rape culture framework to understand social environemnts where sexual violence is tolerated and accepted by people as normal (see Buchwald et al., 1993; O’Neal \& Hayes, 2020). This normalized culture may shape people's views and negatively incluence perceptions about sexual victimization and drive misguided stereotupes about rape victims (Burt, 1980).

That said, however, my review focuses on criminal justice scholarship, which has begun to apply the focal concerns perspective to help explain and understand correlates of decision-making at the arrest and charging stages. Specifically, researchers have used the framework to explain prosecutorial decision-making in sexual assault cases (Beichner \& Spohn, 2012; Spohn et al., 2001), while others have recently expanded the framework 
to explain police decision-making in taser usage (Crow \& Adrion, 2011), time lapses in serving arrest warrants (Johnson et al., 2015), and unfounding cases and identify false reports (Spohn et al., 2014).

The construction of the focal concerns perspective was inspired by previous research by Albonetti (1986, 1987), which argued practitioners make decisions based on a bounded "reality" (Albonetti, 1991, p. 249), specifically when the case lacks physical evidence and practitioners seek to minimize "uncertainty" that surrounds the case. Albonetti (1991) also incorporated work from structural organization theory and argued fully rational decisions are made only when the decision-maker has the "knowledge of all possible alternatives" (p. 248) and stated practitioners make decisions based on "a reality that is the product of habit and social structure" (Albonetti, 1991, p. 249), where judges' sentencing decisions and prosecutors' decisions to charge are guided by characteristics of offenders linked to recidivism (Albonetti, 1986, 1987, 1991). Albonetti argued judges seldom have complete information during the decision-making process and must rely on perceptual shorthand, past experiences, stereotypes, and prejudice from their habits and social structure. For instance, a judge is more likely to issue a longer sentence when an offender had prior arrests, used a weapon, or caused a physical injury.

Following this line of thinking, Steffensmeier et al. (1998) conceptualized the focal concerns framework by expanding Albonetti's work to include concepts that encompassed additional offender and organizational characteristics. Steffensmeier and colleagues' primary goal was to create a theory that could make sense of how judges made sentencing decisions. Accordingly, Steffensmeier and colleagues' original focal concerns framework contains three primary concepts, including (a) culpability and 
offender blameworthiness, (b) the perceived dangerousness of the offender and need for community protection through incapacitation and general deterrence, and (c) practical and resource constraints faced by decision-makers in the criminal justice system (Steffensmeier et al., 1998). In addition, focal concerns argues that judges often have limited knowledge regarding an offender's criminal background, personality, or moral character, and must also make quick and decisive decisions based on limited information and resources (e.g., time, court cost). When time or information is limited to fully inform decisions, judges often use a "perceptual shorthand" based on an evaluation of extralegal variables (e.g., offender race, sex, age) to determine the offender's perceived blameworthiness and threat to society. Based on these concepts, judges make an assessment of how likely an offender is to commit further crimes based on stereotypes concerning "who is dangerous and who is not", while taking into account constraints such as potential strain on correctional facilities, incarceration costs, offender needs, and political implications during decisions (Steffensmeier et al., 1998, p. 767). It is important to stress extralegal charactertistics such as victim race and suspect race are variables that should no be considered during the legal decision-making process. However, research has found these variables may influence decicions (Kelley et al., 2020; Spohn \& Tellis, 2008). For instance, research finds decision-making is often based on the victim-racialethnic dyad, and white victim who assault non-white victims are more likely to receive more lenient treatment and non-white suspects who assault white victims receve harsher treatment (Kelley et al., 2020; O’Neal et al., 2016). In addition, some evidence suggest Black-on-Black sexual assaults may be viewed as less worthy of resources from the lgal system and experience higher case attrition (Kelley et al., 2020) 
Sentencing research using focal concerns has included variables such has race, ethnicity, and criminal history to better understand judges' sentencing decisions (Franklin \& Henry, 2020; Johnson \& Bestinger, 2009; Steffensmeier et al., 1998), and has determined that judges sometimes view specific groups as more dangerous or blameworthy for their crime (Johnson \& DiPietro, 2012). Indeed, studies have shown non-white offenders often receive harsher sentences compared to white offenders (Alvarez \& Bachman, 1996; Franklin, 2013; Franklin \& Henry, 2020; Mitchell, 2005; Ulmer, 2012), and that young, black males are often sentenced the harshest (Spohn \& Holleran, 2001; Steffensmeier et al., 1998). Scholars have also found criminal history and offense severity increase sentencing length imposed by judges (Franklin, 2017; Franklin \& Henry, 2020; Spohn, 2000; Zatz, 2000)

Researchers have furthered the application of focal concerns to other critical decision points in the justice system (Hartley et al., 2007). For instance, Hartley et al. (2007) discussed how previous studies have conceptualized and operationalized focal concerns variables, as well as explored how recent studies have used the framework to explain police and prosecutor decisions. Hartley and colleagues provided clarity to the framework by suggesting specific measures for each concept and ways to improve concept measurement. The authors argued that, in its original form, the focal concerns framework produced "no set of testable propositions; most hypotheses that have been derived from this work have been extended over time" (p. 73) and thus attempted to address shortcomings of focal concerns. Their argument provided several limitations of focal concerns and included suggestions to move focal concerns research forward. First, one shortcoming was that focal concerns lacked established measurements for concepts. 
As such, the authors used factor analysis to statistically examine the relationship between independent variables and determine variables that could be collapsed within a concept. Second, Hartley and colleagues suggested that some variables could be used to measure multiple concepts, such as criminal history, which can be used to explain blameworthiness and the need for protection of the community. Factor analysis helped provide clarity to concept measurement and found criminal history loaded onto the factor protection of the community rather than suspect blameworthiness, and suggested using criminal history to measure protection of the community. Third, Hartley et al. suggested the need to fully operationalize and explore perceptual shorthand and practical constraints. Initially, scholars primarily used Pennsylvania Sentencing Commission data to study sentencing decisions, which lacked variables needed to study perceptual shorthand and practical constraints. Thus, the authors used Federal Sentencing Commission data that allowed for a "fuller conceptualization, operationalization, and thus, a more complete test of the focal concerns perspective" (Hartley et al., 2007, p. 64). In this way, Hartley et al. (2007) helped advance conceptualization and operationalization of focal concerns concepts and to produce a framework for future researchers using the perspective.

Following Hartley and colleagues work, scholars have expanded on focal concerns to explain prosecutor decision-making (Beichner \& Spohn, 2012; Spohn et al., 2001). For example, Spohn et al. (2001) argued when making charging decisions in sexual assault cases, prosecutors and judges weigh similar factors, specifically those related to offense severity, offender's criminal history, and suspect culpability during the decision-making process. It follows that, higher odds of charges exist when factors 
corroborate a victim's claim and indicative of a serious offense. Diverging slightly from Steffensmeier et al. (1998), Spohn and colleagues (2001) argued prosecutors fail to consider the same practical constraints and consequences of judges. Unlike judges, who consider strain on correctional facilities, incarceration costs, offender needs, and political implications during decisions, prosecutors are more focused on a jury finding the defendant guilty (Beichner \& Spohn, 2012; Spohn et al., 2001). As such, prosecutors have relied on a perceptual shorthand based on stereotypes and myths about sexual assault cases and victims, while also attempting to reduce uncertainty regarding case outcomes (Spohn et al., 2001). Included in perceptual shorthand developed by prosecutors are both factors that blame victims (e.g., risk-taking behavior, moral character) and victim characteristics (e.g., prompt reporting of victimization to police, victim resistance) that are perceived to affect juror decision-making.

Scholars that have used focal concerns measures to explain prosecutorial decision-making find support for the framework (Beichner \& Spohn, 2005; Brady \& Reyns, 2020; Holmes \& D’Amato, 2020; Spohn \& Tellis, 2019). For instance, Brady and Reyns (2020) examined prosecutors' charging decisions in stalking cases and found support for protection of the community (e.g., pursued victim in a public location) and practical constraints (e.g., evoked fear in the victim). Their findings revealed that prosecutors were $230 \%$ more likely to charge offenders that pursued victims in public and were $290 \%$ more likely to charge offenders that evoked fear in victims. Additionally, Stemen and Escobar (2018) examined prosecutors' decision to reject charges in 318,000 felony and misdemeanor cases and found support for offender blameworthiness (e.g., offense seriousness, number of charges) and perceptual shorthand (e.g., offender race, 
offender age). The authors found more serious offenses reduced likelihood of charges rejected by 5\% and greater number of charges reduced likelihood of charges rejected by $16 \%$. Offender race also had a statistically significant effect on case dismissal, and case that involved non-white suspects were 3\% less likely to result in the rejection of charges. Specific to sexual assault cases, Beichner and Spohn (2005) found support for offender blameworthiness (e.g., victim injured) and practical constrains (e.g., physical evidence available, witness(s) present) and reported prosecutors were $141 \%$ more likely to charge when a victim was injured, $161 \%$ more likely to charge when physical evidence was available, and $167 \%$ when a witness(es) was present. Spohn \& Tellis (2019) found support for protection of the community demonstrating that prosecutors were $220 \%$ more likely to charge when a suspect used a weapon during the incident.

Similar to the application of focal concerns to prosecutorial decisions, recent policing scholars have used the perspective to explain officer decision-making across various outcomes (e.g., search vehicle, use a taser, submit sexual assault kit) (R. Campbell \& Fehler-Cabral, 2018; Crow \& Adrion, 2011; Higgins et al., 2012; Ishoy \& Dabney, 2017; Johnson et al., 2015; Spohn et al., 2014; Tillyer \& Hartley, 2010). Crow and Adrion (2011) used focal concerns to explain officers' decision to use taser in use of force incidents and found evidence that protection of the community (e.g., perceived dangerousness), perceptual shorthand (e.g., suspect sex and race), and practical constraints (e.g., taser policy). After controlling for situational factors and suspect characteristics, the odds of officers using a taser decreased by $60 \%$ in situations involving a suspect who used physical or weapon-related resistance compared to verbal resistance. This provides evidence that officers consider perceived level of dangerousness when met 
with resistance. Officer taser use increased by $99 \%$ for non-white suspects and 362\% for male suspects. Lastly, new agency policy (e.g., taser training) reduced taser usage by nearly $60 \%$. Higgins and colleagues (2012) also used focal concerns to explain officers' decision to search a vehicle during a traffic stop and found the decision was strongly and positively correlated with blameworthiness (e.g., contraband in plain view, smelled drug odor). In fact, officers were 56\% more likely to arrest suspects when offender blameworthiness variables were found in a traffic stop.

\section{Focal Concerns and Practitioner Decision-making in sexual assault cases}

Academics have relied on focal concerns to explain practitioner decision-making at multiple stages (e.g., arrest, charging) in sexual assault cases. For nearly 20 years scholars have used the focal concerns perspective to explain prosecutor decision-making in sexual assault cases (Beichner \& Spohn, 2005, 2012; Spohn et al., 2001; Wentz, 2019), and more recently scholars have begun to use focal concerns concepts and variables to study police decision-making in sexual assault cases (Kaiser et al., 2017; Spohn \& Tellis, 2019; Venema et al., 2019; Wentz 2019, Ylang \& Holtfreter, 2019). Regarding sexual assault investigations, scholars have used focal concerns to determine how focal concerns variables influence police decision-making (O’Neal \& Spohn, 2017; Spohn \& Tellis, 2019). Scholars used the focal concerns perspective to describe suspect blameworthiness as harm caused to the victim, protection of the community as the severity or heinousness of the assault, practical constraints as factors beyond the control of practitioners, and perceptual shorthand as extralegal variables practitioners disregard and usually fit with rape myth acceptance. Still, until only recently have scholars operationalized focal concerns variables and addressed measurement deficiencies (Hartley et al., 2007). Thus, I 
adapted work from Tillyer and Hartley (2010) and O’Neal and Spohn (2017) to guide definitions and operationalizations of focal concerns variables and are displayed.

Tillyer and Hartley (2010) first defined suspect blameworthiness as the suspect's level of culpability and seriousness of the crime. Second, protection of the community was defined as protecting the community from repeat offenders. Third, practical constraints was defined as factors that increase the probability of case advancement. Forth, perceptual shorthand was defined as extralegal factors considered during decisionmaking. Additionally, O’Neal and Spohn (2017) were the first to formally operationalize focal concerns variables to explain decision-making in sexual assault cases and operationalized (a) suspect blameworthiness using variables that measured whether the suspect previously sexually assaulted the victim, suspect previously physically assaulted the victim, victim was injured at the time of assault, suspect physically assaulted victim at time of incident, and victim resisted (verbally, physically, or both); (b) ${ }^{5}$ protection of the community was measured by indicated whether the suspect used some type of weapon; (c) practical constraints was captured by indicating whether some physical evidence collected, the suspect was interviewed by police, the victim cooperated with investigation, there was at least one witness to the incident, the victim reported within one hour, and the suspect and victim have children; and (d) perceptual shorthand was measured by measuring suspect/victim race - suspect non-white, victim non-white -

\footnotetext{
${ }^{5}$ Although O’Neal and Spohn did not include criminal history in their analysis, Hartley et al. (2007) suggested using offender criminal history as a measure of protection of the community. However, no studies were identified that examined the correlation between offender criminal history and arrest.
} 
victim consumed alcohol prior to or during incident, suspect consumed alcohol prior to or during incident, victim had motive to lie, and suspect and victim married. When determining correlates of practitioner decision-making in sexual assault cases, researchers have examined several variables that fit with focal concerns measures provided by O'Neal and Spohn (2017), but these authors were the first to explicitly place these measures in the focal concerns perspective.

I used the work of Tillyer and Hartley (2010) and O'Neal and Spohn (2017) as a guide to define and measure focal concern variables. Research found variables related to suspect blameworthiness were significantly and positively correlated with practitioner decision to arrest and charge (Alderden \& Ullman, 2012ab; Frazier \& Haney, 1996; Kerstetter, 1990; Kingsnorth et al., 1999 Morabito et al., 2019b; Spohn \& Tellis, 2019; O'Neal et al., 2019; Venema et al., 2019). Yet, others found variables related to suspect blameworthiness were insignificant correlates of arrest and charging (Kaiser et al., 2017; Scott \& Beaman, 2004; Smith, 2005; Spears \& Spohn, 1996; Spohn \& Holleran, 2001; Spohn et al., 2001). Some research found a significant and positive correlation between varaibles that measured the need for protection of the community and arrest and charging (Kerstetter, 1990; LaFree, 1981; Morabito et al., 2019b; Spohn et al., 2001; Spohn \& Tellis, 2019; Venema et al., 2019), although others report an insignificant relationship (Holleran et al., 2010; Kaiser et al., 2017; Kingsworth et al., 1999; Scott \& Beaman, 2004; Ylang \& Holtfreter, 2019). Research found a significant and positive correlation between variables related to practical constraints and arrest and charging (Beichner \& Spohn, 2005; Kaiser et al., 2017; Kingsnorth et al., 1999; LaFree, 1981, 1989; Morabito et al., 2019b; Spohn \& Holleran, 2001; Spohn et al., 2001; Spohn \& Tellis, 2019), 
however others reported an insignificant relationship between variables associated with practical constraints and arrest and charging (Alderden \& Ullman, 2012a; Holleran et al., 2010; O’Neal et al., 2019; Spears \& Spohn, 1997; Spohn \& Holleran, 2001; Tasca et al., 2013; Wentz, 2019). Lastly, research found variables related to perceptual shorthand were significantly and positively correlated to arrest and charging (Alderden \& Ullman, 2012b; Beichner \& Spohn, 2005; Morabito et al., 2019b; O’Neal et al., 2019; Spohn et al., 2001; Spohn \& Horney, 1993; Spohn \& Spears, 1996; Venema et al., 2019), but others found an insignificant relationship between variables related to perceptual shorthand and arrest and charging (Alderden \& Ullman, 2012a; Bouffard, 2000; Frazier \& Haney, 1996; Holleran et al., 2010; Kaiser et al., 2017; Scott \& Beaman, 2004; Spears \& Spohn, 1997; Spohn \& Holleran, 2010; Wentz \& Keimig, 2019). Additionally, research shows measures of victim credibility (Beichner \& Spohn, 2005; Spohn et al., 2001; Spears \& Spohn, 1996, 1997) and victim alcohol consumption (Chandler \& Torney, 1981; Kerstetter, 1990; O’Neal et al., 2019; Venema et al., 2019) were significantly and negatively correlated with reduced odds of case advancement. Still, others reported an insignificant relationship between variables related to victim credibility (Holleran et al., 2010; Kaiser et al., 2017; Morabito et al., 2019b; O'Neal et al., 2019; Spears \& Spohn, 1997; Spohn \& Tellis, 2019) and victim alcohol consumption (Scott \& Beaman, 2004; Smith, 2005; Wentz \& Keimig, 2019) with arrest and charging.

\section{The Current Study and the Need for a Systematic Meta-Analytic Review}

Some empirical evidence exists to support focal concerns as a framework to explain police and prosecutor decision-making in sexual assault cases. Indeed, a review of the literature identified several studies that found variables related to the focal 
concerns perspective were significant correlates of case advancement. Overall, however, the studies fail to reach a consensus, as many studies report insignificant results and weak correlations between focal concerns measures and police officers' decision to arrest. Because differences in findings across studies, a systematic review is needed to condense the literature and a meta-analysis is needed to assess the current state of police and prosecutor sexual assault decision-making literature. This is the first study to attempt to evaluate the magnitude and direction of the relationships between focal concerns variables and practitioner decision-making across all studies, and determine which correlates are most important to case advancement in sexual assault cases. Identifying the most important correlates of case advancement is required to inform evidenced based policy, police training and educational topics (e.g., rape myths and misconceptions, evidence processing, maintaining victim engagement, interview techniques, neurobiological trauma), help reduce case attrition during arrest and charging, and to improve criminal justice system responses to victims of sexual assault.

Based on this cursory review of the literature, studies appear to find support for the ability of focal concerns to explain arrest and prosecutorial decision-making in sexual assault cases. Each focal concern concept contained measures significantly correlated with arrest and odds of charging. However, the overall review produced mixed findings for the impact of focal concerns variables on arrest and charge decision-making and resulted in many studies reporting insignificant and weak associations between key variables to arrest and charging. As such, no study has systematically reviewed the sexual assault decision-making literature, and none have used meta-analysis to condense and evaluate correlates of case advancement through the arrest and charging stages. This 
omission is important because scholars have not calculated the effects of these focal concerns at each stage of criminal justice processing (e.g., arrest, charging), and none have combined the effects of both arrest and charging decisions to determine the strongest predictors of overall case advancement.

\section{Meta-Analysis}

First developed in the 1970s, meta-analysis is a statistical approach to synthesize literature without the innate biases associated with narrative reviews (Hunt, 1997). Because of its ability to "take stock" of literature (Cullen, 2005) and help determine what studies "really say” about a topic (Hunter \& Schmidt, 2004; Lipsey \& Wilson, 2001), meta-analysis has become widely used in criminology and criminal justice (Turanovic \& Pratt, 2020). The approach can gather large amounts of information on a topic and then synthesize results across all studies. In addition, meta-analysis uses effect sizes across studies to examine the associating a variable(s) (e.g., intervention, correlates) on outcomes. According to Johnson (2010), meta-analysis includes five steps: “(1) formulating the problem, (2) collecting the data, (3) evaluating the data, (4) synthesizing the data, (5) presenting the findings" (p. 73). Using meta-analysis allows for several advantages, such as examining the statistical relationship between variables using effect sizes, assessing the relationship strength while controlling for methodological variation, the ability to replicate meta-analysis, and ability to update meta-analysis results when new studies are available (Pratt \& Cullen, 2001).

Meta-analysis is a means to collect quantitative research on an interventions, programs, or correlates and calculate these to produce a single effect size and to better evaluate policy implications (Johnson, 2010). Meta-analysis can combine relevant studies 
to provide a single conclusion, while also containing greater statistical power because of its ability to analyze multiple studies simultaneously. Rather than count p-values across studies, meta-analysis systematically assess findings from an entire body of research and helps establish statistical significance, directionality, and strength an intervention or correlate(s) has on an outcome.

Although meta-analysis was initially developed and used within education and psychology (Cooper et al., 2019; Koricheva et al., 2013), the technique has become more common within criminal justice and criminology and helped to "take stock" of literature on many topics (Cullen, 2005; Farrington \& Welsh, 2008; Wells, 2009). In fact, a recent Google Scholar search by Turanovic and Pratt (2020) using the terms "meta-analysis" and "criminology" or "criminal justice" found over 110,000 hits, many of which were published after 2010. In criminal justice and criminology, meta-analysis has been most salient in studying the effects of correctional crime control strategies (Andrews et al., 1990; Hanson \& Bussiere, 1998; Lipsey \& Wilson, 1998), effectiveness of policing approaches (Braga et al., 2014; Braga \& Weisburd, 2012), and crime prevention strategies (Farrington \& Welsh, 2003; Welsh \& Farrington, 2009; Wilson et al., 2001). By summarizing these bodies of literature, criminal justice and criminology scholars have used meta-analysis to synthesize and assess the findings of program evaluations (Bennett et al., 2007; Piquero et al., 2016; Schmucker \& Losel, 2015), policing interventions (Braga et al., 2014; Braga \& Weisburd, 2012), and the empirical status of criminological theories (Paternoster, 1987; Pratt et al., 2006; Pratt et al., 2010; Pratt \& Cullen, 2000, 2005). 
In many academic fields it is often difficult to reach conclusions on a specific research question or hypothesis, as many studies use varying methodologies, analytic strategies, diverging findings and conclusions, and because pertinent studies are often tough to locate throughout different journals and grey matter (Denney \& Tewksbury, 2013; Mazerolle et al., 2013; Turanovic \& Pratt, 2020; Wickramasekera et al., 2015). Furthermore, issues regarding the "file drawer problem" (i.e., researchers only publishing significant findings) (Hunter \& Schmidt, 2004) and methodological differences across studies make it difficult to determine the "real findings" (see Booth et al., 2016). Additionally, only using narrative reviews causes unique problems, especially with issues concerning how reviewers determine studies to include and exclude based on their preferences (Hunt, 1997), and that many narrative reviews fail to reach substantive conclusions other than the need for future studies (Kempf, 1993, 2019). Meta-analysis, however, synthesizes empirical results across all quantitative studies and thus helps overcome many review biases and allows for objective and precise estimates, despite variations in methodologies, analytic strategies, diverging findings and conclusions. In this way, meta-analysis results can present a clearer picture on what research "really says" about a topic (Hunter \& Schmidt, 2004; Lipsey \& Wilson, 2001).

The current study follows work of previous meta-analysis studies by "taking stock" (Cullen, 2005) of the literature regarding decision-making in sexual assault cases and by assessing the empirical support of the focal concerns perspective in such cases. Because of mixed findings across studies on the topics of police officers' decision to arrest in sexual assault investigations and prosecutors' decision to charge in sexual assault cases, a meta-analysis is needed to assess the current state of the literature 
regarding case advancement in sex crime cases. The current study conducts a systematic review to synthesize the literature and to estimate the magnitude and direction for the relationships between focal concerns variables and police and prosecutor decisionmaking using meta-analysis. By doing so, the study hopes to identify the most important focal concerns for police and prosecutor decision-making, as well as determine what focal concerns are most important to overall case advancement in sexual assault cases. The goal of this meta-analysis is to help inform evidence-based policies and practices and help enhance practitioner training and educational topics (e.g., rape myths and misconceptions, evidence processing, maintaining victim engagement, sexual assault dynamics, interview techniques, neurobiology of trauma). Thus, assessing the strongest correlates of case advancement can inform evidence-based interventions aimed at improving police and prosecutor responses to sexual assault victims and potentially reduce case attrition. 


\section{CHAPTER 3}

\section{METHODOLOGY}

To my knowledge, no studies have performed a systematic meta-analytic review of the literature examining police and prosecutor decision-making in sexual assault cases. Thus, using operationalizations of focal concerns variables adapted from O’Neal and Spohn (2017), this study conducted a systematic review of the literature dating back to 1981. The study also conducted meta-analyses to evaluate the effects of each focal concern variable on police officers' decision to arrest or present a case to a prosecutor, prosecutors' decision to charge, and both arrest/present and charging decisions aggregated. This review sought to contribute to our understanding of criminal justice practitioners' decision-making in sexual assault cases by:

1. Producing a systematic meta-analytic literature review of studies assessing correlates of police and prosecutor decision-making in sexual assault cases,

2. Estimating the magnitude and direction of victim and case characteristics on arrest and charging,

3. Examining whether the effects of victim and case characteristics differ between police and prosecutor decision-making,

4. Combining police and prosecutor decision-making to determine which victim and case characteristics are most important to case advancement, and 
5. Assessing the applicability of focal concerns to understand case advancement among studies that examined both police and prosecutor decisions in sexual assault cases.

The review used guidelines published by the Campbell Collaboration of Systematic Reviews (Steering Group of the Campbell Collaboration, 2019) to code information on focal concerns variables across all relevant police and prosecutor decision-making studies. The meta-analysis used this information to calculate the average effect of each focal concern variable on decision-making outcomes across all quantitative studies. This process provided the mean effect for each focal concerns variable on police decision-making, prosecutor decision-making, and an aggregated model that combined police and prosecutor decision-making. In addition, the meta-analyses presented the overall magnitude and direction of each effect size for all focal concerns variables (Borenstein et al., 2011; Haidich, 2010; Lipsey \& Wilson, 2001; Sullivan \& Feinn, 2012). Rather than rely on mixed findings across studies of decision-making in sexual assault cases, this review "takes stock" of the mixed findings across studies and produced a single and more precise effect size to measure the magnitude of the relationship between each focal concerns variable practitioner decision-making (Cullen et al., 2006; Haidich, 2010; Turanovic \& Pratt, 2020).

\section{Sample}

The review sample included all studies that quantitatively assessed correlates of police officers decision to arrest or present a case for prosecutorial review prior to arrest and prsocutors decision to charge. These two decision-making outcomes are similar (see Spohn \& Tellis, 2019), but are substantively different than other police decisions (e.g., 
interview suspect, unfound a case, exceptionally clear a case). As such, studies analyzing clearance status (e.g., open investigation, unfounded, exceptionally cleared) and earlier measures of investigative effort (e.g., interview suspect, identify a suspect) were excluded from the review. In addition, subsamples of intimate partner assault were exluded from the analysis. Evidence suggests these cases of intimate parner assault may be handled different than other cases by the legal system and be trivialized, viewed as a "domestic squabble", a private incident between domestic partners, and less severe (Bergen, 2004; O’Neal et al., 2015). For insatance, Accordingly, the review contains studies that:

1. Included cases of reported, investigated, and prosecuted as sexual assault.

2. Included a general sample of sexual assault cases and not only a subsample (e.g., intimate partner sexual assaults) that occurred anywhere and not only the United States and was not restricted by age of the sample,

3. Quantitatively assessed police's decision to present/arrest and prosecutors' decision to charge as outcome variables,

4. Measured the effects correlates used in the focal concerns framework on police's decision to present/arrest and prosecutors' decision to charge,

5. Presented enough statistical information to compute at least one effect size from a multivariate ${ }^{6}$ model.

\footnotetext{
${ }^{6}$ Bivariate models will be included and assessed in future studies. This study included only multivariate models that take into account other independent variables and present more conseverative estimates.
} 


\section{Search Strategies}

Because I reviewed different participants (e.g., police and prosecutors) and outcomes (e.g., present/arrest, charge), the review used two separate exhaustive search strategies to locate police and prosecutor decision-making studies. In both cases, I searched the online databases (1) ProQuest Dissertation and Theses Global, (2) Criminal Justice Abstracts, (3) PsychINFO, and (4) Sociological Abstracts, because these are the most relevant databases used in criminal justice and criminology. Initially, the search was kept intentionally broad, but after searches resulted in high numbers of unrelated studies, a more focused search command was used and resulted in more pertinent studies. The search command for police decisions used $\mathrm{AB}$ (sexual assault OR rape) AND (arrest) AND (deci* OR discretion) AND (law enforcement OR police OR investigator) and occurred in January 2020 and resulted in 1,672 potential studies, while the literature search for prosecutor decision-making occurred in January of 2020, used the search command AB (sexual assault OR rape) AND (charg* OR prosecut*) AND (deci* OR discretion) AND (prosecutor OR attorney), and resulted in 1,974 studies. In addition, to further reduce the likelihood of missing relevant studies, article references were surveyed to identify additional studies. The eligibility screening was a two-step process. First, every unique article was screened by title and abstract and was only exluded if the title and abstract were clearing irrelevant or failed to meet study inclusion critieria. The final step was a full-text screening that evaluated whether the study met each specific inclusion criteria. If the study passed both step, it was included in the analysis. 


\section{Reliability of Coding}

It is critical to maintain coding fidelity to produce reliable results. Thus, a coding sheet modified from Higginson et al. (2018) was used to code the sample of articles for both police and prosecutor decision-making. The coding sheet included 25 -items and was managed using Microsoft Excel. The full 25-item coding sheet is provided in Appendix A, and was comprised of twelve methodological items (e.g., data source, sample location, sample frame), nine statistical analysis items (e.g., sample size, outcome variables, predictor variables), and the variables measuring the four focal concerns categories in each study. Once studies were screened by titles and abstracts, I completed the coding process. In order to maintain a high level of coding consistency and to calculate interrater reliability, five articles were randomly selected and coded independently by two researchers and compared for coding consistency. The Yeaton-Wortman method was used to calculate inter-rater reliability (Yeaton \& Wortman, 1993). As such, the number of agreements was divided by the total number of coding agreements. For studies on police decision-making, this resulted in agreement of $87 \%$ and is an acceptable level. Likewise, the same process was used to code the prosecutor study sample and resulted in a high $85.5 \%$ coder agreement and is an acceptable level. To resolve coding discrepancies, the two researchers met to discuss and resolve such differences (Yeaton \& Wortman, 1993). Once differences were resolved, I then coded all studies using the coding scheme produced by this process.

\section{Measures}

To assess the applicability of focal concerns to police and prosecutor decisionmaking in sexual assault cases, this review analyzed variables that measured all four focal 
concerns concepts, which includes suspect blameworthiness, community protection, practical constraints, and perceptual shorthand variables. To accomplish this, the review used Tillyer and Hartley (2010) and O'Neal and Spohn (2017) as a guide, and when needed adapted each of their focal concerns operationalizations to fit with the measures used in previous studies. O'Neal and Spohn's initial operationalizations incorporated at least one variable measuring each focal concerns concept. O'Neal and Spohn measured suspect blameworthiness using measures including whether the suspect previously sexually assaulted the victim, suspect previously physically assaulted the victim, victim was injured at the time of assault, suspect physically assaulted victim at time of incident, and victim resisted (verbally, physically, or both). The authors measured the need for community protection using measures of whether the suspect used some type of weapon. Practical constraints and consequences was measured using some variables including physical evidence collected, suspect was interviewed by police, the victim cooperated with the investigation, there was at least one witness to the incident, the victim reported within one hour, the suspect and victim have children. Lastly, they measured perceptual shorthand variables including suspect non-white, victim non-white, victim consumed alcohol prior to/during incident, suspect consumed alcohol prior to/during incident, victim had motive to lie, and suspect and victim married.

On several occasions not enough studies used the exact same variable offered by O'Neal and Spohn to warrant a meta-analysis (e.g., suspect and victim have children, suspect previously sexually assaulted the victim, suspect was interviewed by police) and in such cases I was unable to include each of these variable in the analysis. In addition, several variables proposed by O'Neal and Spohn were slightly modified to become more 
inclusive and increase total effect sizes. Specifically the review measured prompt report time within 72 hours of the assault rather than one hour, suspect and victim married was changed to intimate partner relationships, and a victim credibility measure was included as variable of perceptual shorthand. These variable modifications were made based on measurement tendencies across previous studies to ensure the review was as inclusive as possible and that effect sizes were not unnecessarily excluded from the analysis (see Turanovic \& Pratt, 2020). For example, if the review included O’Neal and Spohn's prompt report time within one hour, then slightly dissimilar variables (e.g., within seven hours or 72 hours) would be excluded and number of effect sizes reduced.

For the current review, suspect blameworthiness was operationalized using victim resistance (i.e., victim physically or verbally resisted the assault) and victim injury (i.e., physical injuries were noted on the victim). Victim resistance includes whether the victim verbally resisted or physically resisted - or both verbally and physically resisted - their attacker. Second, protection of the community included whether the suspect used, or attempted to use a weapon during the assault. Third, physical evidence, prompt report, witness(es), and victim cooperation were included as measures of practical constraints. Physical evidence included any variable measuring indicating the presence of physical evidence in the case (DNA, fingerprints, clothing). Prompt report included any case in which the victim reported the incident to an officer or medical professional within 72 hours of the assault, and victim cooperation meant that police perceived the victim was engaged with the investigation.

Finally, perceptual shorthand was measured using several extralegal variables including the victim-offender relationship (non-stranger and intimate partner 
relationships), victim and suspect age, victim and suspect race, and victim credibility. Victim credibility was measured uniquely by a large number of studies. For instance, some measured victim credibility by only using victim discrepancies, victim had motive to lie, victim engaged in risk-taking behavior, victim credibility was questioned, or victim was a prostitute. Because of this, the review created a composite measure to analyze the combined effects of victim credibility on present/arrest and charge decision-making (Pratt $\&$ Cullen, 2000). Specifically, we measured victim credibility using widely accepted definitions for credibility issues, including victim drug/alcohol use surrounding the incident, history of drug/alcohol use, history of prostitution, engagement in risk-taking behaviors, police perceptions of moral character, and inconsistent victim statements to criminal justice personnel (Campbell, 2015; O’Neal \& Spohn, 2017; Spohn et al., 2001).

\section{Moderating Variables}

Several moderator analsyses were conducted in models that examined police dicisions to arrest, prosecutor decisions to charge, and combined models assessing both arrest and charging decisions.. For example, one moderator analysis examined the effect of the study years, while another assessed the study sample size to determine if these characteristics moderated the effect size estimates. Sample year (i.e., the year the sexual assault was investigated) was analyzed to determine if the year moderated effects. It is possible changes over time may influence the association between correlates and decision-making. For instance, it is possible the way sexual assault is investigated may have changed over time. I included study sample size as a moderator to determine if larger samples moderated effects. 


\section{Risk of Bias}

A risk of bias coding sheet was adapted from work by Higginson et al. (2018), which included a string of questions presented in Appendix A. These items were modified and evaluated the study quality regarding sampling procedures, measurement of variables, sample years, sample location, and model outputs (e.g., reported model performance measures). Studies were not scored based on these items and studies were not removed based their risk of bias assessment. 
Table 3. Focal concerns definitions and measurement.

\begin{tabular}{|c|c|c|}
\hline Focal concerns & Definition & Measures \\
\hline $\begin{array}{l}\text { Suspect } \\
\text { blameworthiness }\end{array}$ & $\begin{array}{l}\text { The suspect's level of } \\
\text { culpability and seriousness } \\
\text { of the crime }\end{array}$ & $\begin{array}{l}\text { Suspect previously sexually } \\
\text { assaulted the victim } \\
\text { Suspect previously physically } \\
\text { assaulted the victim } \\
\text { Victim was injured at the time } \\
\text { of assault } \\
\text { Suspect physically assaulted } \\
\text { victim at time of incident } \\
\text { Victim resisted (verbally, } \\
\text { physically, or both) }\end{array}$ \\
\hline $\begin{array}{l}\text { Protection of the } \\
\text { community }\end{array}$ & $\begin{array}{l}\text { Protection of the } \\
\text { community from repeat } \\
\text { offenders }\end{array}$ & $\begin{array}{l}\text { Suspect used some type of } \\
\text { weapon during the assault }\end{array}$ \\
\hline $\begin{array}{l}\text { Practical constraints } \\
\text { and consequences }\end{array}$ & $\begin{array}{l}\text { Factors that increase the } \\
\text { probability of case } \\
\text { advancement }\end{array}$ & $\begin{array}{l}\text { Physical evidence collected } \\
\text { Suspect was interviewed by } \\
\text { police } \\
\text { Victim cooperated during the } \\
\text { investigation } \\
\text { At least one witness to the } \\
\text { incident } \\
\text { Victim reported within one } \\
\text { hour } \\
\text { The suspect and victim have } \\
\text { children }\end{array}$ \\
\hline $\begin{array}{l}\text { Perceptual } \\
\text { shorthand }\end{array}$ & $\begin{array}{l}\text { Extralegal factors } \\
\text { considered during } \\
\text { decision-making }\end{array}$ & $\begin{array}{l}\text { Suspect non-white } \\
\text { Victim non-white } \\
\text { Victim consumed alcohol } \\
\text { prior to/during incident } \\
\text { Suspect consumed alcohol } \\
\text { prior to/during incident } \\
\text { Victim had motive to lie } \\
\text { Suspect and victim married }\end{array}$ \\
\hline
\end{tabular}




\section{Statistical dependence across studies}

Statistical dependence is a major concern in meta-analysis and creates the risk of producing biased and inflated results (Lipsey \& Wilson, 2001). In the past, traditional meta-analysis required each effect size to be unique and independent from each other (January et al., 2011; Wilson \& Lipsey, 2006), which was often difficult because several studies shared a common data source collected in the same year(s). For instance, multiple studies used arrest data from the from Los Angeles Police Department and Los Angeles Sheriff's Department from 2008. Previously, when a variable was shared across multiple data sources, scholars advised including only one effect size estimate for a single variable to prevent potential bias (Lipsey \& Wilson, 2001). However, using this approach means limiting potential information by eliminating or reducing effect sizes (Cheung \& Chan, 2004, 2008; Tanner et al., 2016). To overcome this problem, several scholars have recommended using multilevel modeling designed to address the issue of effect size dependence in nested data and allow inclusion of all studies and effects size estimates (Hox, 2010; Raudenbush \& Bryk, 2002; Turanovic \& Pratt, 2020). Using this statistical approach protects against biases introduced by dependent measures and increases total effect size estimates.

Because the sample of effect size estimates is nested within a three-level hierarchical structure (e.g., level 1 individual effect sizes, level 2 individual studies, level 3 individual datasets), I used multilevel modeling to treat the nested level data. Multilevel modeling uses the reliability of effect size estimates from the study and dataset levels, therefore more reliable effect size estimates from level 1 (e.g., study level) and level 2 (e.g., dataset level) are given greater weight in the analysis. In this way, the approach 
prevents a study reporting 30 estimates from contributing 30 times more to an effect size estimate compared to a study reporting a single estimate (Van den Noortgate et al., 2013). This approach allowed me to include all effect size estimates and improve estimate precision. To complete this analysis, data were extracted from studies and entered an Excel spreadsheet. Data were organized by correlates that correspond to focal concerns (level 1), correlates that correspond to individual studies (level 2), and correlates that correspond to datasets (level 3). Once the data were constructed in this way, I used multilevel modeling to prevent unbalanced numbers of effect sizes per study and dataset from producing biased results (e.g., narrow confidence intervals, smaller standard errors, type one error) (Kreft and DeLeeuw, 1998). Additionally, rho, the user-specified within study effect correlation, was adjusted between 0 - 1 and unaffect the results, and thus the default value of rho was used.

\section{Effect Size Estimates}

Guided by established meta-analysis literature (see Berlin \& Colditz, 1990; Brind et al., 1996; Cosgrove et al., 2003; Fleiss 1993; Fleiss \& Berlin, 2009; Gaugler et al., 2007; Geddes \& Lawrie, 1995; Greenland, 1987; Greenland, 1993; Haddock et al., 1998; Kochel et al., 2011; Lasky-Su et al., 2005; Lipsey \& Wilson, 2001; Lösel \& Schmucker, 2005; Mitchell, 2005; Tenback et al., 2009), logged odds ratios were used as the measure of effect size estimates. Logged odds ratios were selected for several reasons. First, because studies primarily used dichotomous outcomes, logged odds ratios were the most common measure used to study police and prosecutor decision-making. However, the inclusion of a dichmoutous outcome was not an eligibility requirement. Second, most studies on police and prosecutor decision-making lacked sufficient 
bivariate data to compare effect size estimates between bivariate and multivariate models. Third, logged odds ratios helped reduce potential spuriousness observed in bivariate results and to void overestimating effect size estimates. Fourth, if logged odds ratio values are not presented, formulas are available to transform other statistics into logged odds ratio estimates (e.g., probit coefficients and variances) (Hedges \& Olkin, 1985). Fifth, logged odds ratio values are centered around zero, which makes it simple to interpret their strength and directionality (Hanushek \& Jackson, 1977). Additionally, logged odds ratios can be transformed into odds ratios (i.e., also known as the natural anti-log or exponent B). Odds ratios (OR) are easily interpreted as the odds of an outcome occurring when exposed to an independent variable, compared to the odds of an outcome occurring without the exposure of the independent variable. For instance, $\mathrm{OR}=$ 1 independent variable generated no effect, $\mathrm{OR}>1$ independent variable correlated with higher odds of outcome, and OR $<1$ correlated with lower odds of outcome (Szumilas, 2010).

\section{Analytic Strategy}

Recently, Turanovic and Pratt (2020) have argued for the field of criminal justice to reevaluate the criteria established for including and excluding studies, which "tends to result in narrowly focused meta-analyses" that fail to accurately represent existing literature (p. 3). The authors suggest traditional exclusion and inclusion criteria (e.g., $a$ priori) force multiple meta-analyses to examine the same research questions, rather than produce a single meta-analysis that includes a full body of literature. This often means that scholars fail to compare different outcomes, even when the outcomes are similar. For instance, and most relevant to this review, researchers often exclude studies because their 
outcome variables are seen as too different from each other (e.g., drug offenses vs. violent offenses). Following advice from Turanovic and Pratt (2020), this review conducted three separate meltivelevel models using random effects to be as inclusive as possible and produce results illustrative of existing evidence on the topic of case advancement in sexual assault cases. As such, model one conducted a meta-analysis that examined the correlates of police decisions to present a case for prosecutorial review and arrest, model two examines the correlates of prosecutor decisions to accept charges, and model three combined all decisions.

The first meta-analysis analyzed the effects of predictors on two police decisions, including the decision to make an arrest and the decision to present a case for prosecutorial review prior to making an arrest. Although these decisions points may appear to be different, both constitute a police decision to advance a case. For instance, Spohn and Tellis (2019) reported that police often have probable cause to make an arrest, however, some cases are rejected for prosecution when the officer presents a case for review before making an arrest. In such instances, no arrest occurs, and cases are often reported as exceptionally cleared because the prosecutor declined to accept charges. In addition, the decision to include both outcomes follows Turanovic and Pratt's (2020) recommendation to assess all studies included in a body of literature, even if the dependent variables are slightly different measures. The second meta-analysis analyzed correlates of prosecutorial decision-making. This meta-analysis examined only prosecutors and their decision to either accept or reject charges. The third meta-analysis used one model to examine police and prosecutor decision-making toegether. Doing so allows the review to assess overall correlates of case advancement from the arrest stage to 
the charging stage. Meaning, the analysis is able to determine which correlates are most important to case progression across the arrest and prosecution stages. Combining the prosecutor and policing literature in this area allows this study to take stock in the applicability of focal concerns using the body of quantitative research on sexual assault decision-making.

\section{Statistical Procedure}

Multilevel modeling was used to conduct the main meta-analyses. In multilevel modeling, level 1 contains the effect size estimates, level 2 corresponds with individual studies, and level 3 corresponds with independent datasets (see Pratt et al., 2014; Wolfe \& Lawson, 2020), which allows for every effect size across all studies to be analyzed rather than just a single effect size. The statistical procedure accounts for the possibility that effect sizes from a shared data source might be more similar than effect sizes from other studies (Raudenbush \& Bryk, 2002). Additionally, as Turanovic and Pratt noted, "a study that reports 10 effect size estimates will not contribute to the meta-analysis 10 more than a study reporting 1 effect size" but that the procedure considers the reliability of within studies (Turanovic \& Pratt, 2020, p. 12). Thus, greater weight are given to mean estimates from more reliable studies and less weight to less reliable studies. I used R's metafor package to estimate random effects models with maximum likelihood estimation to assess all variance known multilevel models. In addition, the $Q$-statistic was used to assess heterogeneity of effect sizes estimates and moderating variables.

\section{Publication Bias}

Biases are often introduced into meta-analysis results because studies with statistically insignificant findings are less likely to be published than studies with 
significant findings. To address issues of publication bias and "the file drawer problem" (Hunter \& Schmidt, 2004), five procedures were used. First, publication bias was tested by funnel plot asymmetry (Begg \& Mazumdar, 1994), and is based on the idea the plot of study effect sizes should be symmetric around the mean effect size estimate. Second, if asymmetry was detected, the trim-and-fill procedure (Duval \& Tweedie, 2000) was used to impute missing studies. Third, Egger's regression test was used to test for publication bias (Egger, 1997). Rosenthal's classic fail-safe $N$ test (Rosenthal, 1979) and Orwin's fail-safe $N$ test (Orwin, 1983). Fourth, fail-safe $N$ tests were estimated to assess the number of potentially missing studies with nonsignificant results needed to increase the mean effect size above statistical significance $\mathrm{p}<.05$ (Rosenthal, 1979). Fifth, Orwin's fail-safe $N$ test estimated the number of potential missing studies with null effects needed to reduce the mean effect for each variable to $\mathrm{OR}=1.00$. If tests produced large values, then the predictors are stable against publication bias (Hunter \& Schmidt, 1990; Lipsey \& Wilson, 2001). In addition, publication bias was assessed using results from two-level meta-analysis models, and should be interpreted with caution given the mutlilevel nature of the data. The $Q$-statistic is used to assess heterogeneity of effect sizes estimates and moderating variables.

\section{Chapter Summary}

The analytic strategy presented here was designed evaluate the strength and direction of correlates of police and prosecutor decision-making. The primary goals were to assess police officers' decision to arrest and prosecutors' decision to charge and examine the usefulness of the focal concerns perspective to explain these decisions. To attempt this goal, I used focal concerns measures offered by O'Neal and Spohn (2017) 
and assessed the magnitude and direction of each variable on poilice and prosecutor decisions to advance cases. Additionally, a separate analysis combining both arrest and charging decisions was performed to estimate which case and victim characteristics are most important to case advancement.

These analyses were completed using multilevel modeling in the main analyses, which allowed me to include the maximum number of effect sizes and improve effect size estimate precision. In addition, I conducted sub-analyses using traditional metaanalysis techniques and addressed statistical effect size dependence by using effect size selection criteria and excluding specific dependent effect sizes. By completing the subanalyses, I sought to compare traditional meta-analysis strategies suggested by Turanovic and Pratt (2020). Finally, to address issues of publication biases, funnel plots, trim-andfill procedure, Egger's regression test of publication bias were used. In addition, Rosenthal's classic fail-safe $N$ test (Rosenthal, 1979), and Orwin's fail-safe $N$ test (Orwin, 1983) were used to examine the potential impact of publication bias on p-values and mean effect sizes. 


\section{CHAPTER 4}

\section{RESULTS}

The goal of my dissertation was to explore five research questions about correlates of police and prosecutor decision-making in sexual assault cases and used three separate meta-analyses to answer these questions. The chapter presents results for arrest, charging, and both decision-making outcomes combined. The current chapter reports search results, study characteristics, meta-analysis results, forest plots, and analysis of publication bias.

\section{Police Search Results}

As shown in Figure 1, the search produced many potentially relevant studies for screening eligibility. The search located 1925 total unique studies, 35 potentially relevant studies after screening titles and abstracts, and 19 studies included in the review after full-text screening. As a result, the sample included 19 studies representing 222 effect sizes used in the meta-analysis. Several studies were eligible but excluded from the analysis because I was unable to accurately gather required statistical information. For instance, Lafree (1981) used weighted ordinary least squares, Brown et al. (2007) used Guttman-Lingoes' Smallest Space Analysis, and Snoodgrass et al. (2013) used an algorithmic model called Random Forest. In these studies I was unfortunately unable to locate an equation to accurately perform effect size transformations. In addition, Frazier and Haney (1996) and Morabito et al. (2019a) did not report standard errors or offer enough information was available to accurately calculate standard errors. 
Figure 1. Search strategy and results for police studies.

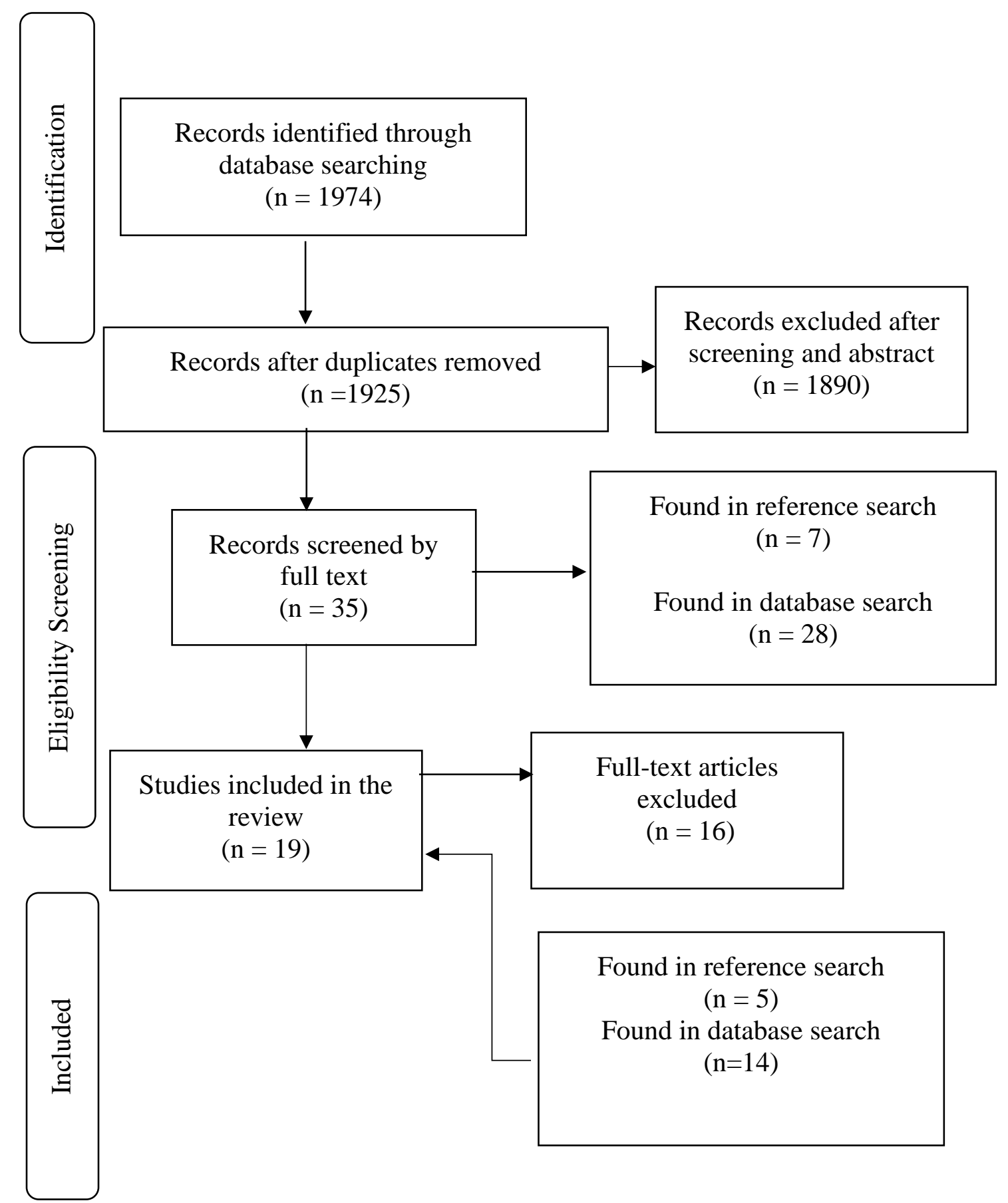




\section{Police Study Sample Characteristics}

Table 4 lists 19 studies on police decision-making, including their sample size, data collection location, sample year(s), and whether the data source was shared with, or independent of, other studies. Of these studies, twelve were published after 2010, two were published between 2000-2010, and two were published before 2000. Sixteen studies were from peer-reviewed journals, two were dissertations (Campbell, 2015; Du Mont, 1999; Smith, 2005), and one was a final report from a National Institute of Justice funded study (Morabito et al., (2019b). Two studies (Du Mont, 1999; Scott \& Beaman, 2004) occurred in Canada and the remaining took place in the United States. Two studies collected data from a rural location (Morabito et al., 2019b; Wood et al., 2011), and the remaining studies collected data from urban and/or suburban locations. Ten studies used independent data sources, and 9 analyzed shared data from the Los Angeles Police Department and Sheriff's Department (Kaiser et al., 2017; O’Neal et al., 2017; Spohn \& Tellis, 2019), a large Midwestern police department (Alderden \& Ullman, 2012a, 2012b), and a Midwestern police department (Wentz, 2019; Wentz \& Keimig, 2019). Most studies include adolescents and adult victims in their sample, although four studies restricted their analyses to adult cases (Alderden \& Ullman, 2012ab: Wentz, 2019; Wentz \& Keimig, 2019) and the age of victims included in analyses was unspecified in three studies (Bouffard, 2000; Tasca et al., 2013; Ylang \& Holtfreter). Finally, assessment of risk of bias indicated no potential risks or issues in study quality (see Appendix A). 
Table 4. Polce study characteristics

\begin{tabular}{|c|c|c|c|c|}
\hline Study & $\mathrm{N}$ & Data location & Year & Data Source \\
\hline $\begin{array}{l}\text { Alderden \& Ullman } \\
\text { (2012a) }\end{array}$ & 399 & $\begin{array}{l}\text { Large midwestern } \\
\text { police department }\end{array}$ & 2003 & Shared \\
\hline $\begin{array}{l}\text { Alderden \& Ullman } \\
\text { (2012b) }\end{array}$ & 328 & $\begin{array}{l}\text { Large midwestern } \\
\text { police department }\end{array}$ & 2003 & Shared \\
\hline Bouffard (2000) & 326 & Urban/Suburban & 1995 & Independent \\
\hline Campbell (2015) & 477 & Houston PD & 1986 & Independent \\
\hline $\begin{array}{l}\text { D'Alessio \& Stolzenber } \\
\text { (2003) }\end{array}$ & 9551 & National & 1999 & Shared \\
\hline Du Mont (1999) & 187 & Toronto, Canada & 1994 & Independent \\
\hline Horney \& Spohn (1996) & 259 & Detroit PD & 1989 & Shared \\
\hline Kaiser et al. (2017) & 770 & LAPD/LASD & 2008 & Shared \\
\hline Morabito et al. (2019b) & 2732 & $\begin{array}{c}\text { Urban, suburban, } \\
\text { \& rural }\end{array}$ & $\begin{array}{l}2008- \\
2010\end{array}$ & Independent \\
\hline O’Neal et al. (2019) & 655 & LAPD/LASD & 2008 & Shared \\
\hline Scott \& Beaman (2004) & 87 & Western Canada & 1996 & Independent \\
\hline Smith (2005) & 121 & Maryland & $\begin{array}{l}2002- \\
2003\end{array}$ & Independent \\
\hline Spohn \& Tellis (2019) & 491 & LAPD/LASD & 2008 & Shared \\
\hline Tasca et al. (2013) & 115 & Arizona City & 2003 & Independent \\
\hline Venema et al. (2019) & 22348 & $\begin{array}{c}\text { Midwestern } \\
\text { police department }\end{array}$ & $\begin{array}{l}1999- \\
20014\end{array}$ & Independent \\
\hline Wentz (2019) & 231 & $\begin{array}{c}\text { Midwestern } \\
\text { police department }\end{array}$ & $\begin{array}{l}2000- \\
2010\end{array}$ & Shared \\
\hline Wentz \& Keimig (2019) & 418 & $\begin{array}{c}\text { Midwestern } \\
\text { police department }\end{array}$ & $\begin{array}{l}2000- \\
2010\end{array}$ & Shared \\
\hline Wood et al. (2011) & 239 & Alaska & $\begin{array}{l}2003- \\
2004\end{array}$ & Independent \\
\hline Ylang \& Holtfreter (2019) & 310 & LAPD/LASD & $\begin{array}{l}1982- \\
2012\end{array}$ & Independent \\
\hline
\end{tabular}




\section{Police Meta-Analysis Results}

Table 5 below displays the average effect size estimates organized by focal concerns concepts and their effect on arrest. Table 5 also provides the number of effect sizes for each variable, logged OR estimates, OR estimates, and 95\% confidence intervals. For suspect blameworthiness, both victim resistance $(\mathrm{OR}=1.10, \mathrm{p}>.05)$ and victim injury $(\mathrm{OR}=1.15, \mathrm{p}>.05)$ had very small $^{7}$ and nonsignificant effects on arrest. Results show when a victim physically or verbally resisted their attacker, the odds of arrest were $10 \%$ higher, and when the victim was injured, the odds of arrest were $15 \%$ higher. Offender weapon use $(\mathrm{OR}=1.26, \mathrm{p}>.05)$ was the only measure of protection of the community and was statistically insignificant. Cases involving a victim believed to be cooperating with the police investigation $(\mathrm{OR}=5.90, \mathrm{p}<.001)$ had the highest odds of arrest for practical constraints and was statistically significant. When a victim was believed to be cooperating in the investigation, odds of arrest increased by $490 \%$. In addition, availability of physical evidence $(\mathrm{OR}=1.72, \mathrm{p}<.05)$ had a small effect on odds of arrest and was statistically significant. A prompt report of victimization to police (OR $=1.28, \mathrm{p}>.05)$ had a very small effect on arrest and a witness(es) to the assault $(\mathrm{OR}=$ $1.16, \mathrm{p}>.05)$ had a very small effect. Lastly, perceptual shorthand contained the most statistically significant variables. Victim substance use had a small effect $(\mathrm{OR}=.58, \mathrm{p}<$ $.05)$. When the victim reportedly used alcohol or other substances prior to the assault, the odds of arrest decreased by $42 \%$. Victim credibility $(\mathrm{OR}=.62, \mathrm{p}<.05)$ had a small and statistically significant effect on arrest, and when a report mentioned at least one variable

\footnotetext{
${ }^{7}$ Effect sizes were described as very small, small, medium, and large using recommendations by Cohen (1988).
} 
known to affect credibility, odds of arrest decreased by 38\%. Cases involving nonstrangers $(\mathrm{OR}=1.60, \mathrm{p}>.05)$ were $60 \%$ more likely to result in arrest, whereas cases involving intimate partners $(\mathrm{OR}=1.31, \mathrm{p}>.05)$ were $31 \%$ more likely to result in arrest. Suspect age $(O R=.80, p>.05)$ and victim age $(O R=.78, p>.05)$ had very small effects and were nonsignificant. While suspect race $(\mathrm{OR}=.68, \mathrm{p}>.05)$ had a small effect and was nonsignificant. Similarly, victim race $(\mathrm{OR}=.97, \mathrm{p}>.05)$ were statistically nonsignificant and had a very small effect. 
Table 5. Multivariate meta-analysis of focal concern estimates for arrest.

\begin{tabular}{|c|c|c|c|c|c|}
\hline Independent Variable & $\begin{array}{l}\text { Log. Odds } \\
\text { Ratio }\end{array}$ & $\begin{array}{l}\text { Odds } \\
\text { Ratio }\end{array}$ & $\begin{array}{c}\text { Standard } \\
\text { Error }\end{array}$ & $\begin{array}{l}\text { Ci.Lb } \\
(95 \%) \\
\end{array}$ & $\begin{array}{l}\text { Ci.Ub } \\
(95 \%) \\
\end{array}$ \\
\hline Intercept & .2626 & 1.30 & .2108 & -.1506 & .6758 \\
\hline \multicolumn{6}{|l|}{ Suspect blameworthiness } \\
\hline Resisted & .0969 & 1.10 & .2376 & -.3688 & .5627 \\
\hline Injured & .1377 & 1.15 & .2415 & -.3356 & .6111 \\
\hline \multicolumn{6}{|l|}{$\begin{array}{l}\text { Protection of the } \\
\text { community }\end{array}$} \\
\hline Weapon & .2311 & 1.26 & .2635 & -.2834 & .7496 \\
\hline \multicolumn{6}{|l|}{ Practical constraints } \\
\hline Physical evidence* & .5428 & 1.72 & .2484 & .0559 & 1.0297 \\
\hline Report time & .2470 & 1.28 & .2406 & -.2245 & .7185 \\
\hline Witness & .1476 & 1.16 & .2291 & -.3013 & .5965 \\
\hline Cooperated $* * *$ & 1.7758 & 5.90 & .2757 & 1.2355 & 2.3160 \\
\hline \multicolumn{6}{|l|}{ Perceptual shorthand } \\
\hline Non-stranger* & .4677 & 1.60 & .2326 & .0188 & .9237 \\
\hline Intimate partner & .2732 & 1.31 & .2610 & -.2383 & .7847 \\
\hline Suspect age & -.2487 & .80 & .2195 & -.6789 & .1815 \\
\hline Victim age & -.2513 & .78 & .2140 & -.6707 & .1680 \\
\hline Suspect race & -.3887 & .68 & .2484 & -.8755 & .0981 \\
\hline Victim race & -.0280 & .97 & .2312 & -.4812 & .4251 \\
\hline Credibility* & -.4742 & .62 & .2281 & -.9212 & -.0272 \\
\hline Victim substance use $*$ & -.5499 & .58 & .2666 & -1.0725 & -.0273 \\
\hline \multicolumn{6}{|l|}{ Level 1} \\
\hline ESE Variance & .0208 & & & & \\
\hline \multicolumn{6}{|l|}{ Level 2} \\
\hline Study variance & .0180 & & & & \\
\hline QE & $251.23 *$ & & & & \\
\hline QM & $203.81 * * *$ & & & & \\
\hline$N$ (ESEs) & 222 & & & & \\
\hline
\end{tabular}


Logged OR estimates for each predictor across studies were used to create a metaregression plot (see Figure 2 below). Figure 2 displays the effects for arrest decisionmaking. The plot provide a visual representation of the odds surrounding each variable, which also includes effect size estimates, standard errors, significant level, and 95\% confidence intervals. In the plot, points plotted to the right of zero indicate increased odds of arrest. These figures help visualize the overall magnitude and direction of each predictor. In addition, the precision of the estimates is shown by plotting the variables around $95 \%$ confidence intervals. Variables to the right of the solid line indicate a higher odds of arrest, while variables to the left of the solid line represent lower odds of arrest. 
Figure 2. Meta-regression and $\log$ odds ratio for arrest.

Log Odds Ratio and 95\% CI

Grouped by Statistics for each study Less likely to arrest More likely to arrest

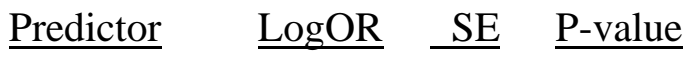

Resisted $\quad .097 \quad .238 \quad>.05$

$\begin{array}{llll}\text { Injury } & .138 \quad .242 \quad>.05\end{array}$

Weapon $\quad .231 \quad .264 \quad>.05$

$\begin{array}{llll}\text { Evidence } \quad .543 \quad & .249 \quad<.05\end{array}$

Report time $\quad .247 \quad .241 \quad>.05$

$\begin{array}{llll}\text { Witness } & .148 & .229 & >.05\end{array}$

Cooperated $\quad 1.776 \quad .276 \quad<.001$

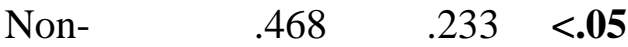

stranger

$\begin{array}{llll}\mathrm{IP} & .273 \quad .261 & >.05\end{array}$

$\begin{array}{llll}\text { Victim age } & -.251 & .214 & >.05\end{array}$

$\begin{array}{llll}\text { Suspect age } \quad-.249 & .220 & >.05\end{array}$

Victim race $\quad-.028 \quad .231>.05$

$\begin{array}{llll}\text { Suspect race } & -.389 & .248 & >.05\end{array}$

Credibility $\quad-.474 \quad .228 \quad<.05$

$\begin{array}{llll}\text { Substance } & -.550 & .267 \quad<.05\end{array}$

use

$.2626 \quad .210 \quad>.05$

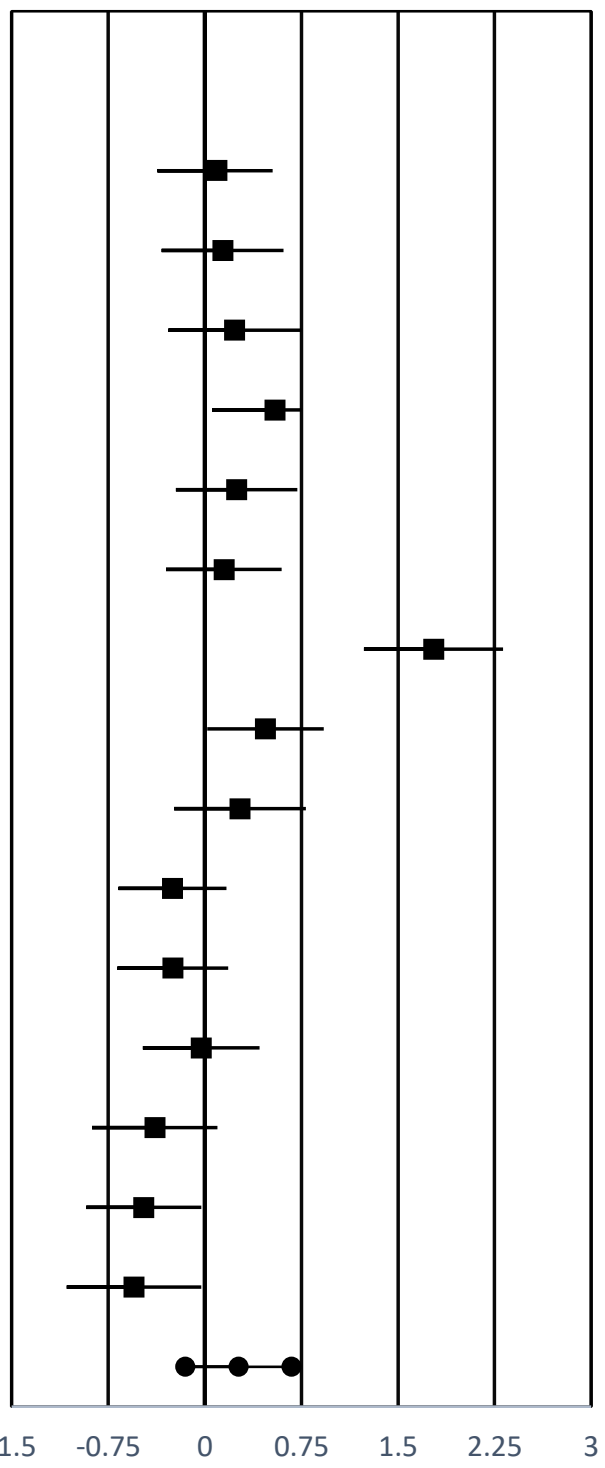

Arrest Odds 
Table 6 presents the average effect size estimate for each variable moderated by the sample year(s) of the study. Sample year was a continuous variable that was centered around its mean. This analysis sought to examine whether the sample year (i.e., the year the sexual assault was investigated) moderated effect size estimates. Results from the analysis show sample year $(p>.05)$ was nonsignificant and effect size estimate remained unchanged. 
Table 6. Multivariate meta-analysis for arrest moderated by sample year.

\begin{tabular}{|c|c|c|c|c|c|}
\hline Independent Variable & $\begin{array}{c}\text { Log. Odds } \\
\text { Ratio }\end{array}$ & $\begin{array}{l}\text { Odds } \\
\text { Ratio }\end{array}$ & $\begin{array}{c}\text { Standard } \\
\text { Error }\end{array}$ & $\begin{array}{l}\text { Ci.Lb } \\
(95 \%)\end{array}$ & $\begin{array}{l}\text { Ci.Ub } \\
(95 \%)\end{array}$ \\
\hline Intercept & .2638 & 1.30 & .2501 & -.1382 & .6658 \\
\hline \multicolumn{6}{|l|}{ Suspect blameworthiness } \\
\hline Resisted & .0900 & 1.09 & .2334 & -.3674 & -.5475 \\
\hline Injured & .1182 & 1.13 & .2356 & -.34353 & .5798 \\
\hline \multicolumn{6}{|l|}{$\begin{array}{l}\text { Protection of the } \\
\text { community }\end{array}$} \\
\hline Weapon & .2249 & 1.25 & .2568 & -.1784 & .7281 \\
\hline \multicolumn{6}{|l|}{ Practical constraints } \\
\hline Physical evidence* & .5265 & 1.69 & .2423 & .0516 & 1.0015 \\
\hline $\begin{array}{l}\text { Report time } \\
\text { Witness }\end{array}$ & .2263 & 1.25 & .2633 & -.2374 & 6899 \\
\hline Cooperated $* * *$ & 1.7971 & 6.03 & .2696 & 1.2686 & 2.3255 \\
\hline \multicolumn{6}{|l|}{ Perceptual shorthand } \\
\hline Non-stranger* & .5082 & 1.66 & .2267 & .0639 & .9526 \\
\hline Intimate partner & .1877 & 1.21 & .2554 & -.3129 & .6882 \\
\hline Suspect age & -.2431 & .78 & .2123 & -.6592 & .1730 \\
\hline Victim age & -.2350 & .79 & .2090 & -.6446 & .1746 \\
\hline Suspect race & -.2522 & .78 & .2677 & -.7768 & .2725 \\
\hline Victim race & -.0144 & .99 & .2245 & -.4515 & .4286 \\
\hline Credibility* & -.4263 & .65 & .2311 & -.8765 & -.0293 \\
\hline Victim substance use $*$ & -.5701 & .57 & .2662 & -1.0917 & -.0484 \\
\hline \multicolumn{6}{|l|}{ Moderator } \\
\hline Sample year & -.0090 & .99 & .0064 & -.0216 & .0037 \\
\hline \multicolumn{6}{|l|}{ Level 1} \\
\hline ESE Variance & .0127 & & & & \\
\hline \multicolumn{6}{|l|}{ Level 2} \\
\hline Study variance & .0750 & & & & \\
\hline QE & 162.48 & & & & \\
\hline QM & $200.67 * * *$ & & & & \\
\hline$N$ (ESEs) & 222 & & & & \\
\hline
\end{tabular}


Table 7 displays the average effect size estimates on arrest moderated by study sample size. The analysis included study sample size to determine if sample size moderated the effect size estimates. The study sample was $\operatorname{dichotomized~}^{8}(\mathrm{~N}>350=1)$ based on the sample mean across all police studies. Results from the analysis show study sample size ( $p>.05)$ was nonsignificant, meaning the effects were not moderated by study sample size. A final model including both sample year and sample size was analyzed, and results showed both study sample year $(\mathrm{p}>.05)$ and sample size $(\mathrm{p}>.05)$ did not moderate effect size estimates.

\footnotetext{
${ }^{8}$ Two outlying samples were removed when calculating the overall mean, and allowed for more equal variation between smaller and larger samples. The same method was used for the prosecutor sample and the police and prosecutor combined sample.
} 
Table 7. Multivariate meta-analysis for arrest moderated by sample size.

\begin{tabular}{|c|c|c|c|c|c|}
\hline Independent Variable & $\begin{array}{l}\text { Log. Odds } \\
\text { Ratio }\end{array}$ & $\begin{array}{l}\text { Odds } \\
\text { Ratio }\end{array}$ & $\begin{array}{l}\text { Standard } \\
\text { Error }\end{array}$ & $\begin{array}{l}\text { Ci.Lb } \\
(95 \%)\end{array}$ & $\begin{array}{l}\text { Ci.Ub } \\
(95 \%)\end{array}$ \\
\hline Intercept & .2774 & 1.32 & .2056 & -.1255 & .6803 \\
\hline \multicolumn{6}{|l|}{ Suspect blameworthiness } \\
\hline Resisted & .0898 & 1.09 & .2323 & -.3655 & .5450 \\
\hline Injured & 1329 & 1.14 & .2344 & -.3265 & .5923 \\
\hline \multicolumn{6}{|l|}{$\begin{array}{l}\text { Protection of the } \\
\text { community }\end{array}$} \\
\hline Weapon & .2476 & 1.28 & .2558 & -.2537 & .7489 \\
\hline \multicolumn{6}{|l|}{ Practical constraints } \\
\hline Physical evidence* & .5182 & 1.68 & 2410 & .0458 & 9906 \\
\hline Report time & .2392 & 1.27 & 2354 & -.2221 & .7005 \\
\hline Witness & 1001 & 1.11 & 2202 & -.3315 & .5317 \\
\hline Cooperated $* * *$ & 1.7863 & 5.98 & .2687 & 1.2597 & 2.3130 \\
\hline \multicolumn{6}{|l|}{ Perceptual shorthand } \\
\hline Non-stranger* & .5208 & 1.68 & .2252 & .0793 & .9622 \\
\hline Intimate partner & 1970 & 1.22 & 2544 & -.3015 & .6956 \\
\hline Suspect age & -.2206 & .80 & 2097 & -.6317 & 1904 \\
\hline Victim age & -.2266 & .80 & 2069 & -.6322 & 1790 \\
\hline Suspect race & -.2328 & .79 & 2661 & -.7544 & 2888 \\
\hline Victim race & .0049 & 1.00 & .2234 & -.4330 & .4428 \\
\hline Credibility* & -.4219 & .66 & .2298 & -.8723 & -.0286 \\
\hline Victim substance use* & -.5597 & .57 & .2652 & -1.0794 & -.0399 \\
\hline \multicolumn{6}{|l|}{ Moderator } \\
\hline Sample size & -.1312 & .88 & .0873 & -.3024 & .0399 \\
\hline \multicolumn{6}{|l|}{ Level 1} \\
\hline \multirow{2}{*}{\multicolumn{6}{|c|}{ Level 2}} \\
\hline & & & & & \\
\hline Study variance & .0084 & & & & \\
\hline QE & 163.80 & & & & \\
\hline QM & $203.10 * * *$ & & & & \\
\hline$N$ (ESEs) & 222 & & & & \\
\hline
\end{tabular}




\section{Police Study Sample Publication Bias}

To address the "file drawer problem" (Hunter \& Schmidt, 2004), publication bias was assessed in five ways. First, publication bias was tested by funnel plot asymmetry (Begg \& Mazumdar, 1994), and is based on the idea the plot of study effect sizes should be symmetric around the mean effect size estimate. Figure 3 shows the funnel plot for the police studies, and a visual inspection of the funnel plot indicated symmetry across effect sizes. Second, if asymmetry was detected, the trim-and-fill procedure (Duval \& Tweedie, 2000) was used to impute missing studies. That said, there was no asymmetry, and the procedure imputed no studies. Third, Egger's regression test was used to test for publication bias. Results from Egger's regression test was nonsignificant $(\mathrm{z}=1.2665, \mathrm{p}=$ .2053) and indicated no clear evidence of publication bias. Fourth, Rosenthal's classic fail-safe $N$ test estimated the potentially missing studies with nonsignificant results needed to increase the mean effect size above statistical significance $\mathrm{p}<.05$ (Rosenthal, 1979). Results were robust $(N=27,787)$ and would require many studies to increase $p$ values above $\mathrm{p}<.05$. Lastly, Orwin's fail-safe $N$ test estimated the number of potential missing studies with null effects needed to reduce the mean effect for each variable to OR $=1.00$. Likewise, results were robust $(N=6,810)$ and would require many missing studies with null effects to substantially affect effect size estimates. Results from techniques assessing publication indicate the mean effect size estimates are protected against publication bias. 
Figure 3. Funnel plot for arrest decision-making.

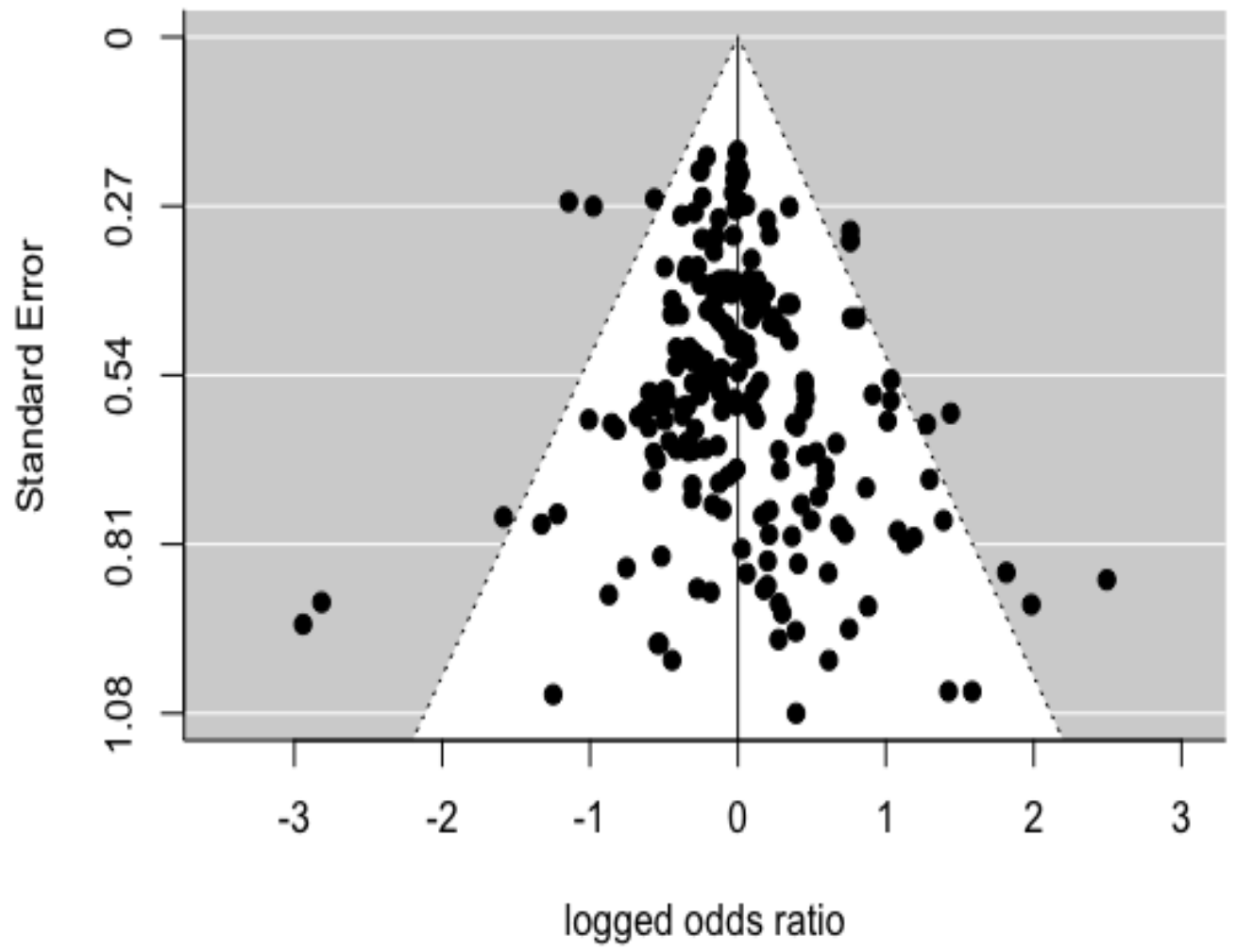




\section{Prosecutor Search Results}

Figure 4 below displays the results from the prosecutor search strategy. The search identified 1,508 total unique studies, 46 potentially relevant studies after screening titles and abstracts, and 20 studies were included in the analysis. In the end, 523 effect sizes were retained across 20 studies. Several studies were eligible but ultimately excluded from the analysis because I was unable to accurately gather required statistical information. Like the police sample, Lafree (1981) used weighted ordinary least squares, Brown et al. (2007) used Guttman-Lingoes' Smallest Space Analysis, and Kerstetter (1990) used Rao's $V$ method. In these studies I was unfortunately unable to locate an equation to accurately perform effect size transformations to logit coefficients. 
Figure 4. Search strategy and results for prosecutor studies.

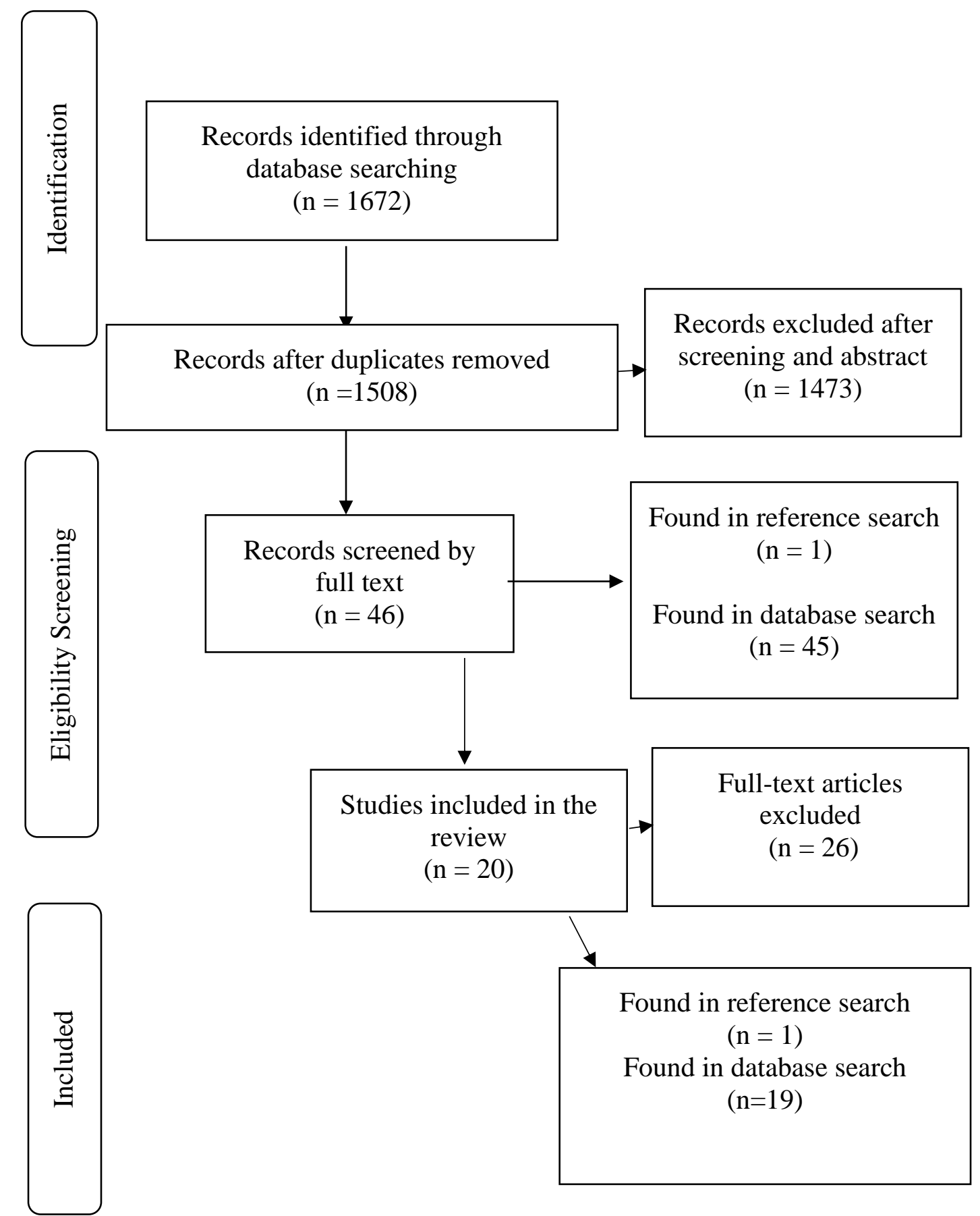




\section{Prosecutor Study Sample Characteristics}

Table 8 below lists all 20 studies that examined prosecutor decision-making. Of these, ten were published after 2010, five were published between 2000-2010, and five were published before 2000. Eighteen studies were published in peer-reviewed journals, one was a final report from a National Institute of Justice funded study (Morabito et al., (2019b), and one study was a dissertation (Du Mont, 1999). As shown in Table 8, studies were primarily scattered across the United States and two studies collected data from Canada (Du Mont, 1999; Scott \& Beaman, 2004). Two studies reported collecting data from a rural location (Morabito et al., 2019b; Wood et al., 2011), with the remaining largely collected from urban or suburban locations. Six studies used independent data sources and fourteen studies analyzed data collected from a combination of Miami, FL, Philadelphia, PA, and Kansas City, Mo (Beichner \& Spohn, 2005; Beichner \& Spohn, 2012; Holleran et al., 2010; Spohn and Holleran, 2001), Detroit police department (Horney \& Spohn, 1996; Spears \& Spohn, 1996; Spears \& Spohn, 1997), Los Angeles police department and Sheriff's Department (O’Neal et al., 2017; Spohn \& Tellis, 2019; St. George \& Spohn, 2018), and a large Midwestern police department (Wentz, 2014; Wentz, 2019). Most studies included adolescent and adult victims in their sample, however, two included all ages (Spears \& Spohn, 1996; Spears \& Spohn, 1997) and one included only adults (Alderden \& Ullman, 2012a). Finally, assessment of risk of bias indicated no potential risks or issues in study quality (see Appendix A). 
Table 8. Prosecutor study characteristics.

\begin{tabular}{|c|c|c|c|c|}
\hline Study & $\mathrm{N}$ & Data location & Year & Data Source \\
\hline Alderden \& Ullman (2012a) & 399 & $\begin{array}{l}\text { Large midwestern } \\
\text { police department }\end{array}$ & 2003 & Shared \\
\hline Beichner \& Spohn (2005) & 380 & $\begin{array}{c}\text { Kansas City, MO/ } \\
\text { Miami, FL }\end{array}$ & 1996-1998 & Shared \\
\hline Beichner \& Spohn (2012) & 630 & $\begin{array}{c}\text { Miami, FL/Kansas } \\
\text { City, MO/ } \\
\text { Philadelphia, PA }\end{array}$ & 1996-1998 & Shared \\
\hline Du Mont (1999) & 187 & Toronto, Canada & 1994 & Independent \\
\hline Holleran et al. (2010) & 386 & $\begin{array}{l}\text { Kansas City, MO/ } \\
\text { Philadelphia, PA }\end{array}$ & 1996-1998 & Shared \\
\hline Horney \& Spohn (1996) & 662 & Detroit PD & 1989 & Shared \\
\hline Kingsnorth et al. (1999) & 432 & Sacramento, CA & 1992-1994 & Independent \\
\hline Morabito et al. (2019b) & 2732 & $\begin{array}{l}\text { Urban, suburban, } \\
\text { \& rural }\end{array}$ & $2008-2010$ & Independent \\
\hline O’Neal et al. (2019) & 655 & LAPD/LASD & 2008 & Shared \\
\hline Scott \& Beaman (2004) & 87 & Western Canada & 1996 & Independent \\
\hline Spears \& Spohn (1996) & 318 & Detroit PD & 1989 & Shared \\
\hline Spears \& Spohn (1997) & 321 & Detroit PD & 1989 & Shared \\
\hline Spohn et al. (2001) & 127 & Miami, FL & 1997 & Shared \\
\hline Spohn \& Holleran (2001) & 500 & $\begin{array}{l}\text { Kansas City, MO/ } \\
\text { Philadelphia, PA }\end{array}$ & 1996-1998 & Shared \\
\hline Spohn \& Tellis (2019) & 491 & LAPD/LASD & 2008 & Shared \\
\hline St. George \& Spohn (2018) & 476 & LAPD/LASD & 2008 & Shared \\
\hline Tellis \& Spohn (2008) & 689 & San Diego, CA & 1995-2002 & Independent \\
\hline Wentz (2014) & 231 & $\begin{array}{l}\text { Midwestern police } \\
\text { department }\end{array}$ & $2000-2010$ & Shared \\
\hline Wentz (2019) & 231 & $\begin{array}{l}\text { Midwestern police } \\
\text { department }\end{array}$ & $2000-2010$ & Shared \\
\hline Wood et al. (2011) & 239 & Alaska & 2003-2004 & Independent \\
\hline
\end{tabular}




\section{Prosecutor Meta-Analysis Results}

Table 9 below displays the average effect size estimates organized by focal concerns concepts and their effect on charging. For suspect blameworthiness, both victim resistance $(\mathrm{OR}=.89, \mathrm{p}>.05)$ and victim injury $(\mathrm{OR}=1.40, \mathrm{p}>.05)$ were nonsignificant and had very small effects. For protection of the community, when the suspect used a weapon $(\mathrm{OR}=1.23, \mathrm{p}>.05)$, odds of charging increased by $23 \%$. Practical constraints variables had the strongest effect on charging. Availability of physical evidence $(\mathrm{OR}=$ $1.75, \mathrm{p}>.05)$ and prompt report $(\mathrm{OR}=1.47, \mathrm{p}>.05)$ were nonsignificant and had small

effects on charging. Both victim cooperation $(\mathrm{OR}=.5 .74, \mathrm{p}<.001)$ had a large effect and the availability of a witness to the assault $(\mathrm{OR}=2.19, \mathrm{p}>.05)$ had a small effect and each were significant. When the victim was believed to be cooperating with practitioners, odds of charging increased by $474 \%$, and when a witness was present, odds of charging increased by $119 \%$. For perceptual shorthand variables, non-stranger relationships, (OR $=.69, \mathrm{p}>.05)$, intimate partner relationships $(\mathrm{OR}=.61, \mathrm{p}>.05)$, suspect age $(\mathrm{OR}=.86$ $\mathrm{p}>.05)$, victim age $(\mathrm{OR}=.83, \mathrm{p}>.05)$, suspect race $(\mathrm{OR}=.71, \mathrm{p}>.05)$, and victim race $(\mathrm{OR}=.99, \mathrm{p}>.05)$ had very small effects on odds of charging and were nonsignificant. Non-stranger cases were $31 \%$ fewer odds of charging, intimate partner cases had $39 \%$ fewer odds of charging, and when the suspect was non-white, odds of chargeing decreased by $29 \%$. Victim credibility $(O R=.52, \mathrm{p}<.05)$ had a small and significant effect on charging, and odds of arrest decreased by $48 \%$ when a report mentioned one variable that is known to affect credibility. Finally, if the victim used alcohol or drugs prior to the assault $(\mathrm{OR}=.52, \mathrm{p}>.05)$, odds of charging decreased by $48 \%$. 
Table 9. Multivariate meta-analysis of focal concern estimates for charging.

\begin{tabular}{|c|c|c|c|c|c|}
\hline Independent Variable & $\begin{array}{l}\text { Log. Odds } \\
\text { Ratio }\end{array}$ & $\begin{array}{l}\text { Odds } \\
\text { Ratio }\end{array}$ & $\begin{array}{l}\text { Standard } \\
\text { Error }\end{array}$ & $\begin{array}{l}\text { Ci.Lb } \\
(95 \%)\end{array}$ & $\begin{array}{l}\text { Ci.Ub } \\
(95 \%)\end{array}$ \\
\hline Intercept & .2844 & 1.33 & .3121 & -.3293 & .8981 \\
\hline \multicolumn{6}{|l|}{ Suspect blameworthiness } \\
\hline Resisted & -.1116 & .89 & .3317 & -.7617 & .5384 \\
\hline Injured & .3321 & 1.40 & .3310 & -.3165 & .9808 \\
\hline \multicolumn{6}{|l|}{$\begin{array}{l}\text { Protection of the } \\
\text { community }\end{array}$} \\
\hline Weapon & .2015 & 1.23 & .3396 & -.4641 & .8672 \\
\hline \multicolumn{6}{|l|}{ Practical constraints } \\
\hline Physical evidence & .5610 & 1.75 & .3313 & -.0883 & 1.2103 \\
\hline Report time & .3878 & 1.47 & .3337 & -.2661 & 1.0418 \\
\hline Witness* & .7851 & 2.19 & .3316 & .1352 & 1.4350 \\
\hline Cooperated $* * *$ & 1.7483 & 5.74 & .3989 & .9665 & 2.5301 \\
\hline \multicolumn{6}{|l|}{ Perceptual shorthand } \\
\hline Non-stranger & -.3725 & .69 & .3383 & -1.0355 & .2906 \\
\hline Intimate partner & -.4945 & .61 & .3625 & -1.2049 & .2160 \\
\hline Suspect age & -.1477 & .86 & .3306 & -.7956 & .5003 \\
\hline Victim age & -.1880 & .83 & .3166 & -.8085 & .4324 \\
\hline Suspect race & -.3496 & .71 & .3258 & -.9883 & .2890 \\
\hline Victim race & -.0134 & .99 & .3156 & -.6320 & .6051 \\
\hline Credibility* & -.6603 & .52 & .3067 & $1.2615-$ & -.0591 \\
\hline Victim substance use & -.6620 & .52 & .3593 & -1.3661 & .0421 \\
\hline \multicolumn{6}{|l|}{ Level 1} \\
\hline ESE Variance & .2956 & & & & \\
\hline \multicolumn{6}{|l|}{ Level 2} \\
\hline Study variance & .0990 & & & & \\
\hline QE & $1038.09 * * *$ & & & & \\
\hline $\mathrm{QM}$ & $170.63 * * *$ & & & & \\
\hline$N$ (ESEs) & 523 & & & & \\
\hline
\end{tabular}


Logged OR estimates for each predictor across studies were used to create a metaregression plot (see Figure 5 below). Figure 5 displays the plot for charge decisionmaking. The plot provides a visual representation of the odds surrounding each variable, which also includes effect size estimates, standard errors, significant level, and 95\% confidence intervals. In the plot, points plotted to the right of zero indicate increased odds of charging. This figure help visualize the overall magnitude and direction of each predictor. In addition, the precision of the estimates is shown by plotting the variables around 95\% confidence intervals. Variables to the right of the solid line indicate a higher odds of charging, while variables to the left of the solid line represent lower odds of charging. 
Figure 5. Meta-regression plot and log odds ratio for charging.

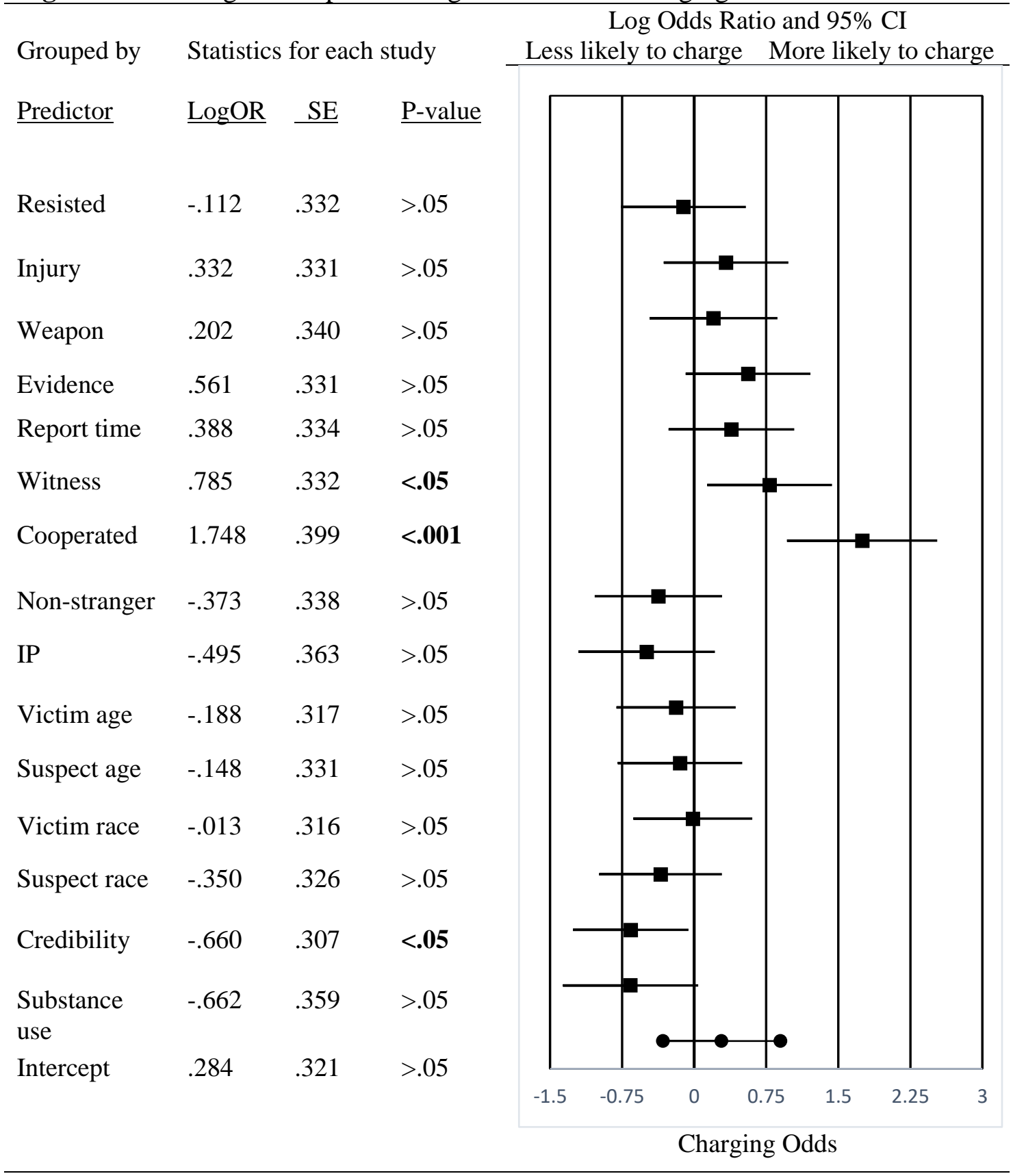


Table 10 presents the average effect size estimate for each variable moderated by the sample year(s) of the study. Sample year was also used as a continuous variable that was centered around its mean. This analysis sought to examine whether the sample year (i.e., the year the sexual assault was investigated) moderated the effect sizes. Results from the analysis show sample year $(\mathrm{p}>.05)$ and effect size estimate remained unchanged. 
Table 10. Multivariate meta-analysis for charging moderated by sample year.

\begin{tabular}{|c|c|c|c|c|c|}
\hline Independent Variable & $\begin{array}{l}\text { Log. Odds } \\
\text { Ratio }\end{array}$ & $\begin{array}{l}\text { Odds } \\
\text { Ratio }\end{array}$ & $\begin{array}{l}\text { Standard } \\
\text { Error }\end{array}$ & $\begin{array}{l}\text { Ci.Lb } \\
(95 \%)\end{array}$ & $\begin{array}{l}\text { Ci.Ub } \\
(95 \%)\end{array}$ \\
\hline Intercept & .2505 & 1.28 & .3181 & -.3730 & .8740 \\
\hline \multicolumn{6}{|l|}{ Suspect } \\
\hline \multicolumn{6}{|l|}{ blameworthiness } \\
\hline Resisted & -.1419 & .87 & .3325 & -.7936 & .5099 \\
\hline Injured & .3781 & 1.46 & .3324 & -.2734 & 1.0296 \\
\hline \multicolumn{6}{|l|}{$\begin{array}{l}\text { Protection of the } \\
\text { community }\end{array}$} \\
\hline Weapon & .2155 & 1.24 & .3395 & -.4499 & .8810 \\
\hline \multicolumn{6}{|l|}{ Practical constraints } \\
\hline Physical evidence & .5299 & 1.70 & .3329 & -.1225 & 1.1823 \\
\hline Report time & .4231 & 1.53 & .3360 & -.2354 & 1.0816 \\
\hline Witness* & .7870 & 2.20 & .3311 & .1380 & 1.4360 \\
\hline Cooperated $* * *$ & 1.7795 & 5.93 & .4003 & .9949 & 2.5640 \\
\hline \multicolumn{6}{|l|}{ Perceptual shorthand } \\
\hline Non-stranger & -.3549 & .70 & .3384 & -1.0180 & .3083 \\
\hline Intimate partner & -.4745 & .62 & .3624 & -1.1848 & .2358 \\
\hline Suspect age & -.1226 & .89 & .3316 & -.7726 & .5274 \\
\hline Victim age & .1835 & .83 & .3209 & -.8124 & .4454 \\
\hline Suspect race & -.2793 & .76 & .3292 & -.9245 & .3660 \\
\hline Victim race & .0256 & 1.03 & .3171 & -.5959 & .6471 \\
\hline Credibility* & -.6148 & .54 & .3081 & -1.2187 & -.0108 \\
\hline Victim substance use & -.6323 & .53 & .3601 & -1.3380 & .0734 \\
\hline \multicolumn{6}{|l|}{ Moderator } \\
\hline Sample year & -.0076 & .99 & .0110 & -.0291 & .0139 \\
\hline \multicolumn{6}{|l|}{ Level 1} \\
\hline ESE Variance & .2921 & & & & \\
\hline \multicolumn{6}{|l|}{ Level 2} \\
\hline Study variance & .1068 & & & & \\
\hline QE & $996.45 * * *$ & & & & \\
\hline QM & $165.72 * * *$ & & & & \\
\hline$N(\mathrm{ESEs})$ & 523 & & & & \\
\hline
\end{tabular}


Table 11 presents the average effect size estimates on charging moderated by study sample size. The study sample was dichotomized $(\mathrm{N}>300=1)$ based on the sample mean across all prosecutor studies, which is why the variable is dichtomomized differently than the police sample, and aimed to examine whether study sample had a moderating effect. Results showed study sample size ( $p$ > .05) was nonsignificant and results remained unchanged. Finally, the final model including both sample year and sample size was analyzed. Results showed both study sample year ( $>$ > .05) and sample size $(p>.05)$ had no moderating effect. 
Table 11. Multivariate meta-analysis for charging moderated by sample size.

\begin{tabular}{|c|c|c|c|c|c|}
\hline $\begin{array}{l}\text { Independent } \\
\text { Variable }\end{array}$ & $\begin{array}{c}\text { Log. Odds } \\
\text { Ratio }\end{array}$ & $\begin{array}{l}\text { Odds } \\
\text { Ratio }\end{array}$ & $\begin{array}{c}\text { Standard } \\
\text { Error }\end{array}$ & $\begin{array}{l}\text { Ci.Lb } \\
(95 \%) \\
\end{array}$ & $\begin{array}{l}\text { Ci.Ub } \\
(95 \%) \\
\end{array}$ \\
\hline Intercept & .2866 & 1.33 & .3193 & -.3392 & .9124 \\
\hline \multicolumn{6}{|l|}{$\begin{array}{l}\text { Suspect } \\
\text { blameworthiness }\end{array}$} \\
\hline Resisted & -.1520 & .86 & .3325 & -.8037 & .4997 \\
\hline Injured & .3636 & 1.44 & .3319 & -.2869 & 1.0140 \\
\hline \multicolumn{6}{|l|}{$\begin{array}{l}\text { Protection of the } \\
\text { community }\end{array}$} \\
\hline Weapon & .2012 & 1.22 & .3393 & -.4637 & .8661 \\
\hline \multicolumn{6}{|l|}{$\begin{array}{l}\text { Practical } \\
\text { constraints }\end{array}$} \\
\hline $\begin{array}{l}\text { Physical } \\
\text { evidence }\end{array}$ & .5078 & 1.66 & .3314 & -.1417 & 1.1573 \\
\hline Report time & .4081 & 1.50 & .3354 & -.2493 & 1.0655 \\
\hline Witness* & .7762 & 2.17 & .3310 & .1275 & 1.4249 \\
\hline Cooperated $* * *$ & 1.7509 & 5.76 & .3988 & .9692 & 2.5326 \\
\hline \multicolumn{6}{|l|}{$\begin{array}{l}\text { Perceptual } \\
\text { shorthand }\end{array}$} \\
\hline Non-stranger & -.3722 & .69 & .3376 & -1.0339 & .2895 \\
\hline Intimate partner & -.4884 & .61 & .3625 & -1.1990 & .2221 \\
\hline Suspect age & -.1479 & .86 & .3298 & -.7942 & .4985 \\
\hline Victim age & -.2043 & .82 & .3200 & -.8316 & .4229 \\
\hline Suspect race & -.3103 & .73 & .3260 & -.9493 & .3287 \\
\hline Victim race & .0008 & 1.00 & .3150 & -.6165 & .6181 \\
\hline Credibility* & -.6397 & .53 & .3062 & -1.2398 & -.0396 \\
\hline Victim & -.6574 & .52 & .3604 & -1.3637 & .0489 \\
\hline \multicolumn{6}{|l|}{ substance use } \\
\hline \multicolumn{6}{|l|}{ Moderator } \\
\hline Sample size & .0210 & 1.02 & .0893 & -.1690 & .1809 \\
\hline \multicolumn{6}{|l|}{ Level 1} \\
\hline ESE Variance & .2918 & & & & \\
\hline \multicolumn{6}{|l|}{ Level 2} \\
\hline Study variance & .1154 & & & & \\
\hline QE & $1008.30 * * *$ & & & & \\
\hline QM & 165.07 & & & & \\
\hline$N($ ESEs $)$ & 523 & & & & \\
\hline
\end{tabular}

*Statistically significant at $\mathrm{p}<.05, * *$ statistically significant at $\mathrm{p}<.01, * * *$ statistically significant at $\mathrm{p}<.001 . N$ denotes the total number of effect size estimates. QE displays the test results for effect size heterogeneity, while QM displays the test results for moderator heterogeneity. 


\section{Prosecutor Study Sample Publication Bias}

The same five methods used to assess publication bias in the police sampler were used to assess publication bias within the prosecutor sample. First, publication bias was tested by funnel plot asymmetry (Begg \& Mazumdar, 1994), and visual inspection of Figure 6 showed symmetry. Next, the trim-and-fill procedure was used and imputed effect sizes to the right of the mean, as shown in Figure 7. The adjusted model estimate after applying the trim-and-fill procedure was .3912. Imputed studies were likely the result of most credibility effect sizes being negatively correlated with arrest rather than publication bias. Third, Egger's regression test $(\mathrm{z}=-.2028, \mathrm{p}=.8393)$ was nonsignificant and indicates no clear evidence of publication bias (Egger, 1997). Fourth, Rosenthal's classic fail-safe $N$ test $(N=6,471)$ were robust and would require many studies for the mean effect size to become nonsignificant. Similarly, Orwin's fail-safe $N$ test $(N=5,177)$ were robust and would require a sizeable number of missing effect sizes to nullify the mean effect. Tests for publication bias indicate the sample is procted against potential bias. 
Figure 6. Funnel plot for charge decision-making.

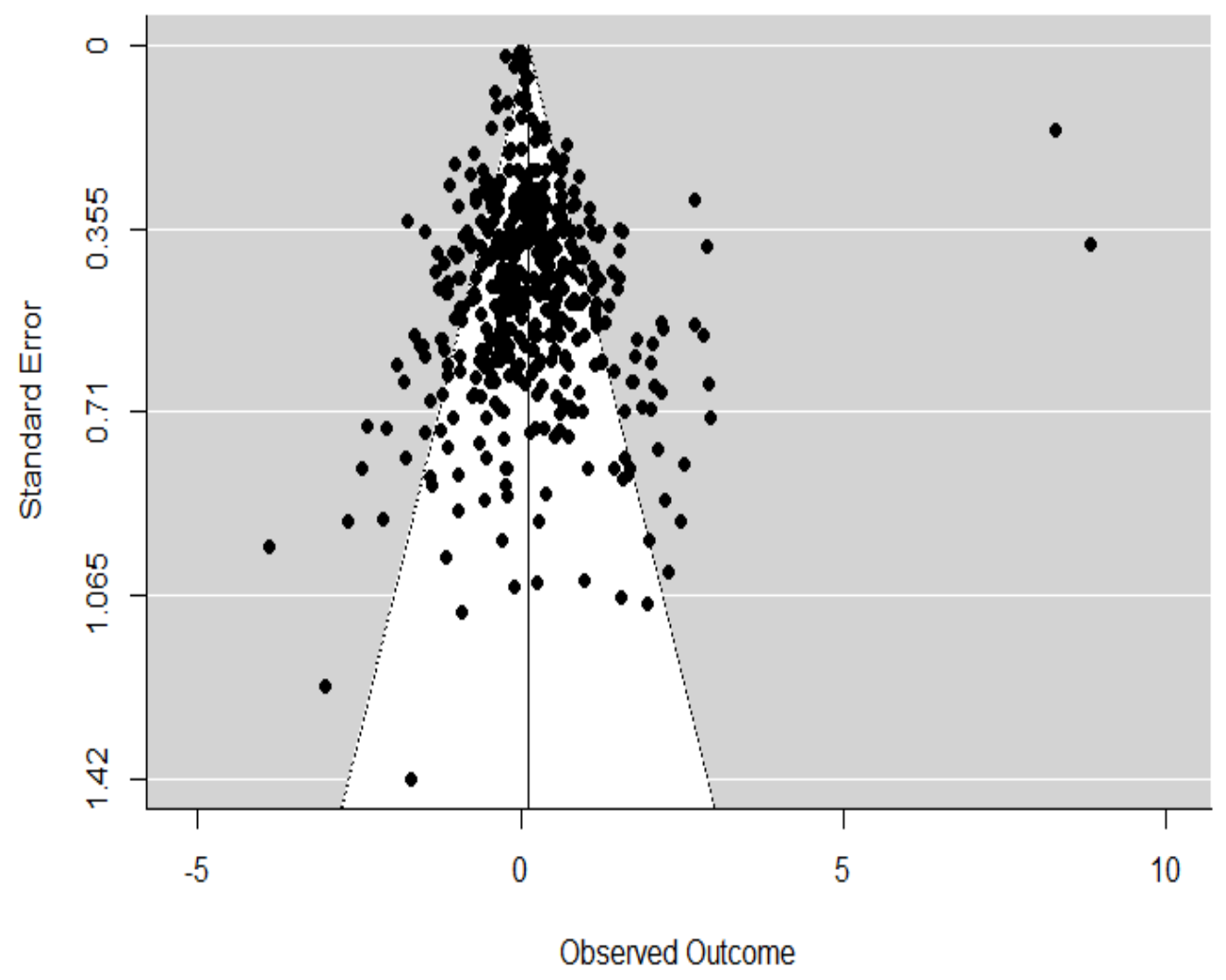


Figure 7. Trim-and-fill procedure for charge decision-making.

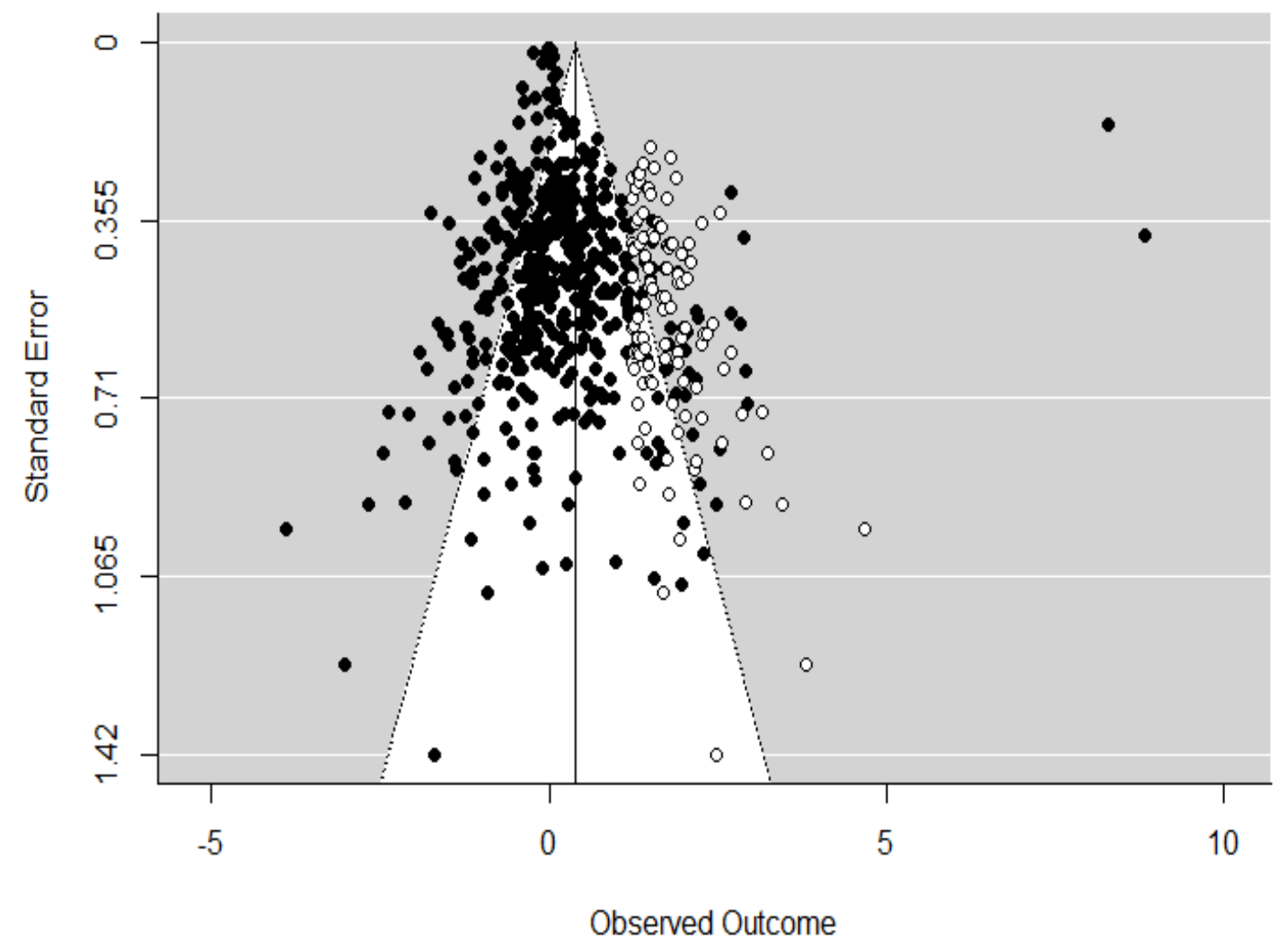




\section{Police and Prosecutor Meta-Analysis Results}

Table 12 below displays the average effect size estimates organized by focal concerns concepts and their effect on case advancement - arrest and charging. For suspect blameworthiness, both victim resistance $(\mathrm{OR}=97, \mathrm{p}>.05)$ and victim injury $(\mathrm{OR}=1.29, \mathrm{p}>.05)$ were statistically insignificant and had very small effects on case advancement. When the victim was injured, the odds of case advancement were $29 \%$ higher. Offender weapon use $(\mathrm{OR}=1.22, \mathrm{p}>.05)$ was the only variable analyzed for protection of the community and had a very small and nonsignificant effect. Cases involving a victim believed to be cooperating with practitioners $(\mathrm{OR}=5.81, \mathrm{p}<.001)$ had the highest odds of advancement for practical constraints and was statistically significant. When a victim was believed to be cooperating in the investigation, odds of advancement increased by $481 \%$. In addition, the availability of physical evidence $(\mathrm{OR}=$ $1.81, \mathrm{p}<.05)$ had a small effect on case advancement and was statistically significant. When physical evidence was available, odds of case advancement increased by $81 \%$. A prompt report of victimization to police $(\mathrm{OR}=1.40, \mathrm{p}>.05)$ was nonsignificant and increased odds of advancement by $40 \%$. A witness(es) to the assault $(\mathrm{OR}=1.81, \mathrm{p}<.01)$ was statistically significant and had a small effect on advancement. For perceptual shorthand, victim credibility $(\mathrm{OR}=.55, \mathrm{p}<.01)$ and victim substance use $(\mathrm{OR}=.53, \mathrm{p}<$ .01 ) had the greatest effects on case advancement, and when a report mentioned at least one variable known to affect credibility, odds of case advancement decreased by $45 \%$, and when the victim reportedly used alcohol or other substances prior to the assault, the odds of case advancement decreased by $47 \%$. Both relationship types, non-stranger (OR $=1.02, \mathrm{p}>.05)$ and intimate partner $(\mathrm{OR}=.94, \mathrm{p}>.05)$ were nonsignificant and had 
very small effects. Suspect age $(\mathrm{OR}=.80, \mathrm{p}>.05)$, victim age $(\mathrm{OR}=.81, \mathrm{p}>.05)$, suspect race $(O R=.70, p>.05)$ were statistically nonsignificant and had very small effects on case advancement. Victim race $(\mathrm{OR}=.97, \mathrm{p}>.05)$ was statistically nonsignificant and had a very small effect on case advancement. 
Table 12. Multivariate meta-analysis of focal concern estimates for case advancement.

\begin{tabular}{|c|c|c|c|c|c|}
\hline Independent Variable & $\begin{array}{l}\text { Log. Odds } \\
\text { Ratio }\end{array}$ & $\begin{array}{l}\text { Odds } \\
\text { Ratio }\end{array}$ & $\begin{array}{l}\text { Standard } \\
\text { Error }\end{array}$ & $\begin{array}{l}\text { Ci.Lb } \\
(95 \%)\end{array}$ & $\begin{array}{l}\text { Ci.Ub } \\
(95 \%)\end{array}$ \\
\hline Intercept & .2655 & 1.30 & 2011 & -.1276 & .6606 \\
\hline \multicolumn{6}{|l|}{ Suspect blameworthiness } \\
\hline Resisted & -.0357 & 97 & .2191 & -.4650 & 3937 \\
\hline Injured & .2551 & 1.29 & .2227 & -.1814 & 6916 \\
\hline \multicolumn{6}{|l|}{$\begin{array}{l}\text { Protection of the } \\
\text { community }\end{array}$} \\
\hline Weapon & .2018 & 1.22 & .2317 & -.2524 & 6560 \\
\hline \multicolumn{6}{|l|}{ Practical constraints } \\
\hline Physical evidence** & .5951 & 1.81 & .2235 & .1570 & 1.0333 \\
\hline Report time & .3329 & 1.40 & .2231 & -.1044 & .7702 \\
\hline Witness** & .5957 & 1.81 & .2222 & .1602 & 1.0312 \\
\hline Cooperated $* * *$ & 1.7588 & 5.81 & .2581 & 1.2530 & 2.2646 \\
\hline \multicolumn{6}{|l|}{ Perceptual shorthand } \\
\hline Non-stranger & .0225 & 1.02 & .2218 & -.4121 & 4572 \\
\hline Intimate partner & -.0647 & .94 & 2418 & -.5386 & 4092 \\
\hline Suspect age & -.2280 & .80 & 2171 & -.6535 & 1975 \\
\hline Victim age & -.2080 & .81 & .2088 & -.6172 & 2013 \\
\hline Suspect race & -.3620 & .70 & 2187 & -.7907 & .0666 \\
\hline Victim race & -.0132 & .97 & .2099 & -.4245 & .3981 \\
\hline Credibility** & -.5974 & .55 & .2049 & -.9990 & -.1959 \\
\hline Victim substance use ${ }^{* *}$ & -.6447 & .53 & 2393 & -1.1138 & -.1756 \\
\hline \multicolumn{6}{|l|}{ Level 1} \\
\hline ESE Variance & .1852 & & & & \\
\hline \multicolumn{6}{|l|}{ Level 2} \\
\hline Study variance & .0549 & & & & \\
\hline $\mathrm{QE}$ & $1355.80^{* * *} *$ & & & & \\
\hline QM & $289.25 * * *$ & & & & \\
\hline$N$ (ESEs) & 746 & & & & \\
\hline
\end{tabular}


Logged OR estimates for each predictor across studies were used to create a metaregression plot (see Figure 8 below). Figure 8 shows the plot for odds of case advancement. The plots provides a visual representation of the odds surrounding each variable, which also include effect size estimates, standard errors, significant level, and 95\% confidence intervals. In the plot, points plotted to the right of zero indicate increased odds of case advancement. This figures help visualize the overall magnitude and direction of each predictor. In addition, the precision of the estimates is shown by plotting the variables around 95\% confidence intervals. Variables to the right of the solid line indicate a higher odds of case advancement, while variables to the left of the solid line represent lower odds of case advancement. 
Figure 8. Meta-regression plot and log odds ratio case advancement.

Log Odds Ratio and 95\% CI

Less likely to advance More likely to

Grouped by Statistics for each study

$\underline{\text { Predictor }} \quad \underline{\operatorname{LogO}} \quad \underline{\mathrm{SE}} \quad \underline{\text { P-value }}$

$\begin{array}{llll}\text { Resisted } & -.036 & .219 & >.05\end{array}$

$\begin{array}{llll}\text { Injury } & .255 \quad .223 \quad>.05\end{array}$

Weapon $\quad .202 \quad .232 \quad>.05$

$\begin{array}{llll}\text { Evidence } & .595 & .224 & <.01\end{array}$

Report time $\quad \begin{array}{lll}333 & .223 & >.05\end{array}$

$\begin{array}{llll}\text { Witness } & .596 & .222 \quad<.01\end{array}$

$\begin{array}{llll}\text { Cooperated } & 1.759 & .258 \quad<.001\end{array}$

$\begin{array}{llll}\text { Non- } & -.023 & .222 & >.05\end{array}$

stranger

$\begin{array}{llll}\text { Victim age } & -.208 \quad .209 & >.05\end{array}$

$\begin{array}{llll}\text { Suspect age } & -.228 & .217 & >.05\end{array}$

Victim race $\quad-.013 \quad .210 \quad>.05$

$\begin{array}{llll}\text { Suspect race } & -.362 & .219 & >.05\end{array}$

$\begin{array}{llll}\text { Credibility } \quad-.597 \quad & .205 \quad \mathbf{0 1}\end{array}$

$\begin{array}{llll}\text { Substance } & -.645 & .639 & \mathbf{< . 0 1}\end{array}$

use

$\begin{array}{llll}\text { Intercept } & -.266 & .201 & >.05\end{array}$ advance

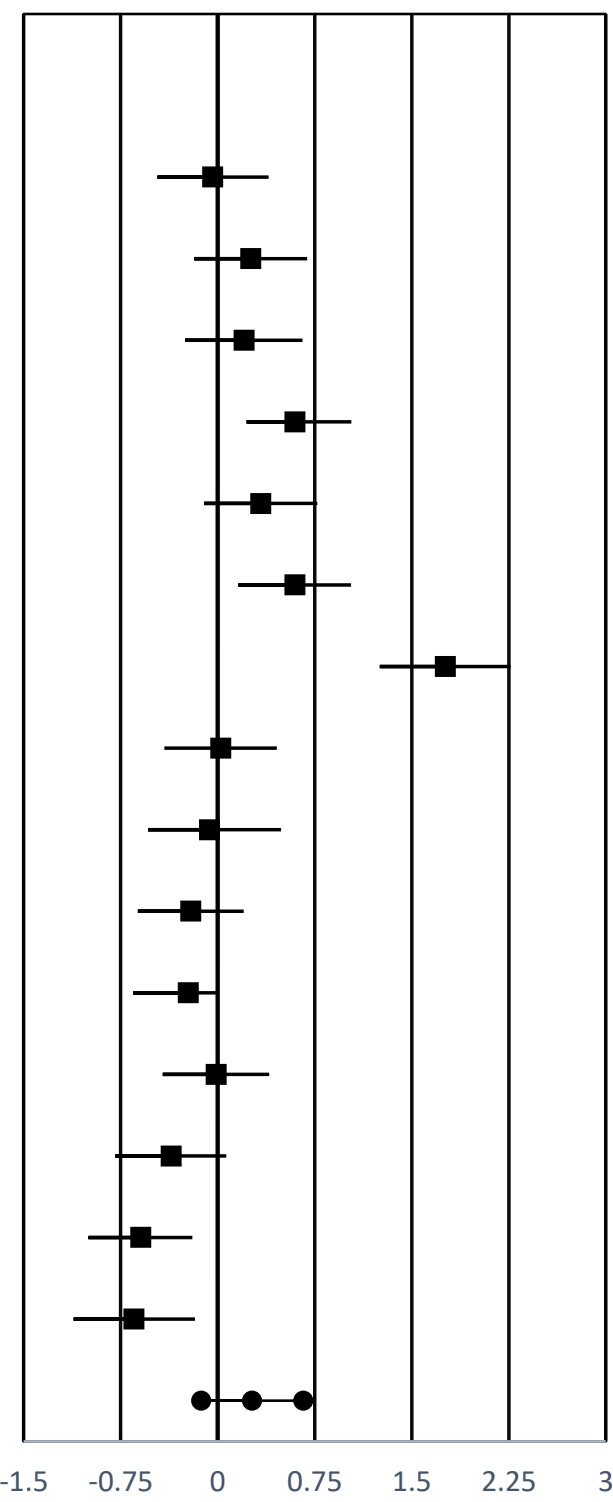

Case Advancement Odds 
Table 13 presents the average effect size estimate for each variable moderated by the sample year(s) of the study. Sample year was also used as a continuous variable that was centered around its mean. It is possible changes over time may influence the association between correlates and case advancement. Results from the analysis show sample year $(\mathrm{p}>.05)$ was nonsignificant and the effects were not moderated by study sample year(s) and results remained unchanged. 
Table 13. Multivariate meta-analysis for case advancement moderated by sample year.

\begin{tabular}{|c|c|c|c|c|c|}
\hline Independent Variable & $\begin{array}{l}\text { Log. Odds } \\
\text { Ratio }\end{array}$ & $\begin{array}{l}\text { Odds } \\
\text { Ratio }\end{array}$ & $\begin{array}{c}\text { Standard } \\
\text { Error }\end{array}$ & $\begin{array}{l}\text { Ci.Lb } \\
(95 \%)\end{array}$ & $\begin{array}{l}\text { Ci.Ub } \\
(95 \%)\end{array}$ \\
\hline Intercept & .2505 & 1.28 & .3181 & -.3730 & .8740 \\
\hline \multicolumn{6}{|l|}{ Suspect blameworthiness } \\
\hline Resisted & -.1419 & .87 & .3325 & -.7936 & .5099 \\
\hline Injured & .3781 & 1.46 & .3324 & -.2734 & 1.0296 \\
\hline \multicolumn{6}{|l|}{$\begin{array}{l}\text { Protection of the } \\
\text { community }\end{array}$} \\
\hline Weapon & .2155 & 1.24 & .3395 & -.4499 & .8810 \\
\hline \multicolumn{6}{|l|}{ Practical constraints } \\
\hline Physical evidence* & .5299 & 1.70 & .3329 & .1725 & 1.1823 \\
\hline Report time & .4231 & 1.53 & .3360 & -.2354 & 1.0816 \\
\hline Witness* & .7870 & 2.20 & .3311 & .1380 & 1.4360 \\
\hline Cooperated $* * *$ & 1.7795 & 5.93 & .4003 & .9949 & 2.5640 \\
\hline \multicolumn{6}{|l|}{ Perceptual shorthand } \\
\hline Non-stranger & -.3549 & .70 & .3384 & -1.0180 & .3083 \\
\hline Intimate partner & -.4745 & .62 & .3624 & -1.1848 & .2358 \\
\hline Suspect age & -.1226 & .89 & .3316 & -.7726 & .5274 \\
\hline Victim age & .1835 & .83 & .3209 & -.8124 & .4454 \\
\hline Suspect race & -.2793 & .76 & .3292 & -.9245 & .3660 \\
\hline Victim race & .0256 & 1.03 & .3171 & -.5959 & .6471 \\
\hline Credibility** & -.6148 & .54 & .3081 & -1.2187 & -.1208 \\
\hline Victim substance use ** & -.6323 & .53 & .3601 & -1.3380 &.-1334 \\
\hline \multicolumn{6}{|l|}{ Moderator } \\
\hline Sample year & -.0076 & .99 & .0110 & -.0291 & .0139 \\
\hline \multicolumn{6}{|l|}{ Level 1} \\
\hline ESE Variance & .2921 & & & & \\
\hline \multicolumn{6}{|l|}{ Level 2} \\
\hline Study variance & 1068 & & & & \\
\hline $\mathrm{QE}$ & $996.45^{* * * *}$ & & & & \\
\hline QM & $165.72 * * *$ & & & & \\
\hline$N$ (ESEs) & 746 & & & & \\
\hline
\end{tabular}


Table 14 presents the average effect size estimates on charging moderated by study sample size. The analysis included study sample size to determine if larger samples affected the relationship between variables and case advancement. The study sample was dichotomized $(\mathrm{N}>325=1)$ based on the sample mean across both police and prosecutor studies and aimed to examine whether study sample had a moderating effect. Results showed study sample size $(\mathrm{p}>.05)$ was nonsignificant, the effects were not moderated by study sample size, and smaller samples did not deviate significantly from larger samples. Finally, the model including both sample year and sample size was analyzed. Results showed both study sample year $(\mathrm{p}>.05)$ and sample size $(\mathrm{p}>.05)$ have no moderating effect. 
Table 14. Multivariate meta-analysis for case advancement moderated by sample size

\begin{tabular}{|c|c|c|c|c|c|}
\hline Independent Variable & $\begin{array}{l}\text { Log. Odds } \\
\text { Ratio }\end{array}$ & $\begin{array}{l}\text { Odds } \\
\text { Ratio }\end{array}$ & $\begin{array}{l}\text { Standard } \\
\text { Error }\end{array}$ & $\begin{array}{l}\text { Ci.Lb } \\
(95 \%)\end{array}$ & $\begin{array}{l}\text { Ci.Ub } \\
(95 \%)\end{array}$ \\
\hline Intercept & .2900 & 1.34 & .2034 & -.1086 & .6886 \\
\hline \multicolumn{6}{|l|}{ Suspect } \\
\hline \multicolumn{6}{|l|}{ blameworthiness } \\
\hline Resisted & -.0540 & .95 & .2190 & -.4832 & .3753 \\
\hline Injured & .2688 & 1.31 & 2230 & -.1682 & .7059 \\
\hline \multicolumn{6}{|l|}{$\begin{array}{l}\text { Protection of the } \\
\text { community }\end{array}$} \\
\hline Weapon & .1990 & 1.22 & 2307 & -.2532 & .6511 \\
\hline \multicolumn{6}{|l|}{ Practical constraints } \\
\hline Physical evidence* & .5618 & 1.75 & 2230 & .1247 & 9989 \\
\hline Report time & .3562 & 1.43 & 2244 & -.0836 & .7960 \\
\hline Witness** & .5797 & 1.79 & 2219 & .1448 & 1.0147 \\
\hline Cooperated $* * *$ & 1.7671 & 5.85 & .2570 & 1.2633 & 2.2708 \\
\hline \multicolumn{6}{|l|}{ Perceptual shorthand } \\
\hline Non-stranger & .0669 & 1.07 & 2211 & -.3664 & .5003 \\
\hline Intimate partner & -.0995 & .91 & .2418 & -.5734 & .3744 \\
\hline Suspect age & -.2296 & .80 & .2164 & -.6537 & .1945 \\
\hline Victim age & -.2249 & .80 & 2109 & -.6383 & .1885 \\
\hline Suspect race & -.2832 & .75 & .2231 & -.7205 & .1540 \\
\hline Victim race & .0041 & 1.00 & 2091 & -.4058 & .4139 \\
\hline Credibility** & -.5687 & .57 & 2055 & -.9716 & -.1659 \\
\hline Victim substance & -.6123 & .54 & .2414 & -1.8053 & -.1493 \\
\hline \multirow{2}{*}{\multicolumn{6}{|c|}{$\begin{array}{l}\text { use }{ }^{* *} \\
\text { Moderator }\end{array}$}} \\
\hline & & & & & \\
\hline Sample size & -.0555 & .95 & .0688 & -.1903 & .0793 \\
\hline \multicolumn{6}{|l|}{ Level 1} \\
\hline ESE Variance & .1812 & & & & \\
\hline \multicolumn{6}{|l|}{ Level 2} \\
\hline Study variance & .0450 & & & & \\
\hline $\mathrm{QE}$ & $1239.33 * * *$ & & & & \\
\hline QM & $269.21 * * *$ & & & & \\
\hline$N$ (ESEs) & 746 & & & & \\
\hline
\end{tabular}
*Statistically significant at $\mathrm{p}<.05, * *$ statistically significant at $\mathrm{p}<.01, * * *$ statistically significant at $\mathrm{p}<.001 . N$ denotes the total number of effect size estimates. QE displays the test results for effect size heterogeneity, while QM displays the test results for moderator heterogeneity. 


\section{Police and Prosecutor Study Sample Publication Bias}

Five steps were used to assess publication bias within the combined police and prosecutor sample. First, publication bias was tested by funnel plot asymmetry (Begg \& Mazumdar, 1994), and visual inspection of Figure 9 showed symmetry. Next, the trimand-fill procedure was used and imputed several effect sizes. Figure 10 presents trimand-fill procedure results. The adjusted model estimate after applying the trim-and-fill procedure was .4415 . Imputed studies were likely the result of most credibility effect sizes being negatively correlated with arrest rather than publication bias.. Third, Egger's regression test $(\mathrm{z}=-.3998, \mathrm{p}=.6893)$ was nonsignificant and indicates no clear evidence of publication bias. Fourth, Rosenthal's classic fail-safe $N$ test $(N=62,376)$ were robust and would require many studies for the mean effect size to become nonsignificant. Similarly, Orwin's fail-safe $N$ test $(N=11,989)$ were robust and would require a sizeable number of missing effect sizes to nullify the mean effect. Tests for publication bias indicate the sample was protected against potential bias. 
Figure 9. Funnel plot for case advancement.

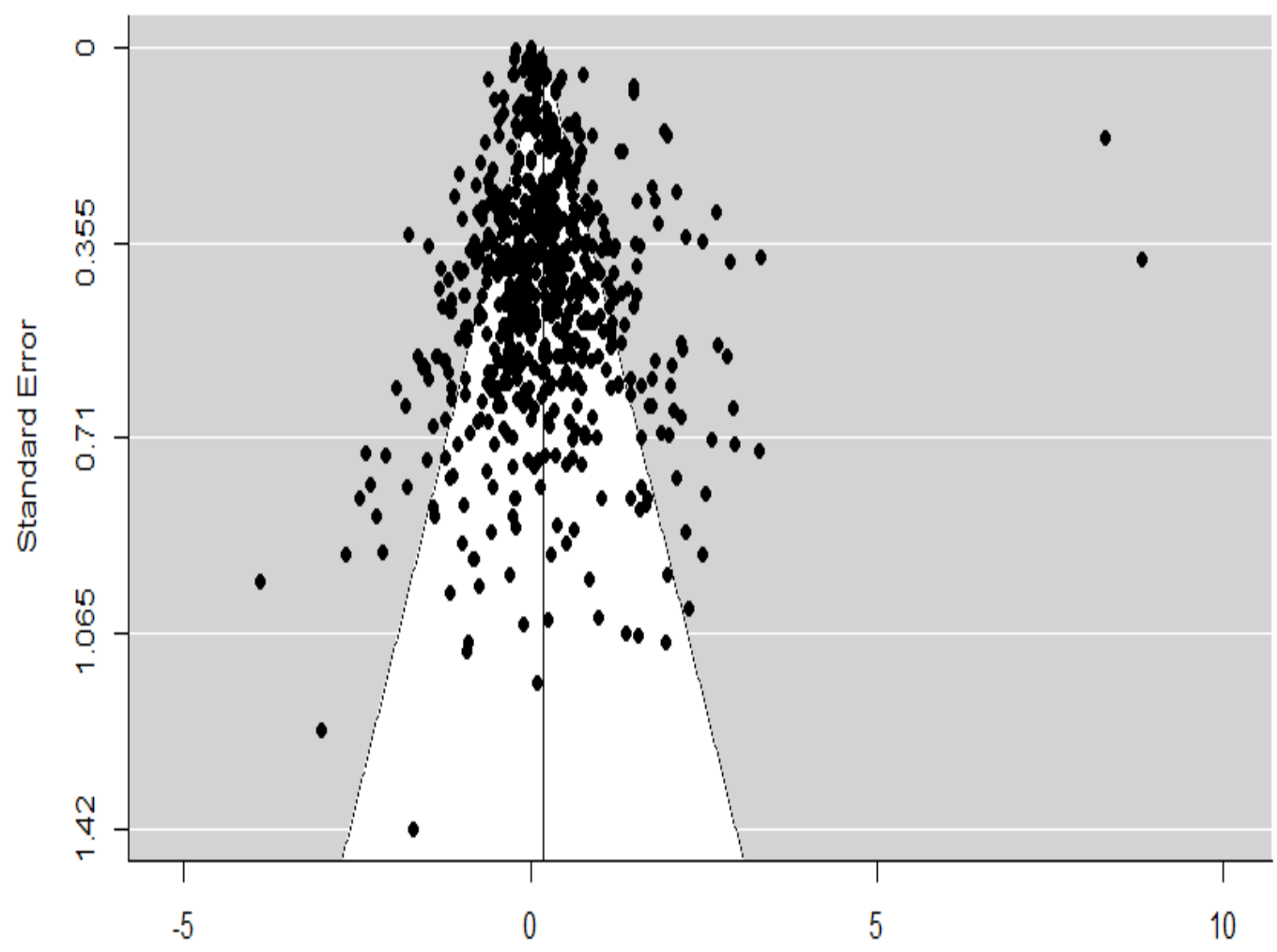

Observed Outcome 
Figure 10. Trim-and-fill procedure for case advancement.

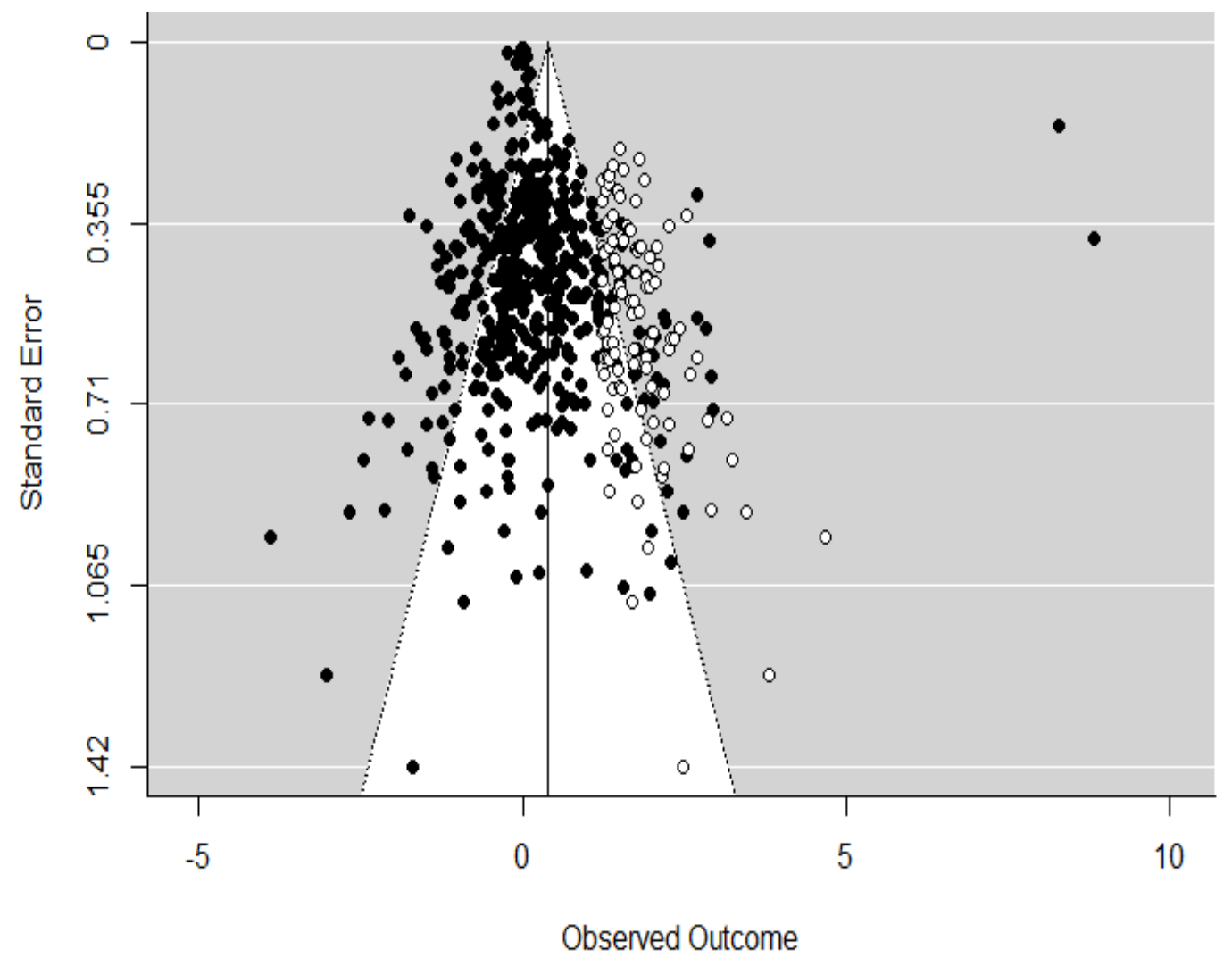




\section{Chapter Summary}

This chapter presented results for three meta-analyses on practitioner decisionmaking in sexual assault cases. Most studies were published after 2000 in peer-reviewed journals, took place in the United States, used samples of adolescent/juvenile and adult victims, and often data collected in multiple jurisdictions. These meta-analyses estimated the magnitude and direction of focal concerns variables on practitioner decision-making, evaluated potential moderators, and assessed publication bias.

While some effects were consistent across each decision point (e.g., victim cooperation), the size of the effects and statistical significant varied at the arrest and charging stages. At arrest, availability of physical evidence, victim cooperation, and nonstranger assaults had the greated effect on odds of arrest. In addition, questions about a victim's perceived credibility and substance use prior to the assault decreased odds of arrest. At charging, witness(es) to the assault and victim cooperation had the greatest effects on odds of charging and were statistically significant. Additionally, questions about a victim's perceived credibility decreased odds of charging and was statistically significant. For case advancement, availability of physical evidence, witness(es) to the

assault, and victim cooperation had the greatest effects on odds of case advancement and were statistically significant. Additionally, questions about a victim's perceived credibility and substance use prior to the assault decreased odds of arrest and were statistically significant. Indeed, availability of physical evidence, victim cooperation, witness(es) to the assault, questions about a victim's perceived credibility, and substance use prior to the assault had the most consistent and robust effects on decision-making. Lastly, moderator analyses were conducted to assess whether sample year and sample 
size potentially influenced the relationship between variables and outcomes. Modertaor analyses results showed sample year and sample size did not moderate the relationships between predictors and outcomes.

To assess the potential problem of publication bias, funnel plots, the trim-and-fill procedure, Egger's regression test, and fail-safe $N$ s were performed to estimate potential bias. These procedures were used in the police sample, prosecutor sample, and the combined sample. First, in all three sample, results from Orwin's fail-safe $N$ and Rosenthal's fail-safe $N$ found all three samples robustly protected against potential publication bias and a substantial number of missing studies are required to meaningfully affect effect size estimates stengh and signifincance. Second, Egger's regression tests were nonsignificant and detected no evidence of publication bias in all three samples. Third, while visual inspect of funnel plots revealed no evidence of publication in the police sample, visual examination of funnel plots for prosecutor and the combined sample revealed asymmetry and potential publication bias. As such,the trim-and-fill procedure was used to impute studies to create symmetry and visually display potentially missing studies, which was completed for both the police and combined sample. Visually inspection of the funnel plots and trim-and-fill procedure resulted in evidence of potential publication bias in the prosecutor and combined samples. This evidence of publication bias could be because of unpublished reports, studies missed during the search process, or study authors selectively publishing effects. Although Egger's regression test and failsafe $N$ s indicated no publication bias within the samples, results should be interpreted with some caution. 


\section{CHAPTER 5}

\section{DISCUSSION}

The focal concerns framework has been prevalent within the criminal justice decision-making literature for decades (Crow \& Adrion, 2011; Hartley et al., 2007; Steffensmeier et al., 1998; Ulmer \& Johnson, 2004). Additionally, the framework has been used to explain prosecutor, and more recently, police decision-making in sexual assault cases. That said, measurement inconsistencies of some victim and case characteristics have motivated scholars to apply more consistent measures to practitioner decisions in sexual assault cases. Research by O'Neal and Spohn (2017) proposed variables to operationalize focal concerns concepts, which could help reduce measurement inconsistencies and offer guidance to standardize measurement in future studies. Despite measurement differences across studies, many studies have used common correlates that fit with the focal concerns measures proposed by O’Neal and Spohn. Yet, no study has conducted a meta-analytic review to examine the magnitude and direction these variables have on practitioner decision-making. As a result, I sought to assess the applicability of focal concerns on decision-making in sexual assault cases and to evaluate the effects of focal concerns variables on decision-making, differentiate the key correlates of arrest and charging, and identify which correlates are most important to case advancement using meta-analysis.

The main goal of meta-analysis is to help estimate the size and direction of effect sizes across individual studies rather than determine statistical significance (see Haidich, 
2010; Hedges \& Olkin, 1980; Sullivan \& Feinn, 2012). Thus, my goal was to summarize effect size estimates for correlates of arrest and charging and not focus primarily on statistical significance. To accomplish this, I adapted work by O'Neal and Spohn (2017) and expanded on their operationalization of focal concerns variables to assess how focal concern variables interact to affect practitioner decision-making. I classified common correlates of police and prosecutor decision-making into suspect blameworthiness, protection of the community, practical constraints, and perceptual shorthand. The study intended to evaluate these concepts, synthesize literature, and assess the empirical status of focal concerns as it relates to sexual assault cases and police and prosecutor discretion. Specifically, I aimed to contribute by (1) producing a systematic meta-analytic literature review of studies assessing correlates of police and prosecutor decision-making in sexual assault cases, (2) estimating the magnitude and direction of victim and case characteristics on decision-making, (3) examining whether the effects of victim and case characteristics differ between police and prosecutor decision-making, (4) combining police and prosecutor decision-making to determine which victim and case characteristics are most important to case advancement, and (5) assessing the applicability of focal concerns to understand case advancement among studies that examined both police and prosecutor decisions in sexual assault cases. To accomplish these goals, three primary meta-analyses were conducted. The first meta-analysis estimated effect sizes for arrest, the second estimated effect sizes for charging, and the third combined both decisions and examined case advancement. The analyses indicated overall empirical support for the focal concerns framework as applied to practitioner decision-making and many correlates robustly effected discretion at both stages. 


\section{Summary of Current Findings}

At the arrest stage, the analysis produced robust effect sizes across many variables. First, practical constraint variables demonstrated the strongest effects. For instance, practical constraints contained two of the three strongest effect sizes. Victims believed to be cooperating during the investigation substantially and significantly increased odds of arrest by $490 \%$ and availability of physical evidence increased odds of

arrest by $72 \%$. These effects are likely because of the importance of physical evidence in identifying suspects and corroborating victim accounts of sexual assaults. In addition, a prompt report of victimization to police increased odds of arrest by $28 \%$ and witness(es) to the assault increased odds of arrest by $16 \%$ but were nonsignificant. Second, for perceptual shorthand, non-stranger assaults increased odds of arrest by $60 \%$ and was significant. Intimate partner assaults increased odds of arrest by $31 \%$ but was nonsignificant. This was unsurprising given the importance of identifying and locating suspects and the ability to readily identify suspects of intimate partner and non-stranger assaults (Spencer \& Stith, 2020). Variables related to a victim's perceived credibility indicated a statistically ignificant $38 \%$ decrease in odds of arrest. In addition, victim substance use prior to the assault was significant and decreased odds of arrest by $42 \%$. These findings were expected because police often ascribe to rape myths and have misconceptions about "true victims", which involves victim behaviors prior, during, or after the assault (Estrich, 1987). Additionally, victim age decreased odds of arrest by $22 \%$, suspect age decreased odds of arrest by $20 \%$, non-White suspects decreased odds of arrest by $32 \%$, and non-White victims decreased odds of arrest by $3 \%$, but all were nonsignificant. When a suspect was non-white, odds of arrest decreased by $32 \%$ and is 
opposite of the expected direction (Steffensmeier et al., 1998). However, research has found similar results when examining the way victim and suspect race/ethnicity interact and that the legal system's response will differ based on the victim/suspect/racial/ethnic dyad (Lafree, 1989; O’Neal et al., 2019). These studies argued that the legal system allocates fewer resources to cases involving minories, which is supported by the current findings that cases involving non-White offenders and victims were less likely to results in arrest. Third, for suspect blameworthiness, victim resistance (e.g., verbal, physical, or both) increased odds of arrest by $10 \%$ and victim injury increased odds of arrest by $15 \%$. Lastly, protection of the community was assessed using suspect weapon use, which increased odds of arrest by $26 \%$.

At charging, practical constraints again had the greatest effect on decisionmaking. For instance, a victim believed to be cooperating increased odds of charging by $474 \%$ and witness(es) presence increased odds of charging by $119 \%$ and were both statistically significant. This corresponds with prior research (Kelley et al., 2021) and highlights the importance of victim testimony to determine probable cause. In addition, availability of physical evidence increased odds of charging by $75 \%$ and a prompt report of victimization increased odds of charging by $47 \%$. Perceptual shorthand variables had the second greatest effects on charging. Non-stranger assaults decreased odds of charging by $31 \%$ and intimate partner assaults decreased charging by $39 \%$ and both were nonsignificant. These findings are also consistent with prior research that demonstrates practitioners believe "true victims" are assaulted by strangers (Estrich, 1987) and that cases are more likely to receive additional prosecutorial resources when the victim is a stranger (Bachman, 1998). Further, sexual assault cases that mentioned one variable 
known to affect credibility significantly reduced odds of charging by $48 \%$. Victim substance use prior to the assault also decreased odds of charging by $48 \%$. These findings were expected given research has found practitioners often endorse rape myths, that misconceptions negatively impact decision-making, and that prosecutors focus on victim behaviors prior, during, and after the sexual assault (Estrich, 1987; O'Neal et al., 2019; Tellis \& Spohn, 2008). Victim age decreased odds of charging by $17 \%$, suspect age decreased odds of charging by $14 \%$, and suspect race decreased odds charging by $29 \%$. Like arrest, non-White suspects had 29\% fewer odds of being charged, which is possibly due to fewer criminal-legal resources being allocated to cases involving non-Whites and practitioners may afford less effort when processing cases involving minorities (Kelley et al., 2021). In addition, victim race decreased odds of charging by $1 \%$. For suspect blameworthiness, victim injury increased odds of charging by $40 \%$. Victim resistance, however, affected charging in the opposite expected direction and decreased odds of charging by $11 \%$. This is likely due to prosecutors relying on additional factors such as victim injury, witness(es), offender weapon use, and physical evidence when determining to accept a case. Lastly, the measure of the need for protection of the community, offender weapon use, increased the odds of charging by $23 \%$.

The results for arrest and charging share similarities, however, some differences were detected in both the size and direction of effect sizes. First, practical constraints produced robust effects for both police and prosecutor decision-making. For instance, victim cooperation had a large effect on arrest and charging and increased arrest by $490 \%$ and charging by $474 \%$. Similarly, the availability of physical evidence increased odds of arrest by $72 \%$ and charging by $75 \%$. Still, the impact of witness(es) availability was 
substantially different. Indeed, a witness(es) present increased arrest by $16 \%$ and charging by $119 \%$. A prompt report of victimization increased the odds of arrest by $28 \%$ and increased the odds of charging by $47 \%$. Greater differences were seen across outcomes regarding perceptual shorthand, specifically victim-offender relationship variables. Non-stranger assaults increased odds of arrest by $60 \%$, whereas non-stranger assaults decreased odds of charging by $31 \%$. Likewise, intimate partner assaults increased odds of arrest by $31 \%$ and decreased odds of charging by $39 \%$. A victim's perceived credibility and substance use prior to the assault had similar effects on decision-making. When a victim's credibility was questioned, odds of arrest decreased $38 \%$ and odds of charging decreased $48 \%$. Similarly, victim substance use prior to the assault decreased odds of arrest by $42 \%$ and decreased odds of charging by $48 \%$. No differences in effects were found between arrest and charging for victim and suspect demographics, although suspect age, victim age, non-White suspects, and non-White victims were associated with decreased odds of arrest and charging. For suspect blameworthiness, the impact of victim resistance and victim injury were different across outcomes. For instance, victim resistance increased odds of arrest by $10 \%$ but decreased odds of charging by $11 \%$. The effect of victim injury were stronger on charging. Specifically, victim injury increased the odds of arrest by just $15 \%$ but increased odds of charging by $40 \%$. Finally, protection of the community, suspect weapon use increased odds of arrest by $26 \%$ and increased odds of charging by $23 \%$.

The third analysis combined outcomes to explore the effects of variables on case advancement. Overall, practical constraint variables had the greatest effect on case advancement and odds a suspect would be arrested and charged. In fact, practical 
constraints had the three most robust effect size estimates. Specifically, a victim believed to be cooperating increased odds of advancement by $481 \%$, witness(es) presence increased odds of advancement by $81 \%$, and availability of physical evidence increased odds of advancement by $81 \%$ and were each statistically significant. Additionally, a prompt report of victimization increased odds of advancement by $40 \%$. Several perceptual shorthand variables had modest effects on case advancement. Of these variables, a victim's perceived credibility decreased odds of advancement by $45 \%$, and substance use prior to the assault decreased odds of advancement by $47 \%$. Indeed, results for victim credibility and substance alcohol use suggests practitioners are often influenced by rape stereotypes that reduce the odds of case advancement. Non-stranger stranger assaults increased odds of advancement by $2 \%$ and intimate partner assaults decreased odds of advancement by $6 \%$. Victim age, suspect age, suspect race, and victim race each decreased odds of advancement. Cases with older victims decreased odds of advancement by $19 \%$, cases with older suspects decreased odds of advancement by $20 \%$, case involving non-White suspects had $30 \%$ fewer odds of case advancement, and cases involving non-White victims had 3\% fewer odds of advancement. For suspect blameworthiness, victim injury increased case advancement by $29 \%$, and victim resistance decreased advancement by $3 \%$. Finally, for protection of the community, suspect weapon use increased case advancement by $22 \%$. In sum, these results suggest focal concerns is a viable framework to explain police and prosecutor decision-making in sexual assault cases. 


\section{Policy Implications}

Findings from these analyses highlight important avenues to inform policy and improve practitioner responses to victims of sexual assault. First, training is needed to improve practitioner (e.g., police, prosecutor) perceptions about victims and knowledge of victim trauma. Prior evaluations of police training have been shown to improve officer perceptions of victims and knowledge of victim trauma. For instance, research has shown training may effectively reduce attributions of blame towards victims (Darwinkel et al., 2013; Tidmarsh et al., 2020), reduce rape myth acceptance (B. Campbell et al., 2019; Murphy \& Hine, 2019), and improve knowledge of trauma informed investigative techniques (B. Campbell et al., 2019; Franklin et al., 2019; Lonsway et al., 2001). In addition, training may help reduce officers' assessments of victim credibility and improve their knowledge about the usefulness of forensic evidence. This also suggests officers may rely on additional factors during the decision-making process and rely less on evaluations of victim credibility (B. Campbell et al., 2015). Moreover, I was unable to locate any prosecutor training evaluations on the topic of sexual assault. Based on findings from my meta-analytic review, prosecutors rely equally on evaluations of victim credibility and extralegal variables during the decision-making process. Police training evaluations have detected positive improvements among police samples across several outcomes, and it is reasonable to hypothesize prosecutors may equally benefit from attending sexual assault training courses. Thus, findings suggest training may be an effective means to advance police sexual assault training and to encourage future researchers to design, implement, and evaluate prosecutor training on sexual assault. Specifically, there are four primary ways to enhance training. 
First, victim cooperation expressed the greatest effect on decision-making across all models. Thus, training should be aimed at facilitating and maintaining victim cooperation throughout the legal process. Sexual assault training programs should include educating practitioners on victim-centered and trauma-informed techniques throughout investigation and prosecution, specifically when conducting initial and follow-up interviews. Applying victim-centered and trauma-informed techniques may reduce instances of secondary trauma and improve victim engagement (see B. Campbell et al., 2020; Tidmarsh et al., 2020).

Second, availability of physical evidence substantially affects each decisionmaking stage, which stresses the importance practitioners place on physical evidence during the decision-making process. Thus, practitioners should be offered training about the collection and processing of physical evidence at crime scenes and enhancing the utility of forensic evidence. Training officers on how to properly collect and process evidence may help establish probable cause to arrest and secure evidence helpful for prosecution. Additionally, training curriculums could incorporate information on sexual assault kits and stress the benefits of collecting and testing kits. Indeed, recent work has demonstrated the importance of sexual assault kit processing as a useful tool for practitioners. The recent push to process sexual assault kits has also established links between offenders to multiple unsolved sexual assaults. These offenders not only commit sexual violence but other various violent and property crimes after eluding arrest and prosecution. Lovell et al. (2020) analyzed cases of previously untested sexual assault kits and found undetected offenders commit future felonies. In fact, Lovell and colleagues (2020) found offenders commit an average of 7.4 felonies before being apprehended for 
their latest sexual offense. That said, educating practitioners about the significance of processing physical evidence and sexual assault kits could reduce sexual offenses as well as prevent future property and violent crimes.

Third, and more importantly, training should also focus on improving the likelihood of making an arrest and charging when physical evidence is unavailable in a sexual assault case. When physical evidence is not available, practitioners have often relied on victim credibility attributes and rape myths to make decisions about wich cases do - and do not - move forward (B. Campbell et al., 2015). However, research has pushed for training focusing on overcoming consent defenses put forth by suspects, and documenting how trauma affects victims' emotional and cognitive reactions to sexual assault (R. Campbell et al., 2012). Both aspects of training can assist in corroborating victim allegations and educating jurors about the dangers of relying on rape myths when making decisions in sexual assault cases.

Fourth, evaluations of victim credibility and substance use prior to the assault greatly decreased case advancement, and provided evidence rape myths impact arrest and charging decisions across studies. Additional training is necessary to educate practitioners on rape myths and dispel misconceptions about sexual assault cases and victims. For instance, my analysis indicated victim injury, suspect weapon use, victim credibility, and victim substance use prior to the assault impact arrest and charging decisions. Thus, training practitioners about rape myths may improve their knowledge of sexual assault cases and victims and help reduce victim-blaming and reliance on an assessment of victim credibility when making decisions to advance cases. A recent statewide training in Kentucky implemented these recommendations in a comprehensive 
40-hr sexual assault training course, which covered rape myth acceptance, the use of physical evidence in investigations, dynamics of sexual assault, trauma-informed investigations, and victim interviews. An evaluation of this training revealed positive short-term and long-term improvements in knowledge of trauma-informed practices, knowledge of Kentucky laws, and perceptions of victims (B. Campbell et al., 2020). Creating and implementing similar training programs for prosecutors could be beneficial in improving prosecutors' perceptions of victims and knowledge of trauma informed responses.

\section{Limitations}

Though this study provides several contributions to the literature, there are a few limitations worth noting. First, some studies might have been missed during the search strategy. In addition, publication bias was pontentially detected in the prosecutor and combined samples, however the imputed effect sizes were likely the result of most credibility effect sizes being negatively correlated with arrest rather than publication bias. Further, these tools assessed bias using results from two-level meta-analysis models, and should be interpreted with caution given the mutlilevel nature of the data.That said, future meta-anlaysis should widen searches to include additional databases, specifically databases that include studies from other fields closely related criminal justice. Publication bias may also be addressed by scholars publishing results regardless of effect size statistical signifance, strength, and direction of the relationship between key independent variables and outcome measures.

Second, some information was unavailable to assess certain moderators, such as the racial composition of both victims and suspects in some studies. Future studies should 
report demographic information so that future meta-analyses may assess the role of racial composition as a moderating variable. That said, in this study, supplemental moderator analyses did suggest uniformity across studies. Meanining, the sample year(s) and sample size had no moderating effects. Further, not enough studies reported effect sizes to evaluate the impact of physical assault on arrest and charging decisions, as suggested by O’Neal \& Spohn (2017). Thus, suspect weapon use was the only variable analyzed that measured protection of the community. When this physical assault is available to scholars, future meta-analyses could include it in their analyses.

\section{Future Research Directions}

To advance this line of research and address these limitations, future metaanalyses should examine additional decision-making outcomes. The decision to unfound has been studied by Ferguson \& Malouff (2016) using meta-analysis, however, other outcomes such as the ability of police to identify a suspect, the decision to interview a suspect, and practitioner judgements about victim cooperation during the investigative and prosecutorial processes warrant future evaluations. Exploring these decisions will help better understand multiple practitioner decision points in the process, as well as help understand factors that reduce victim engagement. Using meta-analysis to examine studies on victim cooperation may help identify factors impacting victim engagement and offer ways police training can target such factors and focus on methods known to facilitate victim engagement. Second, future research should reduce effect size heterogeneity by using uniform measures. This can be accomplished by following O'Neal and Spohn's (2017) operationalization of focal concerns variables and the measures that were presented in this study. In this way, measures across studies can be standardized and 
canimprove study replication and generalizability. Following these recommendations for the operationalization of variables can also increase the accuracy of effect size estimates, and improve our understanding of the association between focal concerns variables and practitioner decision-making in sexual assault cases.

Despite the minor limitations mentioned above, this meta-analytic significantly contributes to the literature by examining correlates of case advancement at multiple decision-making stages and assessing the applicability of focal concerns to explain practitioner discretion in sexual assault cases across studies. Thus, my findings identified the strongest correlates of practitioner decision-making and found empirical support for the application of the focal concerns framework in sexual assault cases. Variables for each focal concerns concept had sizeable effects on decision-making, however not all were statistically significant. Finally, moderator analyses using sample year and sample size did not significantly influence the relationship between focal concerns variables and arrest and charging decisions.

A future meta-analysis should take additional steps to assess moderating effects of focal concerns variables. First, an overall model without moderating variables. Second, a series of meta-regression models using a single moderator per model. Third, subgroup analyses using effect sizes for each focal concerns concept. In this way, scholars can capture whether effect sizes from specific focal concerns variables are significantly different and isolate the effects for each concept. 


\section{REFERENCES}

Albonetti, C. (1986). Criminality, prosecutorial screening, and uncertainty: Toward a theory of discretionary decision making in felony case processings. Criminology, 24(4), 623-644.

Albonetti, C. A. (1987). Prosecutorial discretion: The effects of uncertainty. Law \& Society Review, 21, 291-314.

Albonetti, C. (1991). An integration of theories to explain judicial discretion. Social Problems, 38(2), 247-266.

Alderden, M. A., \& Ullman, S. E. (2012a). Creating a more complete and current picture: Examining police and prosecutor decision-making when processing sexual assault cases. Violence Against Women, 18, 525-551.

Alderden, M. A., Ullman, S. E. (2012b). Gender difference or indifference? Detective decision making in sexual assault cases. Journal of Interpersonal Violence, 27, 3 22.

Alvarez, A., Bachman, R. (1996). American Indians and sentencing disparity: An Arizona test. Journal of Criminal Justice, 24, 549-561.

Andrews, D. A., Zinger, I., Hoge, R. D., Bonta, J., Gendreau, P., \& Cullen, F. T. (1990). Does correctional treatment work? A clinically relevant and psychologically informed meta-analysis. Criminology, 28(3), 369-404. 
Bachman, R. (1998). The factors related to rape reporting behavior and arrest: New evidence from the National Crime Victimization Survey. Criminal justice and behavior, 25(1), 8-29.

Beichner, D. \& Spohn, C. (2005). Prosecutorial charging decisions in sexual assault cases: Examining the impact of a specialized prosecution unit. Criminal Justice Policy Review, 16, 461-498.

Beichner, D. \& Spohn, C. (2012). Modeling the effects of victim behavior and moral character on prosecutors' charging decisions in sexual assault cases. Violence and Victims, 27, 3-24.

Bennett, T., Holloway, K., \& Farrington, D. P. (2007). Does neighborhood watch reduce crime? A systematic review and meta-analysis. Journal of Experimental Criminology, 2(4), 437-458.

Berlin, J.A., and Colditz, G.A. (1990). "A meta-analysis of physical activity in the prevention of coronary heart disease". American Journal of Epidemiology, 132, 612-628.

Booth, A., Sutton, A., \& Papaioannou, D. (2016). Systematic approaches to a successful literature review (2nd ed.). Thousand Oaks, CA: Sage.

Borenstein, M., Hedges, L. V., Higgins, J. P., \& Rothstein, H. R. (2011). Introduction to meta-analysis. John Wiley \& Sons.

Bouffard, J. A. (2000). Predicting type of sexual assault case closure from victim, suspect, and case characteristics. Journal of Criminal Justice, 28, 527-542. 
Brady, P. Q., \& Reyns, B. W. (2020). A focal concerns perspective on prosecutorial decision making in cases of intimate partner stalking. Criminal justice and behavior, 47(6), 733-748.

Braga, A. A., Papachristos, A. V., \& Hureau, D. M. (2014). The effects of hot spots policing on crime: An updated systematic review and meta-analysis. Justice Quarterly, 31(4), 633-663

Braga, A. A., \& Weisburd, D. L. (2012). The effects of focused deterrence strategies on crime: A systematic review and meta-analysis of the empirical evidence. Journal of Research in Crime and Delinquency, 49(3), 323-358.

Brind, J., Chinchilli, V.M., Severs, W.B., and Summy-Long, J. (1996). "Induced abortion as an independent risk factor for breast cancer: A comprehensive review and meta-analysis". Journal of Epidemiology and Community Health, 50, 481-496.

Brown, J. M., Hamilton, C., \& O'Neill, D. (2007). Characteristics associated with rape attrition and the role played by scepticism or legal rationality by investigators and prosecutors. Psychology, Crime \& Law, 13(4), 355-370.

Brownmiller, S. (1975). Against our will: Men, women, and rape. New York, NY: Fawcett Books.

Buchwald, E., Fletcher, P. R., \& Roth, M. (Eds.). (1993). Transforming a rape culture (p. 9). Minneapolis, MN: Milkweed Editions.

Burt, M. R. (1980). Cultural myths and supports for rape. Journal of Personality and Psychology, 38(2), 217-230. 
Campbell, B. A., Lapsey, D. S., \& Wells, W. (2020). An evaluation of Kentucky’s sexual assault investigator training: results from a randomized three-group experiment. Journal of Experimental Criminology, 16(4), 625-647.

Campbell, B. A., Menaker, T. A., \& King, W. R. (2015). The determination of victim credibility by juvenile and adult sexual assault investigators. Journal of Criminal Justice, 43,29-39.

Campbell, R. (2008). The psychological impact of rape victims' experiences with the legal, medical, and mental health systems. American Psychologist, 68, 702-717.

Campbell, R. (2012). The neurobiology of sexual assault: implications for first responders in law enforcement, prosecution, and victim advocacy. In NIJ Research for the RealWorld Seminar. Available at: https://www.ncjrs.gov/App/Publications/abstract.aspx?ID=263040

Campbell, R., Bybee, D., Townsend, S. M., Shaw, J., Karim, N., \& Markowitz, J. (2014). The impact of sexual assault nurse examiner programs on criminal justice case outcomes: A multi-site study. Violence Against Women, 20, 607-625.

Campbell, R., \& Fehler-Cabral, G. (2018). Why police “couldn't or wouldn't” submit sexual assault kits for forensic DNA testing: a focal concerns theory analysis of untested rape kits. Law \& Society Review, 52, 73-105.

Campbell, R., Wasco, S. M., Ahrens, C. E., Sefl, T., \& Barnes, H. E. (2001). Preventing the 'second rape:' Rape survivors' experiences with community service providers. Journal of Interpersonal Violence, 16, 1239-1259.

Chandler, S. M. \& Torney, M. (1981). The decisions and processing of rape victims through the criminal justice system. California Sociologist, 4(2), 155-169. 
Cheung, S. F., \& Chan, D. K. S. (2004). Dependent effect sizes in meta-analysis: Incorporating the degree of interdependence. The Journal of Applied Psychology, 89(5), 780-791.

Cheung, S. F., \& Chan, D. K. S. (2008). Dependent correlations in meta-analysis: The case of heterogeneous dependence. Educational and Psychological Measurement, $68,760-777$.

Cohen, J. 1988. Statistical Power Analysis for the Behavioral Sciences, 2nd Ed. New York: Routledge.

Cooper, H. (2017). Research synthesis and meta-analysis: A step-by-step approach (5th ed.). Thousand Oaks, CA: Sage.

Cooper, H., Hedges, L. V., \& Valentine, J. C. (Eds.). (2019). The handbook of research synthesis and meta-analysis. Russell Sage Foundation.

Crow, M. S., \& Adrion, B. (2011). Focal concerns and police use of force: Examining the factors associated with TASER use. Police Quarterly, 14, 366-387.

Cullen, F. T. (2005). The twelve people who saved rehabilitation: How the science of criminology made a difference: The American Society of Criminology 2004 Presidential Address. Criminology, 43(1), 1-42.

Cullen, F. T., Wright, J. P., \& Blevins, K. R. (Vol. Eds.). (2006). Taking stock: The status of criminological theory, advances in criminological theory (Vol. 15). New Brunswick, NJ: Transaction.

Darwinkel, E., Powell, M., \& Tidmarsh, P. (2013). Improving police officers’ perceptions of sexual offending through intensive training. Criminal justice and behavior, 40(8), 895-908. 
Denney, A. S., \& Tewksbury, R. (2013). How to write a literature review. Journal of Criminal Justice Education, 24(2), 218-234.

Egger, M. (1997). Bias in meta-analysis detected by a simple, graphical test. BMJ, 315, 629-634.

Estrich, S. (1987). Real rape: How the system victimizes women who say no. Cambridge, MA: Harvard University Press.

Farrington, D. P., \& Welsh, B. C. (2003). Family-based prevention of offending: A metaanalysis. Australian \& New Zealand Journal of Criminology, 36(2), 127-151.

Farrington, D. P., \& Welsh, B. C. (2008). Saving children from a life of crime: Early risk factors and effective interventions. New York: Oxford University Press.

Fleiss, J.L. (1993). "The statistical basis of meta-analysis". Statistical Methods in Medical Research, 2, 121-145.

Fleiss, J.L. and Berlin, J.A. (2009). "Effect sizes for dichotomous data". In Cooper, H., Hedges, L. and Valentine, J. The Handbook of Research Synthesis and MetaAnalysis (2nd Ed). New York: Russell Sage Foundation.

Franklin, T. W. (2013). Sentencing native Americans in US federal courts: An examination of disparity. Justice Quarterly, 30, 310-339.

Franklin, T. W. (2017). Sentencing outcomes in US district courts: Can offenders' educational attainment guard against prevalent criminal stereotypes?. Crime \& Delinquency, 63(2), 137-165.

Franklin, C. A., Garza, A. D., Goodson, A., \& Bouffard, L. A. (2020). Police perceptions of crime victim behaviors: A trend analysis exploring mandatory training and 
knowledge of sexual and domestic violence survivors' trauma responses. Crime \& Delinquency, 66(8), 1055-1086.

Franklin, T. W., \& Henry, T. K. S. (2020). Racial disparities in federal sentencing outcomes: Clarifying the role of criminal history. Crime \& Delinquency, 66(1), 332.

Frazier, P.A., \& Haney, B. (1996). Sexual assault cases in the legal system: Police, prosecutor, and victim perspectives. Law and Human Behavior, 20(6), 607-628.

Feild, H. S. (1978). Attitudes toward rape: A comparative analysis of police, rapists, crisis counselors, and citizens. Journal of personality and social psychology, 36(2), 156.

Ferguson, C. E., \& Malouff, J. M. (2016). Assessing police classifications of sexual assault reports: A meta-analysis of false reporting rates. Archives of sexual behavior, 45(5), 1185-1193.

Frohmann, L. (1991). Discrediting victims' allegations of sexual assault: Prosecutorial accounts of case rejections. Social Problems, 38, 213-226.

Frohmann, L. (1997). Convictability and discordant locales: Reproducing race, class, and gender ideologies in prosecutorial decision-making. Law and Society Review, 31, $531-555$.

Gaugler, J.E., Duval, S., Anderson, K.A., and Kane, R.L. (2007). Predicting nursing home admissions in the U.S: A meta-analysis. BMC Geriatrics, 7, 1-14.

Galton, E. R. (1975). Police processing of rape complaints: A case study. American Journal of Criminal Law, 4(1), 15-30. 
Geddes, J.R., and Lawrie, S.M. (1995). Obstetric complications and schizophrenia: A meta-analysis. The British Journal of Psychiatry. 167, 786-793.

Greenland, S. (1987). Quantitative methods in the review of epidemiologic literature. Epidemiological Reviews, 9, 1-30

Greenland, S. (1993). A meta-analysis of coffee, myocardial infarction, and coronary death. Epidemiology, 4, 366-374.

Gregory, J., \& Lees, S. (1996). Attrition in rape and sexual assault cases. The British Journal of Criminology, 36(1), 1-17.

Haddock, C.K., Rindskopf, D., and Shadish, W.R. (1998). "Using odds ratios as effect sizes for meta-analysis of dichotomous data: A primer on methods and issues". Psychological Methods, 3, 339-353.

Haidich, A. B. (2010). Meta-analysis in medical research. Hippokratia, 14, 1-29.

Hanson, R. K., \& Bussiere, M. T. (1998). Predicting relapse: A meta-analysis of sexual offender recidivism studies. Journal of Consulting and Clinical Psychology, 66(2), 348-362.

Hanushek, E.A., and Jackson, J.E. (1977). Statistical methods for social scientists. Orlando, FL: Academic Press Inc.

Hartley, R. D., Maddan, S., \& Spohn, C. (2007). Concerning conceptualization and operationalization: Sentencing data and the focal concerns perspective-A research note. Southwest Journal of Criminal Justice, 4, 58-78.

Hedges, L.V., and Olkin, I. (1985). Statistical methods for meta-analysis. London: Academic Press Inc. 
Heidt, J.M., Marx, B. P., \& Forsyth, J. P. (2005). Tonic immobility and childhood sexual abuse: Evaluating the sequela of rape-induced paralysis. Behavior Research and Therapy, 43, 1157-1171.

Higgins, G. E., Vito, G. F., \& Grossi, E. L. (2012). The impact of race on the police decision to search during a traffic stop: A focal concerns theory perspective. Journal of Contemporary Criminal Justice, 28(2), 166-183.

Higginson, A., Benier, K., Shenderovich, Y., Bedford, L., Mazerolle, L., \& Murray, J. (2018). Factors associated with youth gang membership in low- and middleincome countries: A systematic review. Campbell Systematic Reviews, 14(1), 1128.

Holleran, D., Beichner, D., \& Spohn, C. (2010). Examining charging agreement between police and prosecutors in rape cases. Crime \& Delinquency, 56(3), 385-413.

Holmes, B., \& D’Amato, C. (2020). Judicial and prosecutorial decision-making: Assessing the effects of race, gender, and age on federal downward sentencing departures, 2013-2016. Journal of Crime and Justice, 43(4), 449-466.

Hox, J. J. (2010). Multilevel analysis: Techniques and applications (2nd ed.). New York: Routledge.

Hunt, M. (1997). How science takes stock: The story of meta-analysis. New York: Russell Sage Foundation.

Hunter, J. E., \& Schmidt, F. L. (1990). Methods of meta-analysis. Newburk Park, CA: Sage Publications.

Hunter, J. E., \& Schmidt, F. L. (2004). Methods of meta-analysis: Correcting error and bias in research findings. Thousand Oaks, CA : Sage. 
Ishoy, G. A., \& Dabney, D. A. (2018). Policing and the focal concerns framework:

Exploring how its core components apply to the discretionary enforcement decisions of police officers. Deviant Behavior, 39(7), 878-895.

January, A. M., Casey, R. J., \& Paulson, D. (2011). A meta-analysis of classroom-wide interventions to build social skills: Do they work? School Psychology Review, 40, 242-256.

Johnson, B. D., Betsinger, S. (2009). Punishing the "model minority": Asian-American criminal sentencing outcomes in federal district courts. Criminology, 47, 10451090.

Johnson, B. D., DiPietro, S. M. (2012). The power of diversion: Intermediate sanctions and sentencing disparity under presumptive guidelines. Criminology, 50, 811-850.

Johnson, R.R., Klahm, C. F., \& Maddox, H. G. (2015). An exploratory analysis of time lapses in serving arrest warrants: A focal concerns and disproportional contact approach. Criminal Justice Review, 40, 470-487.

Jordan, J. (2004). Beyond belief? Police, rape and women's credibility. Criminal Justice, 4, 29- 59.

Kaiser, K. A., O’Neal, E. N., \& Spohn, C. (2017). "Victim refuses to cooperate”: A focal concerns analysis of victim cooperation in sexual assault cases. Victims \& Offenders, 12(2), 297-322.

Kelley, K.D., \& Campbell, R. (2013). Moving on or dropping out: Police processing of adult sexual assault cases. Women and Criminal Justice, 23(1), 1-18.

Kelley, S. M., Fleming, J. C., Acquaviva, B. L., Meeker, K. A., \& O’Neal, E. N. (2021). The Sexual Stratification Hypothesis and Prosecuting Sexual Assault: Is the 
Decision to File Charges Influenced by the Victim-Suspect Racial-Ethnic Dyad?. Crime \& Delinquency, 0011128721991821.

Kempf, K. L. (1993). The empirical status of Hirschi's control theory. In F. Adler \& W. S. Laufer (Eds.), New directions in criminological theory-Advances in criminological theory (Vol. 4, pp. 143-185). New Brunswick, NJ: Transaction.

Kempf, K. L. (2019). The status of Hirschi's social control theory after 50 years. In J. C.

Oleson \& B. J. Costello (Eds.), Fifty years of causes of delinquency: The criminology of Travis Hirschi-Advances in criminological theory (Vol. 25, pp. 161-208). New York: Routledge.

Kerstetter, W. (1990). Gateway to justice: Police and prosecutorial response to sexual assaults against women. Criminology, 81, 267-313.

Kingsnorth, R., MacIntosh, R., \& Wentworth, J. (1999). Sexual assault: The role of prior relationship and victim characteristics in case processing. Justice Quarterly, 16, $275-302$.

Kochel, T. R., Wilson, D. B., \& Mastrofski, S. D. (2011). Effects of suspect race on officers' arrest decisions. Criminology, 49(2), 473-512.

Koricheva, J., Gurevitch, J., \& Mengersen, K. (2013). Handbook of meta-analysis in ecology and evolution. Princeton, NJ: Princeton University Press.

Kreft, Ita, and Jan DeLeeuew. 1998. Introducing Multilevel Modeling. Thousand Oaks, CA: Sage.

LaFree, G. D. (1981). Official reactions to social problems: Police decisions in sexual assault cases. Social problems, 28(5), 582-594. 
Lasky-Su, J.A., Faraone, S.V., Glatt, S.J., and Tsuang, M.T. (2005). Meta-analysis of the association between two polymorphisms in the serotonin transporter gene and affective disorders. American Journal of Medical Genetics, 133, 110-115.

Lipsey, M. W., \& Wilson, D. B. (1998). Effective intervention for serious juvenile offenders: A synthesis of research. Thousand Oaks, CA: Sage.

Lipsey, M. W., \& Wilson, D. B. (2001). Practical meta-analysis. Thousand Oaks, CA: Sage.

Lisak, D., Gardiner, L., Nicksa, S. C., \& Cote, A. M. (2010). False allegations of sexual assault: An analysis of ten years of reported cases. Violence Against Women, 16, 1318-1334.

Lonsway, K. A. (2010). Trying to move the elephant in the living room: Responding to the challenge of false rape reports. Violence Against Women, 16, 1356-1371.

Lonsway, K. A., Welch, S., \& Fitzgerald, L. F. (2001). Police training in sexual assault response: Process, outcomes, and elements of change. Criminal justice and behavior, 28(6), 695-730.

Lösel, F. and Schmucker, M. (2005). The effectiveness of treatment for sexual offenders: A comprehensive meta-analysis. Journal of Experimental Criminology, 1, 117146.

Lovell, R., Huang, W., Overman, L., Flannery, D., \& Klingenstein, J. (2020). Offending histories and typologies of suspected sexual offenders identified via untested sexual assault kits. Criminal justice and behavior, 47(4), 470-486. 
Maier, S. L. (2008). “I Have Heard Horrible Stories...” Rape Victim Advocates' Perceptions of the Revictimization of Rape Victims by the Police and Medical System. Violence against women, 14(7), 786-808.

Martin, P.Y., \& Powell, R.M. (1994). Accounting for the "second assault:” Legal organizations' framing of rape victims. Law and Social Inquiry, 19(4), 853-890.

Marx, B. P., Forsyth, J. P., Gallup, G. G., Fuse, T., \& Lexington, J. M. (2008). Tonic immobility as an evolved predator defense: implications for sexual assault survivors. Clinical Psychology: Science and Practice, 15, 74-90.

Mazerolle, L., Bennett, S., Davis, J., Sargeant, E., \& Manning, M. (2013). Procedural justice and police legitimacy: A systematic review of the research evidence. Journal of Experimental Criminology, 9(3), 245-274

McGregor, M.J., Du Mont, J., \& Myhr, T.L. (2002). Sexual assault forensic medical examination: Is evidence related to successful prosecution? Annals of Emergency Medicine, 39,639-647.

Mitchell, O. (2005). A meta-analysis of race and sentencing research: Explaining the inconsistencies. Journal of Quantitative Criminology, 21, 439-466.

Morabito, M. S., Pattavina, A., \& Williams, L. M. (2019a). It all just piles up: Challenges to victim credibility accumulate to influence sexual assault case processing. Journal of interpersonal violence, 34(15), 3151-3170.

Morabito, M. S., Williams, L. M., \& Pattavina, A. (2019b). Decision making in sexual assault cases: replication research on sexual violence case attrition in the US. Lowell: University of Massachusetts Lowell, School of Criminology \& Justice Studies. 
O’Neal, E. N., \& Hayes, B. E. (2020). “A rape is a rape, regardless of what the victim was doing at the time": Detective views on how "problematic" victims affect sexual assault case processing. Criminal justice review, 45(1), 26-44.

O’Neal, E. N., Beckman, L. O., \& Spohn, C. (2019). The sexual stratification hypothesis: Is the decision to arrest influenced by the victim/suspect racial/ethnic dyad?. Journal of interpersonal violence, 34(6), 1287-1310.

O’Neal, E. N., Tellis, K., \& Spohn, C. (2015). Prosecuting intimate partner sexual assault: Legal and extra-legal factors that influence charging decisions. Violence Against Women, 21(10), 1237-1258.

O’Neal, E. N., \& Spohn, C. (2017). When the perpetrator is a partner: Arrest and charging decisions in intimate partner sexual assault cases-A focal concerns analysis. Violence against women, 23(6), 707-729.

Orwin, R. G. (1983). A fail-safe N for effect size in meta-analysis. Journal of educational statistics, 8, 157-159.

Paternoster, R. (1987). The deterrent effect of the perceived certainty and severity of punishment: A review of the evidence and issues. Justice Quarterly, 4(2), 173217.

Piquero, A. R., Jennings, W. G., Farrington, D. P., Diamond, B., \& Gonzalez, J. M. R. (2016). A meta-analysis update on the effectiveness of early self-control improvement programs to improve self-control and reduce delinquency. Journal of Experimental Criminology, 12(2), 249-264.

Pratt, T. C., \& Cullen, F. T. (2000). The empirical status of Gottfredson and Hirschi's general theory of crime: A meta-analysis. Criminology, 38(3), 931-964. 
Pratt, T. C., \& Cullen, F. T. (2005). Assessing macro-level predictors and theories of crime: A meta-analysis. Crime and Justice, 32, 373-450.

Pratt, T. C., Cullen, F. T., Blevins, K. R., Daigle, L. E., \& Madensen, T. D. (2006). The empirical status of deterrence theory: A meta-analysis. In F. T. Cullen, J. P.

Wright, \& K. R. Blevins (Eds.), Taking stock: The status of criminological theoryAdvances in criminological theory (Vol. 15). New Brunswick, NJ: Transaction.

Pratt, T. C., Cullen, F. T., Sellers, C. S., Winfree, L. T., Madensen, T. D., Daigle, L. E., ... Gau, J. M. (2010). The empirical status of social learning theory: A metaanalysis. Justice Quarterly, 27(6), 765-802

Pratt, T. C., Turanovic, J. J., Fox, K. A., \& Wright, K. A. (2014). Self-control and victimization: A meta-analysis. Criminology, 52(1), 87-116.

Raudenbush, S. W., \& Bryk, A. (2002). Hierarchical linear models: Applications and data analysis methods. Thousand Oaks, CA: Sage.

Rosenthal, R. (1979). The file drawer problem and tolerance for null results. Psychological Bulletin, 86, 638-641.

Schmucker, M., \& Losel, F. (2015). The effects of sexual offender treatment on recidivism: An international meta-analysis of sound quality evaluations. Journal of Experimental Criminology, 11(4), 597-630

Scott, H. S., \& Beaman, R. (2004). Demographic and situational factors affecting injury, resistance, completion, and charges brought in sexual assault cases: what is best for arrest?. Violence and Victims, 19(4), 479-494.

Smith, J. D. A. (2005). The Investigation of Rape Complaints: Variables that Best Predict Arrest (Doctoral dissertation). 
Snodgrass, G. M., Rosay, A. B., \& Gover, A. R. (2014). Modeling the referral decision in sexual assault cases: An application of random forests. American Journal of Criminal Justice, 39(2), 267-291.

Spears, J. W., \& Spohn, C. C. (1996). The genuine victim and prosecutor's charging decisions in sexual assault cases. American Journal of Criminal Justice, 20(2), 183-205.

Spears, J., \& Spohn, C. (1997). Prosecutors' charging decisions in sexual assault cases. Justice Quarterly, 14, 501-524.

Spohn, C. (2000). Thirty years of sentencing reform: The quest for a racially neutral sentencing process. In Horney, J. (Ed.), Policies, process, \& decisions of the criminal justice system: Criminal justice 2000 (Vol. 3, pp. 427-501). Washington, DC: U.S. Department of Justice.

Spohn, C., Beichner, D., \& Davis-Frenzel, E. (2001). Prosecutorial justifications for sexual assault case rejection: Guarding the "Gateway to Justice." Social Problems, 48 ,206-235.

Spohn, C., Holleran, D. (2000). The imprisonment penalty paid by young, unemployed Black and Hispanic male offenders. Criminology, 38, 281-306.

Spohn, C. \& Horney, J. (1993). Rape law reform: A grassroots revolution and its impact. New York, NY: Plenum Press.

Spohn., C. \& Spears, J. W. (1996). The effect of offender and victim characteristics on sexual assault case processing decisions. Justice Quarterly, 13(4), 649-679.

Spohn, C., \& Tellis, K. (2014). Policing and prosecuting sexual assault: Inside the criminal justice system. Boulder, CO: Lynne Rienner Publishers, Inc. 
Spohn, C., \& Tellis, K. (2019). Sexual assault case outcomes: Disentangling the overlapping decisions of police and prosecutors. Justice Quarterly, 36(3), 383411.

Spohn, C., White, C., \& Tellis, K. (2014). Unfounding sexual assault: Examining the decision to unfound and identifying false reports. Law \& Society Review, 48 (1), 161-192.

Steering Group of the Campbell Collaboration (2019). Campbell systematic reviews: Policies and guidelines. Retrieved from: https://wol-prod cdn.literatumonline.com/pb assets/assets/18911803/Campbell\%20Policies\%20and\%20Guidelines\%20v4.pdf

Steffensmeier, D., Ulmer, J., \& Kramer, J. (1998). The interaction of race, gender, and age in criminal sentencing: The punishment cost of being young, black, and male. Criminology, 36(4), 763-798.

Stemen, D., \& Escobar, G. (2018). Whither the prosecutor? Prosecutor and county effects on guilty plea outcomes in Wisconsin. Justice Quarterly, 35(7), 1166-1194.

Sullivan, G. M., \& Feinn, R. (2012). Using effect size — or why the P value is not enough. Journal of graduate medical education, 4(3), 279-282.

Szumilas M. (2010). Explaining odds ratios. Journal of the Canadian Academy of Child and Adolescent Psychiatry, 19(3), 227-229.

Tasca, M., Rodriguez, N., Spohn, C., \& Koss, M. P. (2013). Police decision making in sexual assault cases: Predictors of suspect identification and arrest. Journal of Interpersonal Violence, 28(6), 1157-1177. 
Tenback, D.E., van Harten, P.N., van Os, J. (2009). Non-therapeutic risk factors for onset of tardive dyskinesia in schizophrenia: A meta-analysis. Movement Disorders, 24, 2309-2315.

Tidmarsh, P., Hamilton, G., \& Sharman, S. J. (2020). Changing Police Officers' Attitudes in Sexual Offense Cases: A 12-Month Follow-Up Study. Criminal justice and behavior, 47(9), 1176-1189.

Tillyer, R. D., \& Hartley, R. D. (2010). Driving racial profiling research forward: Learning lessons from sentencing research. Journal of Criminal Justice, 38, 657665.

Turanovic, J. J., \& Pratt, T. C. (2020). Meta-Analysis in Criminology and Criminal Justice: Challenging the Paradigm and Charting a New Path Forward. Justice Evaluation Journal, 1-27.

Ullman, S. E., \& Filipas, H. H. (2001). Predictors of PTSD symptom severity and social reactions in sexual assault victims. Journal of Traumatic Stress, 14, 369-389.

Ulmer, J. T. (2012). Recent developments and new directions in sentencing research. Justice Quarterly, 29, 1-40.

Van den Noortgate, Wilm, Jose Antonio Lopez-L' opez, Fulgencio M' arin-Martinez, \& Julio Sanchez-Meca. 2013. Three-level meta-analysis of dependent effect sizes. Behavioral Research Methods 45, 576-94.

Venema, R. M., Lorenz, K., \& Sweda, N. (2019). Unfounded, cleared, or cleared by exceptional means: sexual assault case outcomes from 1999 to 2014. Journal of interpersonal violence, Online First, DOI: 0886260519876718. 
Wells, E. (2009). Uses of meta-analysis in criminal justice research: A quantitative review. Justice Quarterly, 26(2), 268-294.

Welsh, B. C., \& Farrington, D. P. (2009). Public area CCTV and crime prevention: An updated systematic review and meta-analysis. Justice Quarterly, 26(4), 716-745.

Weninger, R.A. (1978). Factors affecting the prosecution of rape cases: A case study of Travis County, Texas. Virginia Law Review, 64(3), 357-397.

Wentz, E. A. (2019). Funneled through or filtered out: an examination of police and prosecutorial decision-making in adult sexual assault cases. Violence against women, Online First, DOI: 1077801219890419.

Wentz, E., \& Keimig, K. (2019). Arrest and Referral Decisions in Sexual Assault Cases: The Influence of Police Discretion on Case Attrition. Social Sciences, 8(6), 180.

Wickramasekera, N., Wright, J., Elsey, H., Murray, J., \& Tubeuf, S. (2015). Cost of crime: A systematic review. Journal of Criminal Justice, 43(3), 218-228.

Wilson, D. B., Gottfredson, D. C., \& Najaka, S. S. (2001). School-based prevention of problem behaviors: A meta-analysis. Journal of Quantitative Criminology, 17(3), 247-272.

Wilson, S. J., \& Lipsey, M. (2006). The effects of school-based social information processing interventions on aggressive behavior, part I: Universal Programs. Campbell Systematic Reviews, 2(1), 1-42.

Wolfe, S. E., \& Lawson, S. G. (2020). The organizational justice effect among criminal justice employees: A meta-analysis. Criminology, Online First, DOI:10.1111/1745-9125.12251. 
Wood, D. S., Rosay, A. B., Postle, G., \& TePas, K. (2011). Police presence, isolation, and sexual assault prosecution. Criminal Justice Policy Review, 22(3), 330-349.

Yeaton,W., \&Wortman, P. (1993). On the reliability of meta-analytic reviews: The role of intercoder agreement. Evaluation Review, 17, 292-309.

Ylang, N., \& Holtfreter, K. (2019). The Decision to Arrest in Sexual Assault Case Processing: A Test of Black's Theory of the Behavior of Law. Violence against women, Online First, DOI: 1077801219862632.

Zatz, M. S. (2000). The convergence of race, ethnicity, gender, and class on court decision making: Looking toward the 21st century. Criminal Justice, 3, 503-552. 


\section{APPENDIX A}

Study coding guide

1. Article title

2. Author(s)

3. How was the article located?
a. Database
b. References

4. Study ID \#

5. Exlusion reasoning

6. Journal

7. Reference type
a. Dissertation
b. Journal article
c. Technical report

8. Data source
a. Database
b. Orginal collection

9. Data source (month and year)

10. Sample size

11. Sample composition
a. Percent non-White 
b. Percet White

12. Geographic location(s)

13. Did article exlude male victims?

14. Sample age

15. Did they include only Intimate Partner assaults?

16. Did the exlude unfounded case?

17. Sampling technique

18. Outcome variables

19. Predictor variables

20. Suspect blameworthiness variables

21. Protection of the community variables

22. Practical constraint variables

23. Perceptual shorthand variables

24. Victim credibility variables

25. Multivariate analysis model used 
Risk of bias coding guide (continued)

\begin{tabular}{|c|c|c|c|c|c|c|c|}
\hline Study & date & location & criteria & $\begin{array}{l}\text { Describe } \\
\text { predictor }\end{array}$ & $\begin{array}{l}\text { Describe } \\
\text { outcomes }\end{array}$ & $\begin{array}{l}\text { Specify } \\
\text { model }\end{array}$ & $\begin{array}{l}\text { Report } \\
\text { model } \\
\text { measures }\end{array}$ \\
\hline $\begin{array}{l}\text { Alderden \& } \\
\text { Ullman } \\
(2012 a)\end{array}$ & $\mathrm{Y}$ & $\mathrm{Y}$ & $\mathrm{Y}$ & $\mathrm{Y}$ & $\mathrm{Y}$ & $\mathrm{Y}$ & $\mathrm{Y}$ \\
\hline $\begin{array}{l}\text { Alderden \& } \\
\text { Ullman } \\
\text { (2012b) }\end{array}$ & $\mathrm{Y}$ & Y & Y & $\mathrm{Y}$ & Y & $Y$ & $\mathrm{Y}$ \\
\hline $\begin{array}{l}\text { Beichner \& } \\
\text { Spohn } \\
(2005)\end{array}$ & $\mathrm{Y}$ & $\mathrm{Y}$ & Y & Y & Y & Y & Y \\
\hline $\begin{array}{l}\text { Beichner \& } \\
\text { Spohn } \\
(2012)\end{array}$ & Y & Y & Y & Y & Y & Y & Y \\
\hline $\begin{array}{l}\text { Bouffard } \\
\text { (2000) }\end{array}$ & Y & Y & $\mathrm{N}$ & $\mathrm{Y}$ & Y & $Y$ & $\mathrm{Y}$ \\
\hline $\begin{array}{l}\text { Campbell } \\
\text { (2015) }\end{array}$ & $Y$ & Y & Y & Y & $Y$ & $Y$ & $\mathrm{Y}$ \\
\hline $\begin{array}{l}\text { D'Alessio } \\
\& \\
\text { Stolzenberg }\end{array}$ & $\mathrm{Y}$ & Y & Y & $\mathrm{Y}$ & Y & $Y$ & Y \\
\hline $\begin{array}{l}\text { Du Mont } \\
\text { (1999) }\end{array}$ & $\mathrm{Y}$ & Y & Y & Y & $Y$ & $Y$ & $\mathrm{Y}$ \\
\hline $\begin{array}{l}\text { Holleran et } \\
\text { al. (2010) }\end{array}$ & $\mathrm{Y}$ & Y & Y & $\mathrm{Y}$ & Y & $Y$ & $\mathrm{Y}$ \\
\hline $\begin{array}{l}\text { Horney \& } \\
\text { Spohn } \\
(1996)\end{array}$ & $\mathrm{Y}$ & Y & Y & Y & Y & $Y$ & $\mathrm{Y}$ \\
\hline $\begin{array}{l}\text { Kaiser et } \\
\text { al. (2017) }\end{array}$ & $\mathrm{Y}$ & $\mathrm{Y}$ & Y & Y & Y & Y & Y \\
\hline $\begin{array}{l}\text { Kingsnorth } \\
\text { et al. } \\
\text { (1999) }\end{array}$ & $\mathrm{Y}$ & $\mathrm{Y}$ & $\mathrm{Y}$ & Y & Y & $\mathrm{Y}$ & Y \\
\hline $\begin{array}{l}\text { Morabito et } \\
\text { al. }(2019 b)\end{array}$ & $\mathrm{Y}$ & Y & Y & Y & Y & Y & Y \\
\hline $\begin{array}{l}\text { O'Neal et } \\
\text { al. (2019) }\end{array}$ & Y & Y & Y & Y & Y & Y & Y \\
\hline $\begin{array}{l}\text { Scott \& } \\
\text { Beaman } \\
(2004)\end{array}$ & $\mathrm{Y}$ & $\mathrm{Y}$ & $\mathrm{Y}$ & Y & Y & Y & Y \\
\hline $\begin{array}{l}\text { Smith } \\
(2005)\end{array}$ & $\mathrm{Y}$ & Y & Y & Y & Y & Y & Y \\
\hline
\end{tabular}




\begin{tabular}{|c|c|c|c|c|c|c|c|}
\hline \multicolumn{8}{|c|}{ Risk of bias (continued) } \\
\hline $\begin{array}{l}\text { Spears \& } \\
\text { Spohn } \\
(1996)\end{array}$ & $\mathrm{Y}$ & $Y$ & $\mathrm{Y}$ & $\mathrm{Y}$ & $\mathrm{Y}$ & $\mathrm{Y}$ & $\mathrm{Y}$ \\
\hline $\begin{array}{l}\text { Spears \& } \\
\text { Spohn } \\
(1997)\end{array}$ & $\mathrm{Y}$ & $\mathrm{Y}$ & $\mathrm{Y}$ & $\mathrm{Y}$ & $\mathrm{Y}$ & $\mathrm{Y}$ & $\mathrm{Y}$ \\
\hline $\begin{array}{l}\text { Spohn et al. } \\
\text { (2001) }\end{array}$ & $\mathrm{Y}$ & $\mathrm{Y}$ & $\mathrm{Y}$ & $\mathrm{Y}$ & $\mathrm{Y}$ & $\mathrm{Y}$ & $\mathrm{Y}$ \\
\hline $\begin{array}{l}\text { Spohn \& } \\
\text { Holleran } \\
\text { (2001) }\end{array}$ & $\mathrm{Y}$ & $\mathrm{Y}$ & $\mathrm{Y}$ & $\mathrm{Y}$ & $\mathrm{Y}$ & $Y$ & $\mathrm{Y}$ \\
\hline $\begin{array}{l}\text { Spohn \& } \\
\text { Tellis } \\
\text { (2019) }\end{array}$ & $\mathrm{Y}$ & $Y$ & $\mathrm{Y}$ & $\mathrm{Y}$ & $\mathrm{Y}$ & $\mathrm{Y}$ & $\mathrm{Y}$ \\
\hline $\begin{array}{l}\text { St. George } \\
\text { \& Spohn } \\
\text { (2018) }\end{array}$ & $\mathrm{Y}$ & $Y$ & $\mathrm{Y}$ & $\mathrm{Y}$ & $\mathrm{Y}$ & $\mathrm{Y}$ & $\mathrm{Y}$ \\
\hline $\begin{array}{l}\text { Tasca et al. } \\
\text { (2013) }\end{array}$ & $\mathrm{Y}$ & $Y$ & $\mathrm{~N}$ & $\mathrm{Y}$ & $\mathrm{Y}$ & $\mathrm{Y}$ & $\mathrm{Y}$ \\
\hline $\begin{array}{l}\text { Tellis \& } \\
\text { Spohn } \\
\text { (2008) }\end{array}$ & $\mathrm{Y}$ & $Y$ & $\mathrm{Y}$ & $\mathrm{Y}$ & $\mathrm{Y}$ & $\mathrm{Y}$ & $\mathrm{Y}$ \\
\hline $\begin{array}{l}\text { Wentz } \\
\text { (2014) }\end{array}$ & $\mathrm{Y}$ & $\mathrm{Y}$ & $\mathrm{Y}$ & $\mathrm{Y}$ & $\mathrm{Y}$ & $\mathrm{Y}$ & $\mathrm{Y}$ \\
\hline $\begin{array}{l}\text { Wentz } \\
(2019)\end{array}$ & $\mathrm{Y}$ & $Y$ & $\mathrm{Y}$ & $\mathrm{Y}$ & $\mathrm{Y}$ & $\mathrm{Y}$ & $\mathrm{Y}$ \\
\hline $\begin{array}{l}\text { Wentz \& } \\
\text { Keimig } \\
(2019)\end{array}$ & $\mathrm{Y}$ & $Y$ & $\mathrm{Y}$ & $\mathrm{Y}$ & $\mathrm{Y}$ & $\mathrm{Y}$ & $\mathrm{Y}$ \\
\hline $\begin{array}{l}\text { Wood et al. } \\
\text { (2011) }\end{array}$ & $\mathrm{Y}$ & $Y$ & $\mathrm{Y}$ & $\mathrm{Y}$ & $\mathrm{Y}$ & $\mathrm{Y}$ & $\mathrm{Y}$ \\
\hline $\begin{array}{l}\text { Ylang \& } \\
\text { Holtfreter } \\
\text { (2019) }\end{array}$ & $\mathrm{Y}$ & $Y$ & $\mathrm{~N}$ & $\mathrm{Y}$ & $\mathrm{Y}$ & $\mathrm{Y}$ & $\mathrm{Y}$ \\
\hline
\end{tabular}




\section{CURRICULUM VITA}

David S. Lapsey Jr

\section{CONTACT INFORMATION}

Phone- (502)-445-5687

Email- david.lapsey@louisville.edu

\section{EDUCATION}

May 2021 Ph.D., Criminal Justice, Department of Criminal Justice, University of

Expected Louisville Dissertation: Focal concerns and case advancement in sexual assault cases: A systematic review and meta-analysis

May 2017 M.S., Criminal Justice, Department of Criminal Justice, University of Louisville

May 2015

University
B.A., Criminal Justice and Criminology; Spanish Minor, Indiana Southeast

\section{ACADEMIC POSITIONS}

2017-Present Graduate Research Assistant, Department of Criminal Justice, University of Louisville

\section{RESEARCH AREAS}

Police decision-making

Victimology

Police training

Criminal investigations

Meta-analysis

Prosecutor decision-making

\section{PUBLICATIONS}

Peer-Reviewed Journal Articles

Forth Campbell, B. A., \& Lapsey Jr., D. S. Do impulsivity and education moderate the effectiveness of police sexual assault investigations training? A partially randomized Solomon four-group design. Criminal Justice \& Behavior (Accepted February 2021) 
Forth Lapsey Jr., D. S., Campbell, B. A., \& Plumlee, B. T. Focal concerns and police decision-making in sexual assault cases: A systematic review and meta-analysis. Trauma, Violence, \& Abuse (Accepted January 2021)

Forth Overstreet, S., McNeely, S., Lapsey, Jr., D. S. Can victim offender, and situational characteristics differentiate between lethal and non-lethal incidents of intimate partner violence occurring among adults? Homicide Studies. Link to Article

2020 Campbell, B. A., Lapsey Jr., D. S., \& Wells, W. An evaluation of Kentucky's sexual assault investigator training: Results from a randomized three-group experiment. Journal of Experimental Criminology, 16, 625-647. Link to Article

\section{Manuscripts in progress}

Working Lapsey Jr. D. S. Understanding the focal concerns of prosecutorial decision-making in sexual assault cases: A meta-analytic review. In progress: For submission to the Journal of Interpersonal Violence.

Working Campbell, B. A., \& Lapsey Jr., D. S. Sexual assault investigator training, impulsivity, and the use of procedural justice when interacting with victims: A randomized experiment. In progress: For submission to the Journal of Experimental Criminology.

Working Campbell, B. A., \& Lapsey Jr., D. S. What caused the backlog? Correlates of the decision to submit sexual assault kits for forensic analysis in Kentucky. In progress: For submission to the Journal of Criminal Justice.

\section{GRANTS}

\section{Grant Experience}

2018-Present

Research Assistant

An Evaluation of Victim Centered, Trauma Informed Interview Training for Sexual Assault Investigators using Standardized Patient Actors: A Randomized Controlled Trial. Funded by the National Institute of Justice 2018 Research and Evaluation on Violence Against Women $(\$ 335,13)$.

Supervisor: Bradley A. Campbell, Ph.D. and Rachel Carter, M.F.A.

Duties: Coding interviews, survey development, survey administration, data collection (audio, video, survey), data management in the field, and experiment implementation.

$2017-2020$

Project Manager: 
Kentucky Office of the Attorney General Sexual Assault Kit Initiative (SAKI) Purpose Area 1. Funded by the Bureau of Justice Statistics FY 17 National Sexual Assault Kit Initiative: Comprehensive Approach to Untested Sexual Assault Kits (Total: \$2,998,090; University of Louisville subcontract: 189,831).

Supervisor: Bradley A. Campbell, Ph.D.

Duties: Survey development, survey administration, data entry, merging secondary data with original data, data management, data analysis, technical report writing, and presenting findings to practitioners.

January 2017 - September 2017

Research Assistant:

Sexual Assault Forensic Examination (SAFE) Kit Backlog Research Project: A Statewide Evaluation of Sexual Assault Kit Testing Results, Submission Rates, Case Outcomes, and the Impact of SB 63 on Investigations in Kentucky. Funded by the Kentucky Office of the Attorney General, Office of Victims Advocacy (University of Louisville Award Total: \$49,998.00).

Supervisor: Bradley A. Campbell, Ph.D.

Duties: Survey development, merging secondary data with original data, data entry, data management, technical report writing, and presenting findings to practitioners.

\section{Grant Awarded}

2016 Lapsey Jr., D.S. (PI), Campbell, B.A. (Faculty Supervisor) Louisville Metro Police Department Homicide Investigation Project. University of Louisville, Graduate Student Thesis Grants for Research and Creative Activities in the College of Arts and Sciences (\$811.00).

\section{TECHNICAL REPORTS}

2018 Campbell, B. A., \& Lapsey, D. S. SAFE kit submission to the KSP Forensic Laboratory: An analysis of trends before and after DANY/SB63. Solicited report for the Kentucky SAFE Kit Backlog Research Project Working Group (15 pages).

2018 Campbell, B. A., \& Lapsey Jr., D.S. An evaluation of the Kentucky DOCJT Sexual Assault Investigator Training Program: Results from a Solomon fourgroup design. Solicited report for the Kentucky SAFE Kit Backlog Research Project Working Group (30 pages).

2018 Lapsey Jr., D.S., Simpkins, B., Braden, V. Louisville Metro Police Department Real 
Louisville

Crime Center: Evaluation and Recommendations. Solicited Presentation to

Metro Police Real Time Crime Center and Louisville Metro Police Department (28 pages).

2018 Lapsey, D. S., \& Campbell, B. A. Kentucky sexual assault responder training: Results and recommendations from DOCJT and KY OAG trainings. Solicited report prepared for the Kentucky SAFE Kit Backlog Working Group (14 pages).

2018 Campbell, B.A., \& Lapsey Jr., D.S. Post CODIS-hit victim engagement: Review of the literature and data collection recommendations. Solicited report prepared for the Kentucky SAFE Kit Backlog Working Group (12 pages).

2017 Campbell, B.A., \& Lapsey Jr., D.S. LMPD SVU Preliminary Results from DANY Untested Cases and Notification Efforts: Analysis of LMPD and KSP Lab Data up to December 5, 2017 (19 pages).

\section{CONFERENCE PRESENTATIONS}

2019 Campbell, B.A. \& Lapsey Jr., D.S. The impact of self-control and training on police perceptions of victims: Results from a partially randomized experiment. American Society of Criminology. San Francisco, CA. November.

2019 Lapsey Jr., D.S. \& Campbell, B. A. What caused the backlog? Correlates of the decision to submit sexual assault kits for forensic analysis in Kentucky. American Society of Criminology. San Francisco, CA. November.

2019 Lapsey Jr., D. S. \& Campbell, B. A. Impact of training, impulsivity, and charge perceptions on decisions in hypothetical sexual assault cases: Evidence from a randomized study. Midwestern Criminal Justice Association: Chicago, IL. September.

2018 Overstreet, S., McNeely, S., \& Lapsey Jr., D.S. Can victim, offender, and situational characteristics differentiate between lethal and non-lethal intimate partner violence? American Society of Criminology: Atlanta, GA. November.

2018 Lapsey Jr., D. S. \& Campbell, B. A. The impact of statewide reform on the submission and testing of sexual assault kits. American Society of Criminology: Atlanta, GA. November.

2018 Campbell, B. A. \& Lapsey Jr., D. S. An evaluation of statewide sexual assault investigator training: Results from a Solomon four-group design. American Society of Criminology: Atlanta, GA. November.

2017 Campbell, B.A. \& Lapsey Jr., D.S. Cold case training - from investigation to convictions: Prosecuting sexual assault cold cases. Lexington, KY. June. 
2016 Lapsey Jr., D.S. Colombian law enforcement Conference: Managing media and police relations: Louisville, KY. April.

\section{INVITED PRESENTATIONS}

2019 Lapsey Jr., D.S. \& Aldridge, C. Strategies for Success and Sustainability. Solicited Presentation to the $4^{\text {th }}$ Annual National Sexual Assault Kit Initiative (SAKI) Grantees Meeting, Arlington, VA. June.

2018 Lapsey Jr., D.S., Simpkins, B., \& Braden, V. Louisville Metro Police Department Real Louisville

Crime Center: Evaluation and Recommendations. Solicited Presentation to

Metro Police Real Time Crime Center and Louisville Metro Police Department, Louisville, KY. April.

2018 Program Evaluation of the Living Room Program. Solicited Presentation to Louisville Metro Police Department, Louisville Department of Corrections, and Centerstone Mental Health Services, Louisville, KY. April.

2017 Campbell, B.A. \& Lapsey Jr., D.S. Kentucky SAFE Kit Backlog Research Project: SART-AC Research Update on Preliminary Findings. Solicited Presentation to the Kentucky Sexual Assault Response Team Advisory Committee, Frankfort, KY. October.

\section{TEACHING}

Undergraduate Course Taught (University of Louisville)

Police and the Community (Fall, 2019)

\section{Undergraduate Course Prepped (University of Louisville)}

Police in the United States

\section{PROFESSIONAL DEVELOPMENT}

Bureau of Justice Assistance's Researcher Practitioner Partnerships Fellows Academy (40 hours). February 2018.

Federal Bureau of Investigation's ViCAP Kentucky Regional Training (16 hours). June 2019.

Forensic Interview Trauma Interview (FETI) Kentucky Regional Training (8 hours). May 2018. 


\section{PROFESIONAL ORGANIZATION SERVICES}

2019 Registration Table for the Midwestern Criminal Justice Association (MCJA) Chicago, IL (University of Louisville).

2018 Registration Table for the Midwestern Criminal Justice Association (MCJA) Chicago, IL (University of Louisville).

\section{ACADEMIC REFERENCES}

\section{Bradley Campbell}

Assistant Professor

Department of Criminal Justice

Research Associate, Southern Police

Institute

University of Louisville

2311 South Third Street, 223 Brigman

Hall

Louisville, Kentucky 40208

(502) 852-4763

Bradley.campbell@ louisville.edu

\section{Gennaro F. Vito}

Professor

Department of Criminal Justice

Program Faculty, Southern Police

Institute

University of Louisville

2311 South Third Street, 203 Brigman

Hall

Louisville, Kentucky 40208

(502) 852-6509

Gennaro.vito@louisville.edu

\section{George Higgins}

Professor

Department of Criminal Justice

University of Louisville

2311 South Third Street, 208 Brigman

Hall

Louisville, Kentucky 40208

(502) 852-0331

George.higgins@louisville.edu 